\title{
arI
}

$00 \div 101999$

\section{Ecological Effects of Pipeline Construction through Deciduous Forested Wetlands, Midland County, Michigan}

Interim Report

(August 1988-August 1990)

GRL-91/0045

Gas Research Institute

Environment \& Safety Research Department

July 1991 


\section{ECOLOGICAL EFFECTS OF PIPELINE CONSTRUCTION THROUGH DECIDUOUS FORESTED WETLANDS, MIDLAND COUNTY, MICHIGAN}

\title{
INTERIM REPORT
}

(August 1988-August 1990)

Prepared by

\author{
S.D. Zellmer, J.R. Rastorfer, ${ }^{*}$ and G.D. Van Dyke* \\ Reclamation Engineering and Geosciences Section \\ Energy Systems Division \\ Argonne National Laboratory (ANL) \\ 9700 South Cass Avenue \\ Argonne, rllinois 60439
}

For

GAS RESEARCH INSTITUTE

Contract No. 5088-252-1770

GRI Project Manager

H. Ronald Isaacson

Environment \& Safety Research Department

July 1991

${ }^{*}$ Rastorfer is associated with the Department of Biological Scieı ces, Chicago State University (CSU), Chicago, and the ANL/CSU Cooperative Herbarium, and Van Dyke is associated with the Department of Biology, Trinity Christian College, Palos Heights, Illinois.

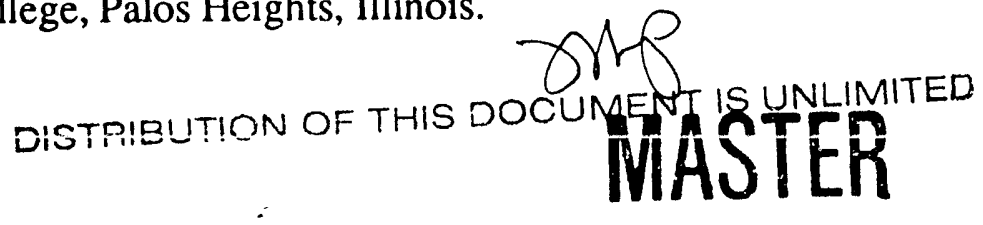


Legal Notice. This report was prepared by Argonne National Laboratory as an account of work sponsored by the Gas Research Institute (GRI). Neither GRI, members of GRI, nor any person acting on behalf of either:

a. Makes any warranty or representation, express or implied, with respect to the accuracy, completeness, or usefulness of the information contained in this report, or that the use of any apparatus, method, or process disclosed in this report may not infringe privately owned rights; or

b. Assumes any liability with respect to the use of, or for damages resulting from the use of, any information, apparatus, method, or process disclosed in this report.

\section{DISCLAIMER}

This report was prepared as an account of work sponsored by an agency of the United States Government. Neither the United States Government nor any agency thereof, nor any of their employees, makes any warranty, express or implied, or assumes any legal liability or responsibility for the accuracy, completeness, or usefulness of any information, apparatus, product, or process disclosed, or represents that its use would not infringe privately owned rights. Reference herein to any specific commercial product, process, or service by trade name, trademark, manufacturer, or otherwise does not necessarily constitute or imply its endorsement, recommendation, or favoring by the United States Government or any agency thereof. The views and opinions of authors expressed herein do not necessarily state or reflect those of the United States Government or any agency thereof. 


\title{
Research Summary
}

\author{
Title \\ Contractur \\ Principal Investigators \\ Report Period \\ Objective \\ Technical Perspective \\ Ecological Effects of Pipeline Construction through Deciduous \\ Forested Wetlands, Midland County, Michigan \\ Report Period \\ Technical Perspective \\ Argonne National Laboratory \\ GRI Contract Number 5082-254-0690 \\ J.R. Rastorfer and G.D. Van Dyke

\section{August 1988-August 1990} \\ To document temporal and spacial aspects of both positive and \\ negative impacts on vegetation resulting from the establishment \\ of a pipeline right-of-way (ROW) through deciduous forested \\ wetlands in east central Michigan. \\ New federal regulations, which are being considered but not yet \\ implemented and are designed to protect wetlands, make \\ information on both positive and negative impacts of gas \\ pipeline ROWs on wetlands essential for the gas pipeline \\ industry. This study is designed to document the temporal and \\ spacial extent of positive and negative effects on vegetation \\ resulting from the establishment and maintenance of a pipeline \\ ROW through deciduous forested wetlands in east central \\ Michigan. Such information will facilitate the permitting process \\ and may suggest modifications in installation and maintenance \\ practices to mitigate negative impacts.
}

Results
All results at this time are preliminary, because a study such as this must be long term to properly measure effects that may take years or decades to develop. Observations made during data collections indicate that damage was done to the forest edge beyond the ROW at one of the two study sites during construction, when logs from the clearing operation were pushed into the forest edge rather than being removed from the site. Plant species established from the seed mixture that was applied to the ROW after construction reduced the wetland characteristic of the vegetation developing on the ROW during the first year following pipeline construction. Tree stumps that had not interfered with construction operations and had remained in place on the ROW allowed small adjacent reservoirs of native understorv species to survive. The minimal amount of time between ditching and backfilling allowed vegetative propagules of native species to survive on the ROW and in the pipe-ditch 
Technical Approach

Project Implications soil. Hand seeding of the ROW in wetland areas without complete tillage also contributed to survival of native species.

Two sites were selected for this study on the basis of the presence of wetland soils, vegetation, and other characteristics. One site is in a relatively mature, second-growth forest; the other is in a second-growth forest with the same soil type, but it shows evidence of selective logging in the recent past. Belt transects, parallel to the ROW, were established on the ROW and in the forested wetland at preselected distances from the edge of the ROW. Understory and ROW vegetation were and continue to be measured using coverage estimates for each species within forty $1 \times 1-\mathrm{m}$ quadrats within each of seven $1 \times$ 100-m belt transects at each site (for a total of 280 quadrats). Counts of individuals by species are being made for all woody plants with stems $<2 \mathrm{~cm}$ in diameter at breast height (dbh). Stem diameters and species counts are being recorded for all woody plants with stems $\geq 2 \mathrm{~cm}$ dbh in $10 \times 10-\mathrm{m}$ plots constituting three $10 \times 100-\mathrm{m}$ belt transects in the forested portion of each site. Two years of data have been collected at each site, and a third and a fourth year of data will be collected during the 1991 and 1992 growing seasons. Then analyses of the data will be performed, and a final first-phase report will be prepared during the two subsequent years.

Information of the type provided by this study will be increasingly required during the permitting process for future pipeline construction through forested wetlands. Information that suggests ways (1) to minimize both the extent and duration of negative impacts on adjacent wetland communities, (2) to facilitate reestablishment of wetland vegetation on the ROW, and (3) to enhance beneficial aspects with respect to the habitats of wildlife and endangered species, can facilitate the permitting process. These data will also be of value in selecting maintenance practices that enhance the wetland value of the ROW.

GRI Project Manager

H. Ronald Isaacson

Environment \& Safety Research Department 


\begin{tabular}{|c|c|c|}
\hline $\begin{array}{l}\text { REPORT DOCUMENTATION } \\
\text { PAGE }\end{array}$ & $\begin{array}{r}\text { 1. REPORT NO. } \\
\text { GRI-91/0045 }\end{array}$ & 3. Reciplent's Accession No. \\
\hline \multirow{2}{*}{\multicolumn{2}{|c|}{$\begin{array}{l}\text { 4itlo ond Subtite } \\
\text { Ecological Effects of Pipeline Construction through Deciduous } \\
\text { Forested Wetlands, Midland County, Michigan }\end{array}$}} & \begin{tabular}{|l|} 
5. Roport Date \\
July 1991 \\
\end{tabular} \\
\hline & & 6. \\
\hline \multicolumn{2}{|c|}{$\begin{array}{l}\text { 7. Author(s) } \\
\text { Stanley D. Zellmer, James R. Rastorfer, and Gerrit D. Van Dyke }\end{array}$} & 8. Pertorming Orgenlzation Ropt. No. \\
\hline \multirow{2}{*}{\multicolumn{2}{|c|}{$\begin{array}{l}\text { 9. Portorming Organization Name and Addrass } \\
\text { Reclamation Engineering and Geosciences Section } \\
\text { Energy Systems Division } \\
\text { Argonne Nationa1 Laboratory } \\
9700 \text { South Cass Avenue } \\
\text { Argonne, Illinois } 60439-4815\end{array}$}} & $\begin{array}{l}\text { 10. Project/Tosk/Work Unit No. } \\
\text { ACK } 85062\end{array}$ \\
\hline & & $\begin{array}{l}\text { 11. Contract(C) or Grant(G) No. } \\
\text { (C) } 5088-252-1770 \\
\text { (G) }\end{array}$ \\
\hline \multirow{2}{*}{\multicolumn{2}{|c|}{$\begin{array}{l}\text { 12. Sponsoring Organization Name and Address } \\
\text { Gas Research Institute } \\
8600 \text { West Bryn Mawr Avenue } \\
\text { Chicago, Illinois } 60631\end{array}$}} & 13. Type of Report \& Period Covered \\
\hline & & 14. \\
\hline
\end{tabular}

15. Supplementary Notes

16. Abstract (Limit: 200 words)

Implementation of recent federal and state regulations promulgated to protect wetlands makes information on effects of gas pipeline rights-of-way (ROWs) in wetlands essential to the gas pipeline industry. This study is designed to record vegetational changes induced by the construction of a large-diameter gas pipeline through deciduous forested wetlands. Two second-growth forested wetland sites mapped as Lenawee soils, one mature and one subjected to recent selective logging, were selected in Midland County, Michigan. Changes in the adjacent forest and successional development on the ROW are being documented. Cover-class estimates are being made for understory and ROW plant species using $1 \times 1-\mathrm{m}$ quadrats. Counts are also being made for all woody species with stems $<2 \mathrm{~cm}$ in diameter at breast height $(\mathrm{dbh})$ in the same plots used for cover-class estimates. Individual stem diameters and species counts are being recorded for all woody understory and overstory plants with stems $\geq 2 \mathrm{~cm}$ dbh in $10 \times 10$-m plots. Although analyses of the data have not been completed, preliminary analyses indicate that some destruction of vegetation at the ROW forest edge may have been avoidable during pipeline construction. Rapid regrowth of many native wetland plant species on the ROW occurred because remnants of native vegetation and soil-bearing propagules of existing species survived on the ROW after pipeline construction and seeding operations.

\begin{tabular}{ll}
\hline 17. Document Analysis : Descriptors & \\
Rights-of-Way & Succession \\
Vascular Plants & Bryophytes \\
Species Inventory & Cover Class
\end{tabular}

b. Identifiers/Open-Endod Torms

c. CosATI Field/Group

\begin{tabular}{|c|c|c|}
\hline 18. Avallability Statement & $\begin{array}{l}\text { 19. Securlty Class (This Report) } \\
\text { Unclassif ied }\end{array}$ & 21. No. of Pages \\
\hline & $\begin{array}{l}\text { 20. Socurity Class (This Page) } \\
\text { Unclassified }\end{array}$ & 22. Price \\
\hline
\end{tabular}




\section{Preface}

The research described in this report was performed by the Reclamation Engineering and Geosciences Section of Argonne National Laboratory's Energy Systems Division as part of the Right-of-Way Research Program sponsored by the Gas Research Institute. This multiyear, multidisciplinary research effort began in 1983 in response to an assessment study of the environmental concerns of 20 natural gas transmission companies. Study results indicated a lack of quantitative research data demonstrating the effectiveness of right-of-way rehabilitation following pipeline construction. The study also established that little research had been conducted to evaluate the recovery of both natural and managed ecosystems or to determine cost-effective right-of-way management practices to ensure effective habitat rehabilitation on rights-of-way.

The major goal of the Right-of-Way Research Program is to reduce the environmental and economic costs associated with the installation and maintenance of natural gas pipelines. The program has an established committee of industry representatives who assist in formulating program objectives to achieve three goals:

- Quantitative documentation of industry pipeline-construction methods and rightof-way reclamation practices,

- Development of a data base to evaluate the environmental effects of pipeline construction and right-of-way reclamation methods, and

- Development and testing of technologies that minimize costs and mitigate negative environmental effects of pipeline construction.

Several Right-of-Way Research Program studies are being conducted to determine the impacts of current or past pipeline construction methods on wetlands. This study is designed to determine the ecological effects of pipeline construction through deciduous forested wetlands in the east-central part of the lower peninsula of Michigan. This interim report describes the two study sites, the data collection methods, and the initial observations of and suggestions for pipeline construction through forested wetlands. Preliminary data analyses indicate both sites met the established criteria for deciduous forested wetlands. Information from this study will provide the natural gas pipeline industry with quantitative data on the ecological effects of a typical pipeline construction project through forested wetlands in the upper Midwest. These data can be used to predict the effects of pipeline construction through forested wetlands in areas with similar vegetative communities, soils, and climatic conditions. Observations from this study can also be used to mitigate negative ecological impacts of pipeline construction through comparable forested wetlands.

Donald O. Johnson, Manager

Right-of-Way Research Program 


\section{Acknowledgments}

This study, Ecological Effects of Pipeline Construction through Deciduous Forested Wetlands, Midland County, Michigan, was made possible only because of the cooperation and contributions of a number of individuals and organizations. Mr. B.J. Haskins and the State of Michigan, Department of Natural Resources, granted permission for the study to be conducted on their properties and have allowed vegetation and soil samples to be collected at the sites. Mr. C.L. Conley, Area Forest Manager of the Gladwin Field Office, provided background information on the Michigan State site (Site 2). We extend special thanks and recognition to these individuals and the State of Michigan, Department of Natural Resources.

Dr. J.J. Rochow, Staff Environmental Scientist with Consumers Power Company, was instrumental in initiating the study and locating the study sites and has acted as liaison between Midland Cogeneration Venture Limited Partnership (the pipeline owner) and Argonne National Laboratory (ANL). We are indebted to Dr. Rochow, his staff and associates, and both companies for their assistance.

The Gas Research Institute is gratefully ackr: wledged for providing funding for this research effort. Dr. H.R. Isaacson, project manager, has furnished guidance and support, and we especially appreciate his interest and assistance.

Several students have provided assistance during the study. James E. Frelichowski (1989 and 1990) and Matthew Solcum (1989) were summer research participants at ANL. Dwight E. Huslin (January-June 1989) and Jay A. Clemente (September 1990-present) have assisted in the ANL-Chicago State University (CSU) Cooperative Herbarium. Kee Beom Lee (graduate -October 1989-May 1990) and Erika Green (undergraduate -- September 1990-present) have been CSU Department of Biological Sciences student assistants. We appreciate the efforts of all these students. 


\section{Contents}

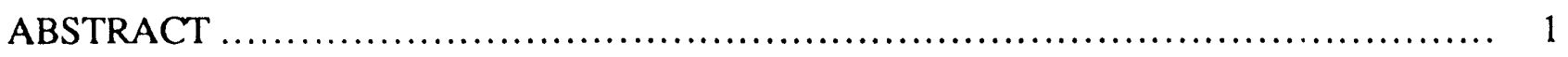

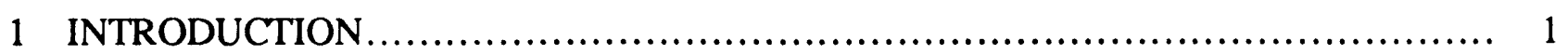

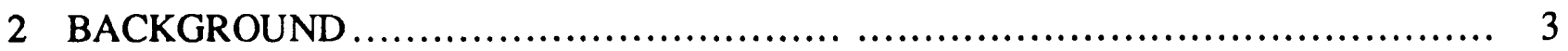

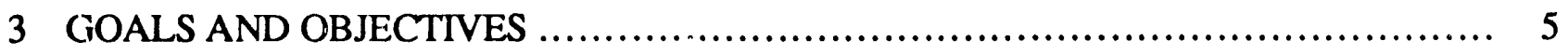

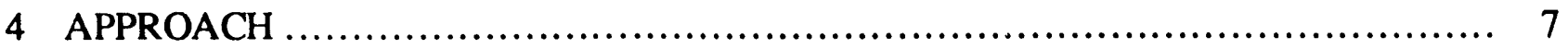

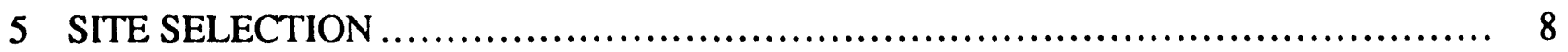

6 AREA DESCRIPTION ........................................................... 12

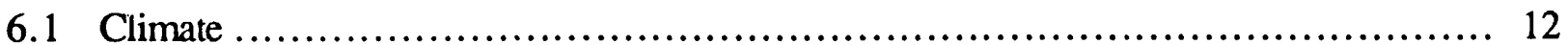

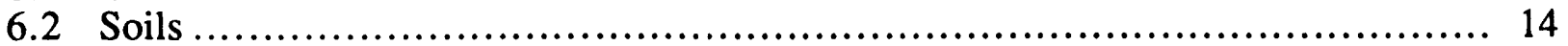

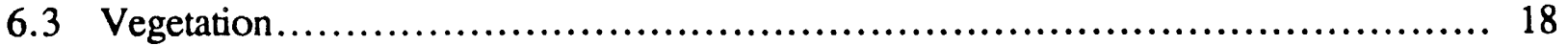

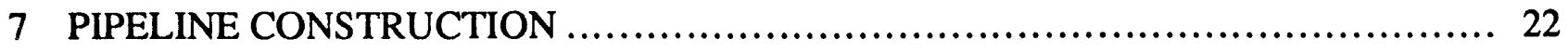

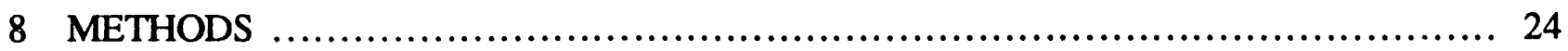

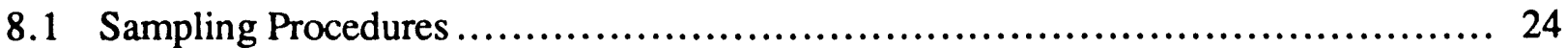

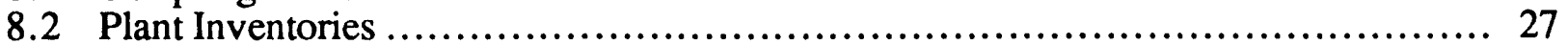

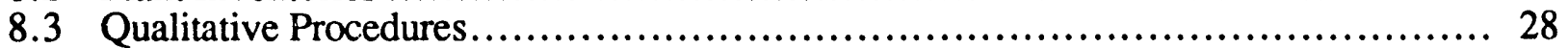

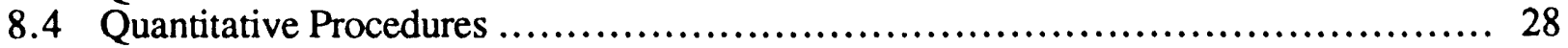

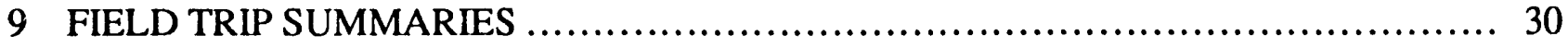

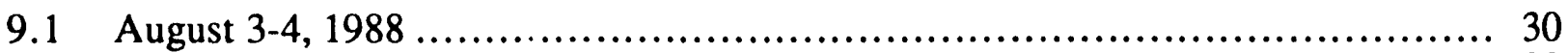

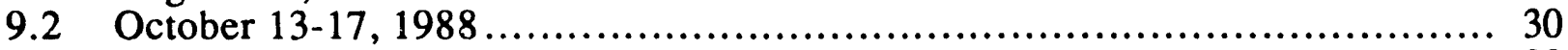

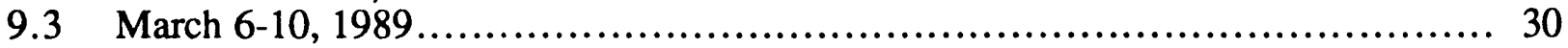

9.4 April 11-16, 1989................................................................ 31

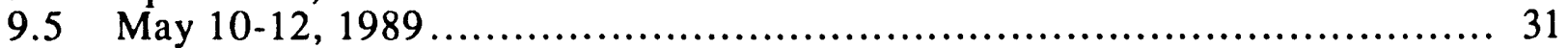

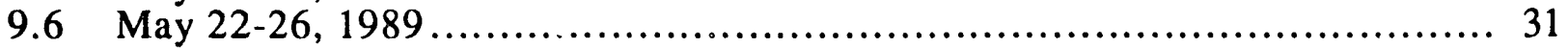

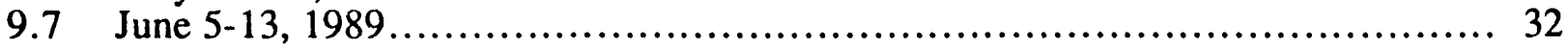

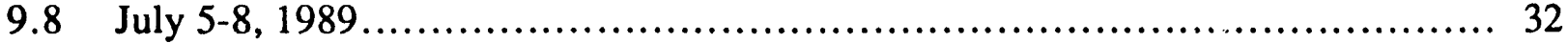

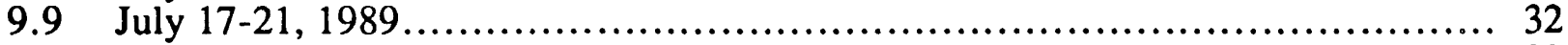

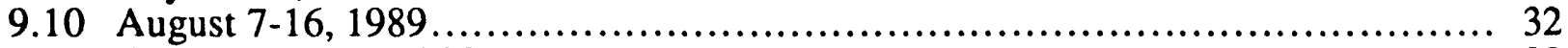

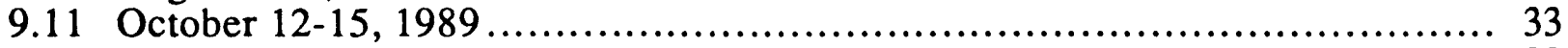

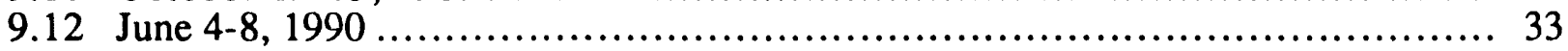

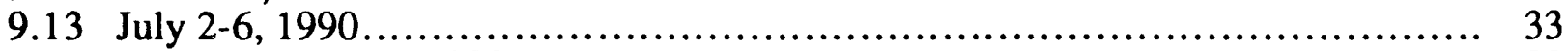

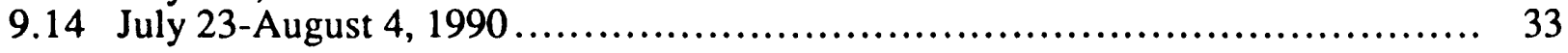

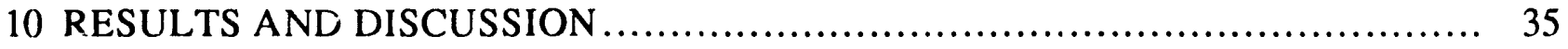

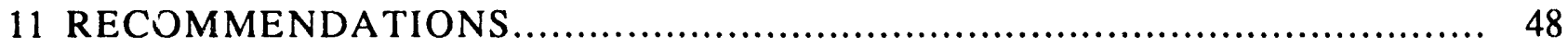

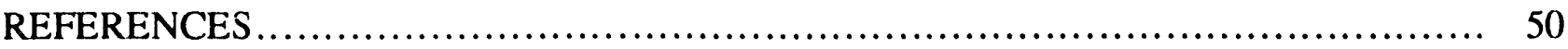




\section{Contents (Cont'd)}

APPENDIX A Description of the Typical Pedon for Lenawee Silty Clay Loam in Midland County............................................... 57

APPENDIX B Selected Vascular Plants in Lower Michigan .......................... 59

APPENDIX C Woody Plants in Missaukee County...................................... 61

APPENDIX D Field Data Sheet Used to Record Cover-Class Numbers and Selected Shoot Counts for Understory Taxa .................................... 63

APPENDIX E Field Data Sheet Used to Record Stem Diameters for Overstory Taxa ...... 65

APPENDIX F Field Data Sheet Used to Map Overstory Taxa........................... 67

APPENDIX G Coordinates and Numbers for $10 \times 10$-Meter Plots Used to Analyze Overstory Taxa.......................................................... 69

APPENDIX H Taxon Data Sheet Used to Keep Records on Voucher Specimens.......... 71

APPENDIX I Vascular Plants in Midland County ...................................... 73

APPENDIX J Cover-Class Values and Frame Used in Cover Estimation Sampling ....... 87

APPENDIX K Sample Data Collected and Calculated for Sensitive Fern.................... 89

\section{Figures}

1 Locations of Sites 1 and 2 in Section 25 of Greendale Township, Midland County........ 9

2 March 1989 Photograph Showing Typical Forest Characteristics of Site 1 ............. 10

3 March 1989 Photograph Showing Typical Forest Characteristics of Site 2 .............. 10

4 Physiogeograpl.ic Regional Subdivisions of Michigan's Lower Peninsula ............... 13

5 Generalized Relief Features of Michigan's Lower Peninsula............................... 14

6 Major Forest and Soil Regions of Michigan's Lower Peninsula........................ 15

7 Three Midcontinental Glacial Lakes .............................................. 16

8 Soil Map of Section 25 of Greendale Township, Midland County ...................... 17

9 Vegetation Map Depicting the Original Forests of Michigan's Lower Peninsula............. 20 


\section{Figures (Cont'd)}

10 Sectional Drawing Typifying the Physiognomy of Sites 1 and 2:

Adjacent Forest, Right-of-Way, and Unimproved Gordonville Road.

11 Positions of Understory Transects, Right-of-Way Transects, and Overstory Plots for Both Sites.

\section{Tables}

1 Number of Species in the Forested and Right-of-Way Portions of Sites 1 and 2, by Indicator Category

2 Provisional List of Plants Found at Sites 1 and 2 and Surrounding Areas, Midland County, October 1988-October 1989

3 Provisional List of Plants Found on the Right-of-W/ay, Midland County, July 1989-August 1990 


\title{
Ecological Effects of Pipeline Construction through Deciouous Forested Wetlands, Midland County, Michigan
}

\author{
Interim Report \\ (August 1988-August 1990)
}

\author{
by \\ Stanley D. Zellmer, James R. Rastorfer, and Gerrit D. Van Dyke
}

\begin{abstract}
Implementation of recent federal and state regulations promulgated to protect wetlands makes information on effects of gas pipeline rights-of-way (ROWs) in wetiands essential to the gas pipeline industry. This study is designed to record vegetational changes induced by the construction of a large-diameter gas pipeline through deciduous forested wetlands. Two second-growth forested wetland sites mapped as Lenawee soils, one mature and one subjecied to recent selective logging, were selected in Midland County, Michigan. Changes in the adjacent forest and successional development on the ROW are being documented. Cover-class estimates are being made for understory and ROW plant species using $1 \times 1-\mathrm{m}$ quadrats. Counts are also being made for all woody species with stems $<2 \mathrm{~cm}$ in diameter at breast height (dbh) in the same plots used for cover-class estimates. Individual stem diameters and species counts are being recorded for all woody understory and overstory plants with stems $\geq 2 \mathrm{~cm}$ dbh in $10 \times 10-\mathrm{m}$ plots. Although analyses of the data have not been completed, preliminary analyses indicate that some destruction of forest vegetation at the forest edge may have been avoidable during pipeline construction. Rapid regrowth of many native wetland plant species on the ROW occurred because remnants of native vegetation and soil-bearing propagules of existing species survived on the ROW after pipeline construction and seeding operations.
\end{abstract}

\section{Introduction}

The installation of a large-diameter pipeline through a forest -- a process that involves the clear cutting of the right-of-way (ROW), trenching, backfilling, grading, and seeding operations -- removes or destroys essentially all of the aboveground plant biomass. Trenching and backfilling alter the chemical and physical properties of the soil in the pipe ditch (Zellmer and Taylor 1988). Subsequently, secondary vegetational development (succession) occurs on the ROW, until stabilized yet dynamic treeless plant communities (an anthropogenic disclimax or arrested succession) develop as a consequence of ROW maintenance practices (Niering and 
Goodwin 1974). Furthermore, the clearing of the forest from the ROW alters the light, wind, temperature, and microclimatic factors within the new forest edge from those in the forest interior (Ranney et al. 1981). The development of vegetation on the ROW results in the formation of zones of integration called ecotones (Daubenmire 1968; Spurr and Barnes 1973), where the plant communities of the ROW confront the plant communities of the adjacent forest. Little information is available on the temporal and spatial aspects of these ecotones.

Quantitative data on the temporal and spatial aspects of the edge effects within the forest, the temporal development of the anthropogenic disclimax on the ROW, and the temporal and spatial aspects of the development of ecotones within the forest edge are important to the gaspipeline industry. Such information is essential to provide answers to questions raised by federal, state, and local regulatory agencies responsible for the construction permitting process. Data related to forested wetlands (for a definition, see Cowardin et al. 1979) are increasingly important, as impending federal and existing state regulations concerning wetland piotection (Federal Interagency Committee for Wetland Delineation 1989; Michigan Department of Natural Resources 1988a, 1988b) are enforced. The iust.nce of such data slows down the permitting process and adversely affects construction sr'.edules for new gas transmission pipelines.

This study is intended to provide the gas pipeline industry with information on both the negative and beneficial aspects of vegetational changes on and adjacent to pipeline ROWs through northern broad-leaved deciduous forested wetlands. It is designed to provide answers to questions such as these:

- What type of plant communities develop on the ROW?

- If wetland communities should develop on the ROW after construction, how soon will they meet wetland vegetational criteria?

- What vegetational changes, if any, occur within the forest edge adjacent to the ROW?

- What plant species, if any, are likely to be lost from the forest edge?

- What new plant species, if any, invade the forest edge?

- How far do vegetational changes within the forest edge extend into the forest?

- Will the wetland status of the forest edge be affected with respect to vegetation?

Answers to these questions will not only facilitate the permitting process but may suggest possible modifications in pipeline installation and maintenance practices to minimize the negative impacts and maximize the beneficial aspects of ROWs through northern broad-leaved deciduous forested wetlands. 


\section{Background}

This review of vegetational and related ROW studies is primarily concerned with ROWs for underground natural gas transmission pipelines (GPLs). However, essentially no vegetational studies on GPL ROWs have been done from a long-term ecological point of view. In contrast, ROWs for aboveground electrical transmission lines (ETLs) have received considerable attention (Byrnes and Holt 1987; Crabtree 1984; Tillman 1976, 1981). Thereforc, any of these studies that are relevant to this investigation are covered in this brief review. Although noteworthy vegetational studies have been done for highway and railroad ROWs (Byrnes and Holt 1987; Crabtree 1984; Tillman 1976, 1981), they are not considered here because roadways are sufficiently different, with respect to design and postconstructicn usage, to warrant separate consideration.

Four aspects of GPL ROW installations as they affect vegetation are discussed:

1. The initial clearing of the vegetation,

2. The effects on soil properties,

3. The postconstruction establishment and development of "egetation, and

4. The composition of stable plant communities maintained by cyclic maintenance practices.

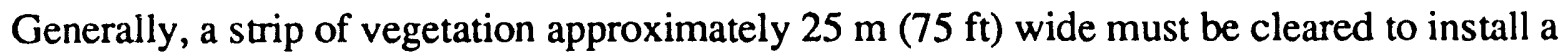
large-diameter ( $\geq 38 \mathrm{~cm}$ or $15 \mathrm{in}$.) GPL. Clearing essentially devastates the existing aboveground plant biomass by removing or mechanically damaging it. Moreover, most of the aboveground plant vestiges that might have remained after the clearing operations disappear during trenching, pipeline installation, backfilling, and any associated grading activities. In effect, the end result of the GPL installation operations is a strip of highly disturbed land that is often laid bare (Arner 1966; Egler 1954; Zellmer and Taylor 1988). Furthermore, the soil is affected by the GPL construction operations. In some situations, vehicular equipment compacts soils on the working side of the ROW (Steinhardt et al. 1987). Trenching (especially the single-ditching method), backfilling, and grading operations mix the soil horizons and result in pipe-ditch soils (the column of soil over the buried pipeline) without soil profiles. The upper layers of soil on either side of the pipe ditch may be also be disturbed by trenching, backfilling, and associated grading operations. Hence the chemical and physical properties of the soils are altered, and soil erosion rates in hilly areas can be accelerated as a result of pipeline construction activities (Arner 1966; de Jong and Button 1973; Taylor et al. 1987; Zellmer and Taylor 1988; Zellmer et al. 1987). The consequence of GPL installation activities, which decimate aboveground vegetation and alter soil characteristics, is the production of highly disturbed and/or barren ROWs. Under most climatic conditions, vascular and nonvascular plants become established on new GPL ROWs, except in cases where edaphic factors have changed beyond plant tolerances or soil erosion rates are too high for plants to survive. 
The taxonomic composition and structural features of plant communities that develop on highly disturbed or bare GPL ROWs are usually determined by the native vegetation that is reestablished and by the seed mixtures that are applied during the closing GPL construction activities. Native plants result from the preexisting and surrounding vegetation and the soil propagule bank; the presence of regenerative roots, rhizomes, stems, and stumps; and the immigration of seeds, spores, and gemmae (Brown 1987; Harper 1977; Hutnik et al. 1987). Although operational seeding of introduced species has been a common practice on GPL ROWs, recent reports indicate that under most environmental situations, either natural revegetation or the use of native plant species is considered the most ecologically sound approach to establishing vegetation on highly disturbed and bare GPL ROWs (Downey 1976; Farnworth 1981; Johnson 1984; Long and Ellis 1984; Odegard et al. 1984).

The development of vegetation to stabilized yet dynamic anthropogenic disclimax communities on GPL ROWs depends on preexisting and surrounding floristic elements, GPL installation activities, and maintenance practices. For GPL LOWs, stable nonwoody plant communities are usually desired, because they allow the ROW to be inspected more easily and allow the heavy, mechanized equipment needed to repair buried pipelines to move more freely. Nonwoody vegetation is aiso desirable because these herbaceous plants become readily discolored from pipeline leaks and can be detected by aerial inspections (Arner 1960; Egler 1954).

In treeless ecosystems such as marshes, natural revegetation occurs rapidly after carefully planned GPL installation operations. Hence, GPL ROWs in such ecosystems generally require no maintenance to eliminate woody taxa (Farnworth 1981; Krone et al. 1987; Odegard et al. 1984). Forest ecosystems, on the other hand, do require maintenance to exclude woody plants. Unfortunately, the number of ecological studies on the methods used to achieve stable, herbaceous-dominant communities on GPL ROWs within forested (and shrub) habitats (compared with those on ETL ROWs) is few (Byrnes and Holt 1987; Crabtree 1984; Nickerson and Thibodeau 1986; Niering et al. 1986; Niering and Goodwin 1974; Thibodeau and Nickerson 1986; Tillman 1976, 1981). Mowing and herbicide applications are commonly used to maintain herbaceous communities on GPL ROWs. However, studies on ETL ROWs and, to a lesser extent, GPL ROWs indicate that burning, when applicable, is an economically and ecologically effective method of eliminating woody plants from ROWs (Arner 1960, 1981; Arner et al. 1976, 1987; Huntley and Arner 1984; Olson et al. 1984).

With respect to this study, adequate information is not available to enable the prediction of the successional stages of vegetational development on the ROW segments to stable, nonwoody communities (anthropogenic disclimax herbaceous communities). Therefore, vegetational development must be monitored on the ROW and the forest edge until a stable anthropogenic disclimax, as determined by the maintenance method and cycle, is reached. After the 1992 field season, monitoring at four- or five-year intervals over the next 10,20 , or more years will probably be required for the plant communities on the ROW segments to become stable enough so that results can be obtained on the interactions of ROW plant communities and adjacent forest communities (Magnuson 1990). 


\section{Goals and Objectives}

The overall intent of several studies in the Right-of-Way Research Program is to determine the impacts of current or past pipeline construction methods on wetlands. This study has three major goals, and several objectives have been designed to meet each of these goals. The goals and objectives are as follows:

1. Document any vegetational changes that occur in the forested wetlands adjacent to the ROW at the study sites.

a. Characterize and monitor the vegetation in the forested wetlands away from the ROW as a reference control and to document changes not induced by the ROW.

b. Document new species invading the edge of the forested wetlands that might have resulted from the presence of the ROW and maintenance practices.

c. Document the loss of species from the edge of the forested wetlands that might have resulted from the presence of the ROW and maintenance practices.

d. Document changes in species abundance at the edge of the forested wetlands that might have resulted from the presence of the ROW and maintenance practices.

2. Document vegetational succession on the ROW, from the time the pipeline is installed until stable, managed (anthropogenic disclimax) plant communities develop.

a. Document the initial, or pioneer, stages of vegetational succession on the ROW to aid in determining wetland characteristics and effects of and necessity for seeding operations.

b. Document later successional stages and the more or less stable anthropogenic disclimax community that has formed under the maintenance regime, to determine its effects on wetland characteristics.

3. Provide insights and suggestions on lessening the ecological impacts of future pipeline installation operations on forested wetlands.

a. Suggest modifications in construction practices that will ensure that the ROWs through forested wetlands remain wetlands. 
b. Suggest installation and maintenance practices that will maximize the beneficial aspects of the diversified habitat.

c. Suggest installation and maintenance practices that will minimize negative impacts in terms of both temporal and spatial changes.

d. Consider site installation and maintenance practices in terms of their effects on successional trends and wetland benefits. 


\section{Approach}

Locations of construction projects for new, underground, large-diameter, gas transmission lines in the north-central region of the United States were reviewed, and inquiries were made with respect to the possible participation of one or more pipeline companies. After a suitable construction project was located, the proposed route of the ROW was inspected, and potential ecologic study sites within the forested wetlands were identified. The criteria used to select study sites were (1) vegetational homogenity, (2) level topography, (3) a single soil series, and (4) a water table near the soil surface. Two sites were selected, and necessary legal agreements among Argonne National Laboratory, the pipeline owner (Midland Cogeneration Venture Limited Partnership), and each site owner (Billy J. Haskins and Michigan's Department of Natural Resources, State Forest Land) were secured.

This investigation is designed to analyze the compositional and structural changes that occur in forested communities adjacent to the ROW as a result of the installation of the gas pipeline and the maintenance of the ROW. Also of interest are the compositional and structural changes that occur during the serial development of plant communities on the ROW itself. To analyze these features of plant communities, data are being taken of the understory taxa in $1 \times 1-\mathrm{m}$ $(3.28 \times 3.28-\mathrm{ft})$ plots along permanent transects and the overstory taxa in permanent $10 \times 10-\mathrm{m}$ $(32.8 \times 32.8-\mathrm{ft})$ plots. The understory transects are located both on the ROW and in the forest at selected intervals from the ROW, from adjacent to the ROW to a distance considered beyond its influence. In contrast, the overstory plots are located only in the forest at selected intervals from the ROW, from adjacent to the ROW to a distance considered beyond its influence. Data collection began immediately after installation of the pipeline and will continue seasonally (summers) through the fourth growing season. After the fourth growing season, sampling will be repeated every four to five years, until two or more samplings substantiate stable anthropogenic disclimax plant communities on the ROW.

In addition to vegetational sampling, a taxonomic inventory is being taken, with voucher specimens of the plant species that occur on the sites and immediate surrounding areas. This taxonomic inventory is necessary not only to facilitate identification of species during data collection but also to evaluate the sites with respect to the invasion of new species, the loss of preROW species, and the assessment of wetland vegetational components. The analysis of field data will provide ecological information on dominance, diversity, and frequency to aid in determining compositional changes at the species level and compositional and structural changes at the community level. 


\section{Site Selection}

As the result of a collaborative effort, personnel at the Gas Research Institute (GRI), Consumers Power Company (CP), and Argonne National Laboratory (ANL) determined that a route proposed for the construction of a large-diameter pipeline ( $26 \mathrm{in}$. or $66 \mathrm{~cm}$ ) by the Midland Cogeneration Venture Limited Partnership in the east-central portion of Michigan's lover peninsula could be a potential location for plant ecologic studies. The construction of the G/PL, under the direction of CP, in 1989 began east of Shepherd in Isabella County and ended near Midland in Midland County. Because the route of the GPL crossed both farm and poorly drained forested lands, the resulting ROW and adjacent areas would provide suitable sites in deciduous forested wetlands for the proposed wetland study.

With respect to the ROW and adjacent forest plant community studies, two investigators from ANL met with two representatives from CP (the supervisor of its Environmental Department and its ROW agent) on August 3 and 4,1988, to tour portions of the proposed ROW and identify potential study sites. Three sites at different locations in Midland County were evaluated.

The group decided that the forest stand that was inspected first would be most suitable for studying how lowland forest ecology is affected by the construction of a gas pipeline. The study site is in the southern half of the southeast quarter of Section 25, T. 14N, R. 2W, in Greendale Township, Midland County, Michigan (Fig. 1). It is next to and north of an unimproved section of Gordonville Road (1.61 km or 1 mile from Castor Road on the east to an unimproved section of Magrudder Road on the west). This site had the best qualifications because (1) it was an advanced second-growth stand of hardwood deciduous forest trees with an apparent high degree of homogeneity in the understory layers, (2) it contained some hydric plant taxa, (3) it had nearly level topography, (4) it had seemingly little edaphic variation, and (5) there was no evidence of recent logging or any other major disturbance. In addition, the land was considered to be in a trust, and a review of the relationship between the trustee and CP indicated that there would be no problem in securing permission to conduct ecologic studies on this property.

After the August trip, ANL arranged for legal agreements with the landowner, Mr. Billy J. Haskins. At that time, ANL learned that because of an exchange of property between Mr. Haskins and the Michigan Department of Natural Resources, the parcel of forested land contracted for the study was not located at the site selected during the August 1988 field trip. During a field trip on October 13-17, 1988, the actual contracted parcel owned by Mr. Haskins was located. A stand of deciduous forest in an area mapped as Lenawee silty clay loam soil (Hutchison 1979) was identified on Mr. Haskin's property and designated as Site 1. It is about 1450 meters (4690 ft) west of the junction of Gordonville and Castor Roads and north of the unimproved Gordonville Road. Also during this field trip, preliminary vegetational studies were made, and similarities and differences between this site and the other site selected during the August field trip were noted (Figs. 2 and 3). Although the soil, topography, and relative position of the two sites with respect to unimproved Gordonville Road are essentially the same, the vegetation of Site 1 differs structurally from that at Site 2 . Site 1 has a younger population of trees and a thicker shrubby 


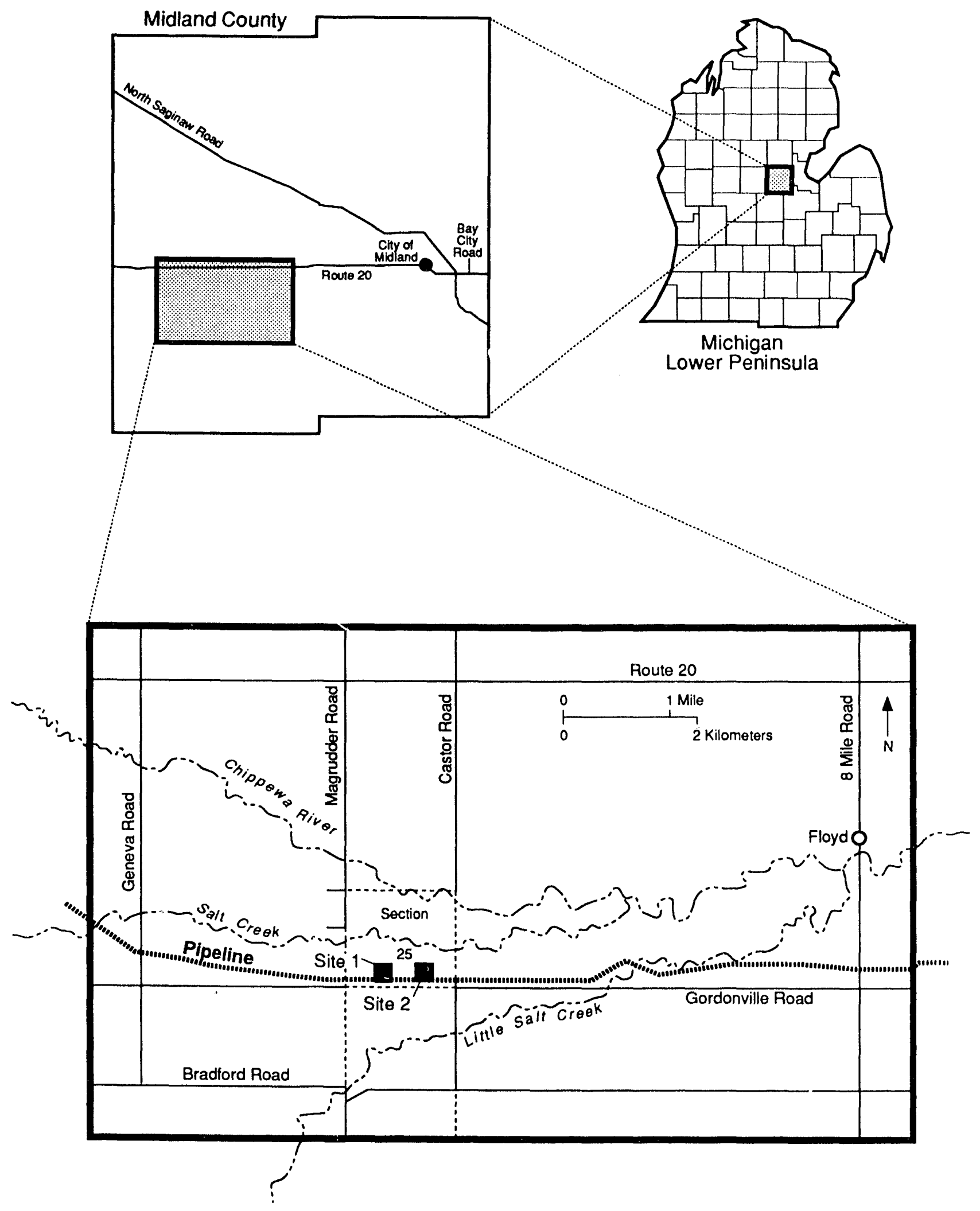

FIGURE 1 Locations of Sites 1 and 2 in Section 25 of Greendale Township, Midland County 


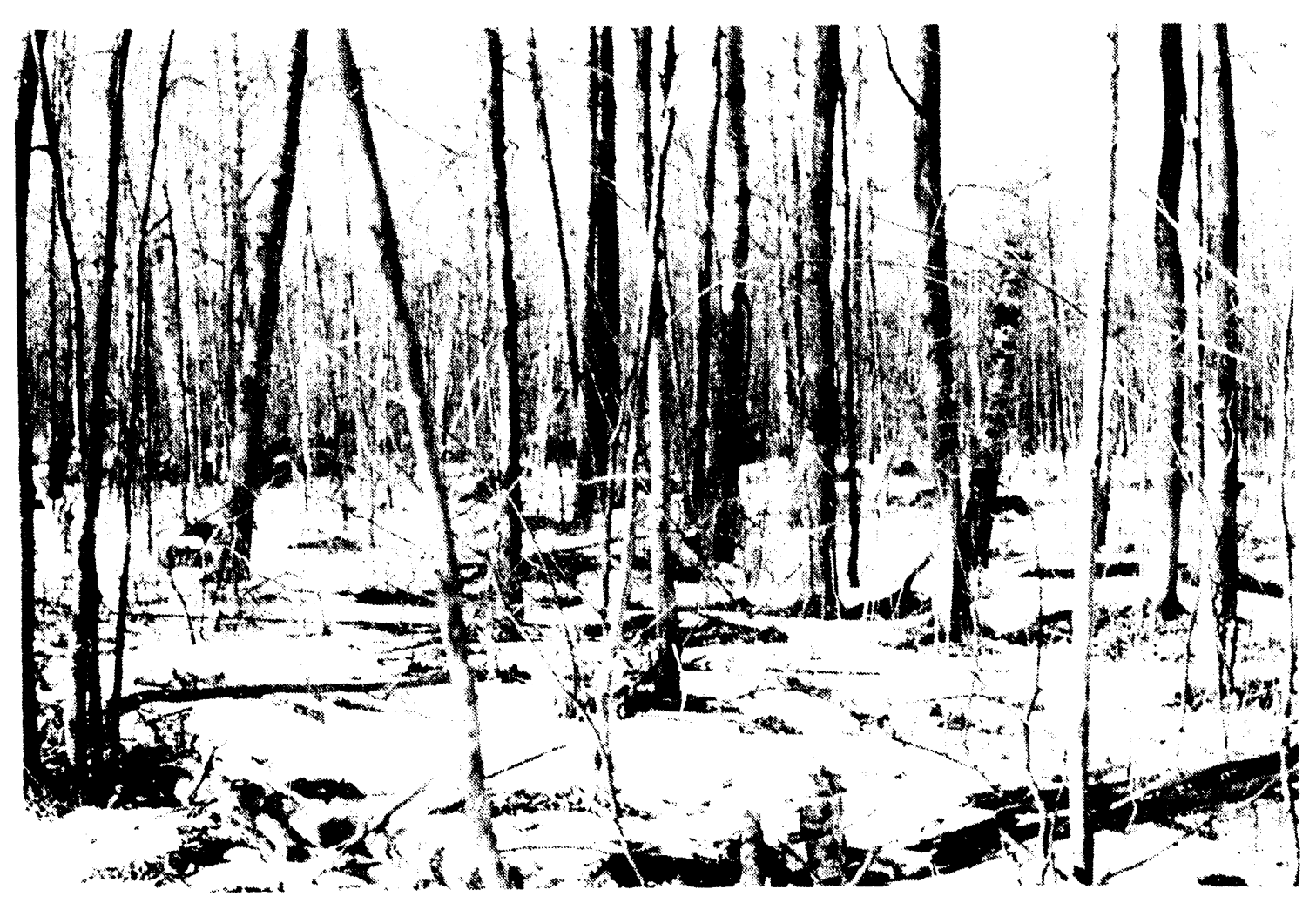

FIGURE 2 March 1989 Photograph Showing Typical Forest Characteristics of Site 1

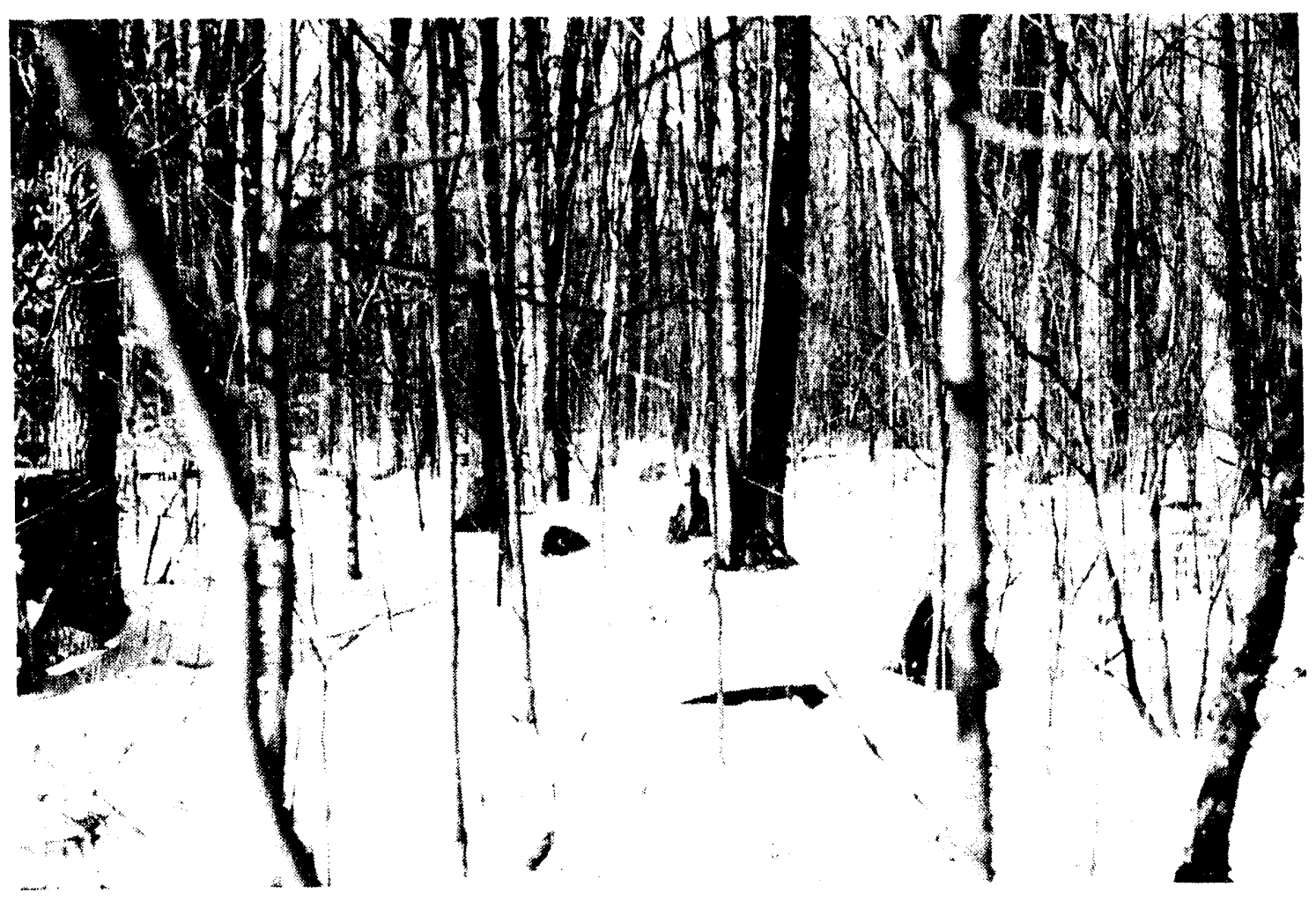

FIGURE 3 March 1989 Photograph Showing Typical Forest Characteristics of Site 2 
understory, and the herbaceous layers seem to be more heterogeneous at Site 1. These observations and the presence of relatively new stumps indicate that Site 1 had been recently disturbed by selective logging.

Following the October field trip, the vegetation at Site 1 (Mr. Haskin's property) was reevaluated with respect to the more mature vegetation at the other original site, now known to be on Michigan state forest land. This evaluation generated the idea of using both sites to conduct concurrent studies comparing the effects of GPL construction on a recently selectively logged forested wetland and a more mature forested wetland. Such a comparison may provide information on the responses of two different successional stages of forested wetlands. Following discussions with colleagues and approvals by appropriate institutions, ANL secured legal permission to conduct studies in the stand of Michigan state forest land, which was designated as Site 2 . 


\section{Area Description}

Midland County is in the Saginaw Lowland, one of the six physical regional subdivisions in the southern peninsula of Michigan recognized by Veatch (1953) (also see Albert, Deaton, and Barnes 1986). Saginaw Lowland is composed mostly of lake beds and has an elevation of less than $200 \mathrm{ft}$ above Lake Huron (Fig. 4). Topographically, Midland County is flat to undulating, with a low relief (Fig. 5). The total area of flat surfaces greatly exceeds the total area of slopes. The slopes generally have a low gradient; if they are steep, the slope is short and ranges from 0-6\% (Hutchison 1979). Midland County's flatness is a manifestation of its geological history, which is briefly reviewed in the soils section that follows the section on climate.

\subsection{Climate}

Midland County has a temperate continental climate, which is essentially uniform throughout the county (Brunnschweiler 1964; Eichmeier 1964; Hutchison 1979; Strommen 1974). The average daily temperature in summer is $20.8^{\circ} \mathrm{C}\left(69.5^{\circ} \mathrm{F}\right)$, and the average daily temperature in winter is $-3.8^{\circ} \mathrm{C}\left(25.1^{\circ} \mathrm{F}\right)$. In summer, the average daily maximum temperature is $27.1^{\circ} \mathrm{C}\left(80.8^{\circ} \mathrm{F}\right)$, with the highest average monthly temperature in July, at $22.4^{\circ} \mathrm{C}\left(72.4^{\circ} \mathrm{F}\right)$. In winter, the average daily minimum temperature is only $-7.8^{\circ} \mathrm{C}\left(17.9^{\circ} \mathrm{F}\right)$, with the lowest average monthly temperature in January and February, at $-4.0^{\circ} \mathrm{C}\left(24.8^{\circ} \mathrm{F}\right)$. The hottest temperature recorded was $41.1^{\circ} \mathrm{C}\left(106^{\circ} \mathrm{F}\right)$ on July 24,1934 . The coldest temperature recorded was $-34.4^{\circ} \mathrm{C}\left(-30^{\circ} \mathrm{F}\right)$ on February $10,1912$. Temperatures recorded at Midland for the period 1930-1974 indicate that in five of ten years, there will probably be 150 days on which the daily minimum temperature will be higher than $0^{\circ} \mathrm{C}\left(32^{\circ} \mathrm{F}\right)$. Also, in five of ten years, the first freeze date $\left(0^{\circ} \mathrm{C}, 32^{\circ} \mathrm{F}\right.$, or lower $)$ is likely to be October 6 or earlier and the last freeze date, May 8 or later (Hutchison 1979).

Precipitation in Midland County is relatively uniform throughout the year, ranging from monthly averages of $40 \mathrm{~mm}$ (1.57 in.) during the winter to $80 \mathrm{~mm}$ (3.13 in.) during the summer. The county has a total average annual precipitation of $744 \mathrm{~mm}(29.3 \mathrm{in}),. 58 \%$ of which falls during the major portion of the growing season, April through September. Annual average precipitation in the form of snow is $970 \mathrm{~mm}$ (38.2 in.); however, the maximum depth at any single time during the period of record (1946-1975) was $711 \mathrm{~mm}$ (28.0 in.). Standard relative humidity measurements have not been recorded at Midland, Michigan; however, data have been recorded at Lansing, Michigan, located about $80.5 \mathrm{~km}$ (50 miles) south of the city of Midland. The highest yearly average relative humidity is $84 \%$ at 7:00 a.m., and the lowest yearly average relative humidity is $62 \%$ at 1:00 p.m. The highest monthly average is $92 \%$ in September at 7:00 a.m.; the lowest monthly average is $48 \%$ in June at 1:00 p.m. Data recorded at Lansing show that the prevailing wind is from the southwest, with the highest average daily wind speeds ranging from 19.3-20.1 km (12.0-12.5 miles) per hour for January through April. The lowest average daily wind speeds range from 14.0-15.4 km (8.7-9.6 miles) per hour for June through August.

Although Midland County and the remainder of the state have a continental climate, Michigan differs somewhat climatically from its neighboring midcontinental states because its two 


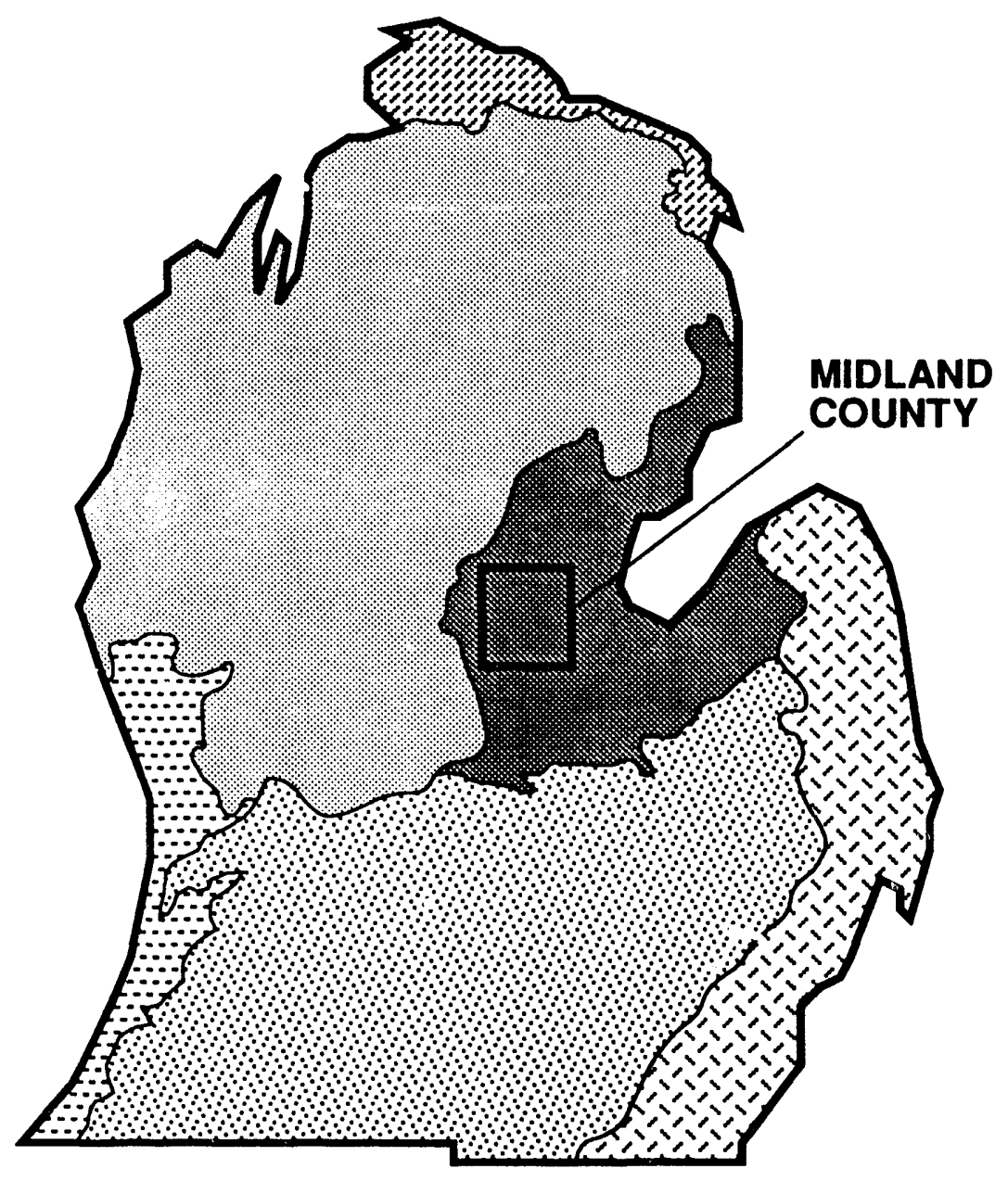

Exig Cheboygan Lowland

Northern Upland

Saginaw Lowland

E:- Lake Michigan Lowland Plains

Southern Upland

$\square$ Huron Erie Lowland Plains

FIGURE 4 Physiogeographic Regional Subdivisions of Michigan's Lower Peninsula (Adapted from Veatch 1953)

peninsular portions are each surrounded on three sides by members of the Great Lakes. Because the lakes have a stabilizing effect on temperature, the winters are milder and the summers are generally cooler in Michigan than they are at the same latitudes in Wisconsin and Minnesota (Eichmeier 1964; Seeley 1964; Strommen 1974). In Michigan's lower peninsula, the latitude, topography, temperature, and precipitation patterns since the last continental glaciation have produced two climatic regions -- a cooler and drier northern region and a relatively warmer and wetter southern region -- with a climatic swing zone across the central portion of the peninsula from the Saginaw Bay area westward. The interaction of climatic factors with parent materials of soil and developing vegetation has likewise manifested itself in two edapho-vegetational regions and a transition zone (Fig. 6). These edaphic and floristic features of Midland County are considered in the next sections. 


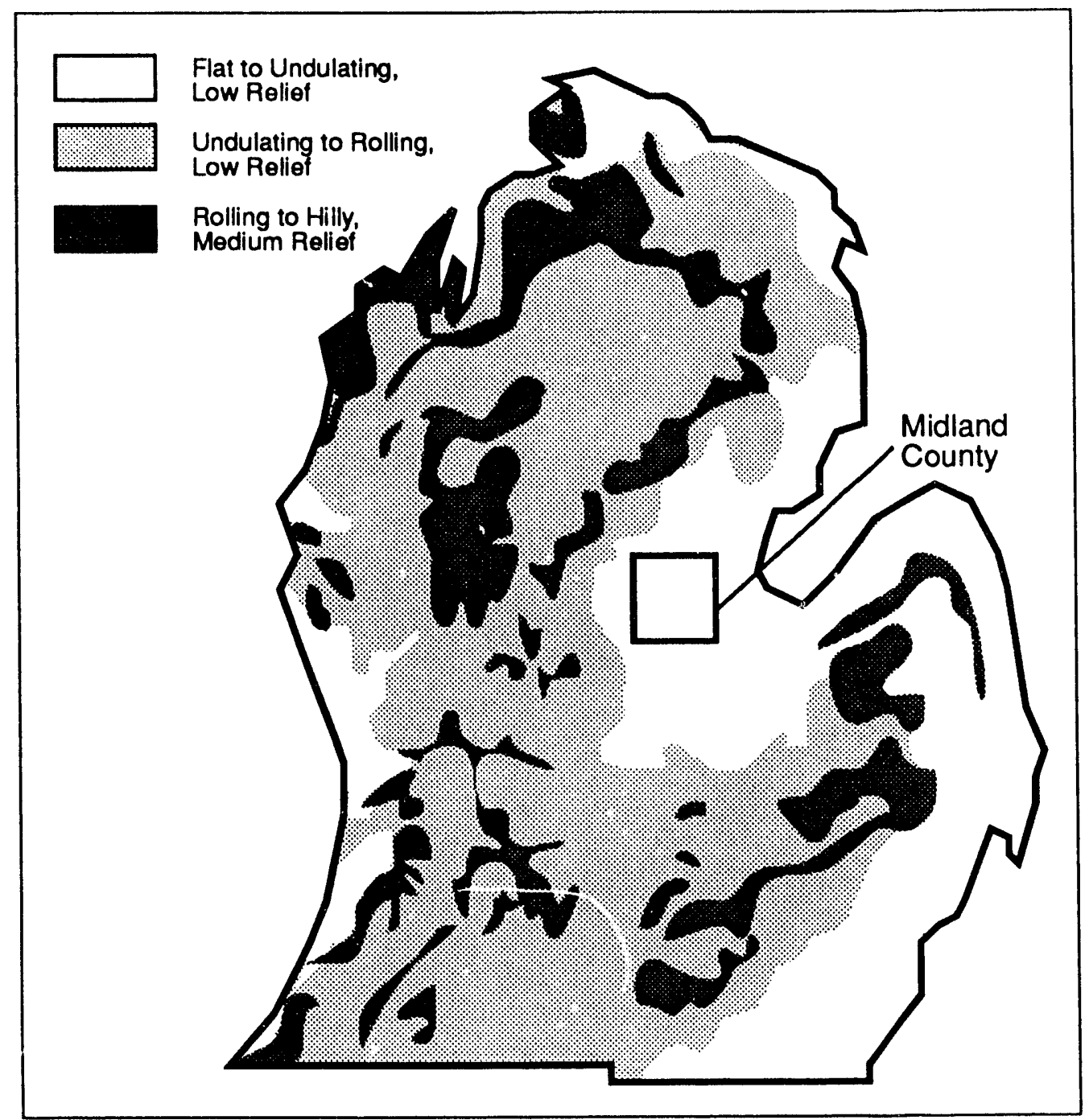

FIGURE 5 Generalized Relief (Topographical) Features of Michigan's Lower Peninsula (Adapted from Veatch 1953)

\subsection{Soils}

Soil genesis in Midland County was initiated on different deposits resulting from glacial activities (Dorr and Eschman 1970; Farrand 1988; Kelly 1964; Martin 1958, 1964). Glacial till overlays Pennsylvanian bedrock. Other parent materials consisting of lacustrine, outwash, alluvium, and dead aquatic plant materials deposited over the glacial till during the maximum and subsequent diminishing stages of glacial Lake Saginaw, 10,000-12,000 years ago (Fig. 7). Following their deposition, some of these materials were reworked and redeposited by the actions of wind and water. Except for some recent alluvial deposits, soils in Midland County are mature and have distinct horizons (Hutchison 1979; Miller 1964; Veatch 1953). 


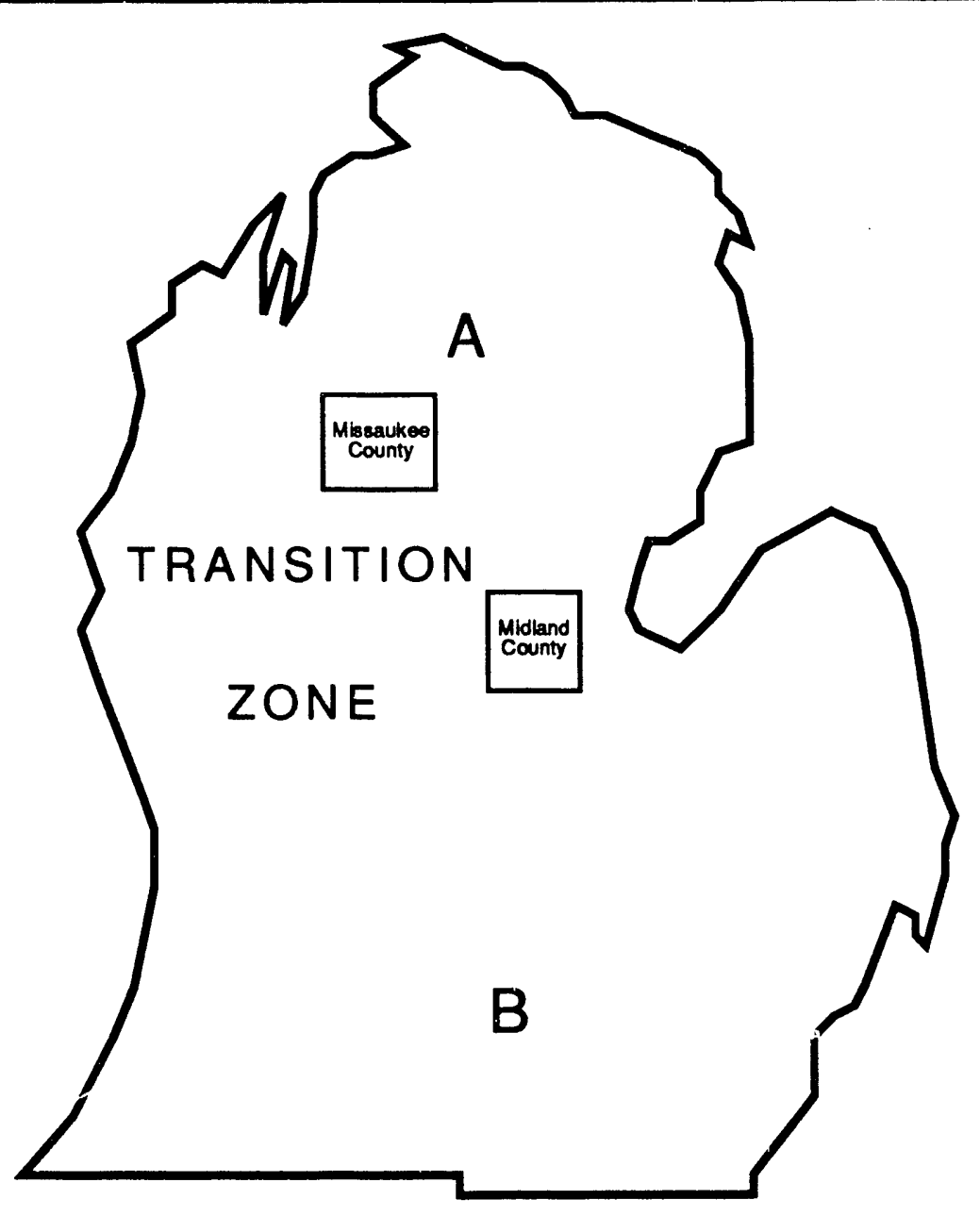

A Podzol Soil (= Spodosol) Region and the Northern Hemlock-White Pine-Northern Hardwoods Forest Region

B Gray-Brown Podzolic Soil (= Alfisol) Region and Beech-Maple Forest Region

FIGURE 6 Major Forest and Soil Regions of Michigan's Lower Peninsula (Adapted from Braun 1974 and Veatch 1953) 


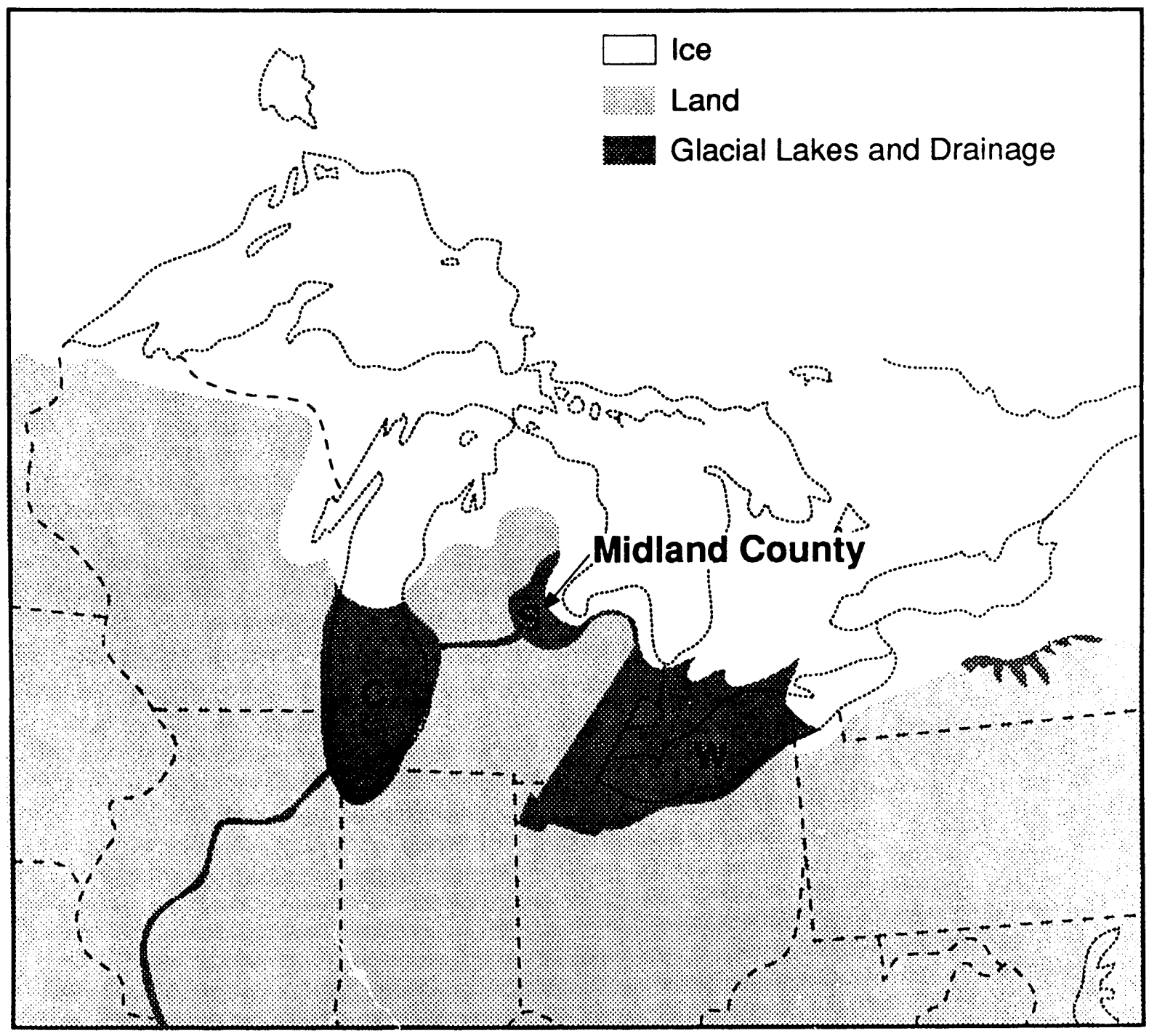

FIGURE 7 Three Midcontinental Glacial Lakes. $C=$ Lake Chicago, $S=$ Lake Saginaw, and W = Lake Whittlsey (Adapted from Dorr and Eschman 1970)

Midland County has seven major soil associations based on parent materials, textural compositions, topographic features, and drainage patterns (Hutchison 1979). In Greendale Township (location of the study sites), the major soil association is designated KingsvillePipestone-Covert. The soils of this association are characterized as being nearly level to gently sloping and poorly to moderately well drained. These soils also have a sandy subsoil or upper substratum in outwash or glacial lake deposits. Interwoven among the soil units of this association are soil units of other associations. Both study sites have been mapped as the Lenawee silty clay loam (fine, mixed, nonacid, mesic Mollic Haplaquods) by Hutchison (1979), one of the interweaving soils that is a component of the Lenawee-Bower-Wixom association (Fig. 8). The soils of this association are characterized as being nearly level to gently sloping and very poorly to somewhat poorly drained. They have either a loamy and clayey subsoil or a sandy and loamy subsoil and were formed in glaciolacustrine and till deposits (Hutchison 1979; Martin 1958). 
Ch Cohoctah fine sandy loam, gravelly substratum

CoB Covert sand, $0-6 \%$ slopes

CsB Covert sand, loamy substratum, $0-6 \%$ slopes

$\mathrm{Kg}$ Kingsville loamy fine sand
Le Lenawee silty clay loam

PsB Pipestone sand, 0-3\% slopes

PtB Pipestone sand, loamy substratum $0-3 \%$ slopes

Sz Sloan loam

Wa Wauseon sandy loam

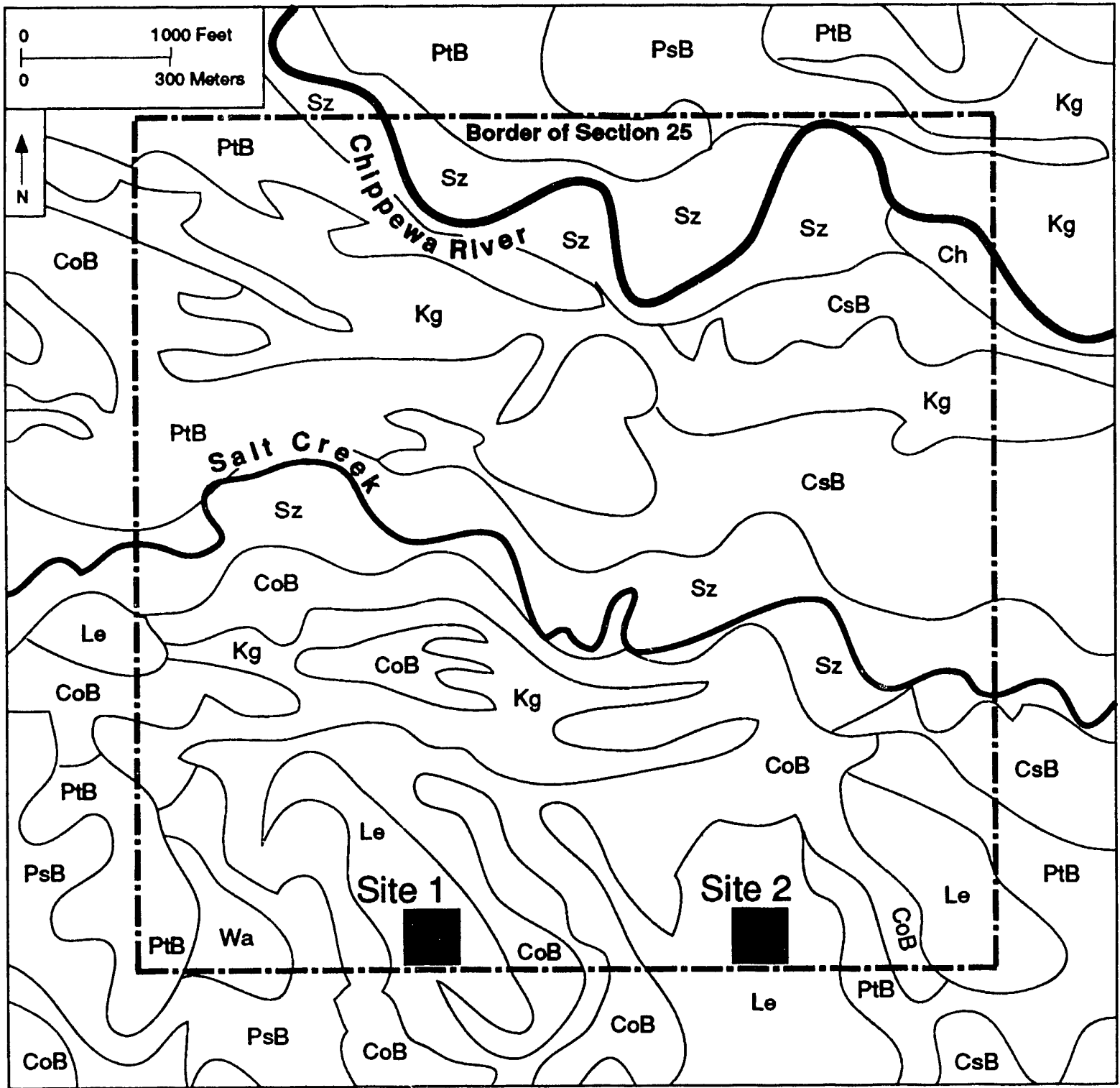

FIGURE 8 Soil Map of Section 25 of Greendale Township, Midland County. Sites 1 and 2 are located on Lenawee soils (Adapted from Hutchison 1979) 
Lenawee soils were formed in clay or loam lacustrine deposits with $0-2 \%$ slopes that comprise broad flat areas and drainage ways. These soils are characterized as being moderately slowly permeable, poorly or very poorly drained, and subject to frequent flooding. The surface layer is typically a black silty clay loam about $22.9 \mathrm{~cm}$ (9 in.) thick. The mottled subsoil is about $78.7 \mathrm{~cm}$ (31 in.) thick, and its upper part consists of a dark grayish brown, firm silty clay loam; its middle is a light brownish gray, firm silty clay; and its lower part is a grayish brown, very firm silty clay (Hutchison 1979). Additional pedologic features of the Lenawee soil (under cultivation) are described in App. A. A particularly important characteristic of Lenawee soils with respect to this study is that they are considered hydric soils (USDA, Soil Conservation Service 1987).

In addition to parent materials and relief (topography), climate is an important factor in the development of soils. Although climatic differences probably did not have significant effects on the maturation of different soils within Midland County, the county is in a part of the lower peninsula that was, and apparently still is, subject to climatic tension. Here the cooler climatic elements of northern Michigan intermix with the warmer climatic elements of southern Michigan. This area across the central portion of the lower peninsula is considered a climatic transition zone or tension zone (Fig. 6) that supports transition soils (Veatch 1953). These transition soils undoubtedly represent a mosaic of soils, similar to some of the soils formed by podzolization in the podzol soils (= spodosol) region in the northern part of the lower peninsula and in the gray-brown podzolic soil (= alfisol) region of the southern part of the lower peninsula. The northern boundary of the alfisol region generally coincides with the southern limits of white pine (Pinus strobus) communities (Braun 1974; Hutchison 1979; Miller 1964; Veatch 1953; Whiteside et. al. 1963, 1964).

Vegetation also has an essential role in the development of soils, and, conversely, soils have an effect on the development of vegetation. These concepts are considered when selected aspects of Michigan's vegetation are discussed in the next section. The focus is on the transition zone, especially for the study areas in Midland County.

\subsection{Vegetation}

No specific studies on the original vegetation of Midland County, Michigan, were located. Darlington's (1945) thorough review of floristic work done as early as 1827 in Michigan (accompanicd by a comprehensive bibliography) does not mention Midland County, although it does list several other counties in reference to various botanical studies. The history of Michigan's forests as affected by anthropogenic developments is discussed by Davis (1964), McIntire and McKee (1964), and Smith (1964). Several recent botanical workers synthesized qualitative and quantitative information and made interpretations that led to a generalized compositional and structural classification of Michigan's forest and nonforest communities, both regionally and locally (Braun 1974; Darlington 1945; Elliott 1953; Maycock and Curtis 1960; Voss 1972).

The native forest vegetation of the lower peninsula of Michigan has two major climatic climax regions. The hemlock-white pine-northern hardwood forest region (formation) in the northern portion coincides with the podzol soil (spodosol) region; the beech-maple forest region (formation) in the southern portion coincides with the gray-brown podzolic soil (alfisol) region 
(Fig. 6). In addition, there is a vegetational transition zone extending across the middle of the lower peninsula, where the floristic elements from both forest regions integrate (Fig. 6).

The hemlock-white pine-northern hardivood forest region is characterized by a mosaic of deciduous hardwood forests, coniferous fortsts, and mixed hardwood-coniferous forests. The climax forest dominants include Acer saccharum (sugar maple), Fagus grandifolia (American beech), Tilia americana (basswood), Betula lutea (yellow birch), Tsuga canadensis, (eastern hemlock), Ulmus americana (American elm), Acer rubum (red maple), Fraxinus americana (white ash), Quercus rubra var. borealis (northern red oak), Fraxinus nigra (black ash), and Pinus strobus (eastern white pine). However, these taxa do not occur in all parts of the region (Fig. 9). Furthermore, Picea glauca (white spruce) and Abies balsamea (balsam fir) are considered important components in the northern limits of this region (Braun 1974; Maycock and Curtis 1960).

In the beech-maple forest region, Fagus grandifolia and Acer saccharum are the dominant trees. Associated arborescent taxa include Ulmus americana, Tilia americana, Liriodendron tulipifera (tulip tree), Quercus borealis var. maxima (red oak), Carya ovata (shagbark hickory), Platanus occidentalis (sycamore), Celtis occidentalis (northern hackberry), Fraxinus americana, Prunus serotina (black cherry), and Juglans nigra (black walnut). As do other vegetational formations, the beech-maple forest region consists of a mosaic of plant communities, where deviations from normal topography and soils support different climax communities (Braun 1974).

Floristic features of the transition zone across the middle portion of the lower peninsula apparently have received little attention from a plant ecological perspective. Braun (1974) mentions that going northward from the beech-maple forest region, the occurrence of hemlock and white pine is accompanied by an increasing number of northern herbaceous and shrub species indicative of the transition to the hemlock-white pine-hardwood forest region. When beech-maple communities occur north of the transition zone, their understory components are species of northern affinity such as Acer pensylvanicum (striped maple), Acer spicatum (mountain maple), Viburnum lentago (nannyberry), Rubus idaeus var. strigosus (wild red raspberry), Lonicera canadensis (American fly honeysuckle), Sambucus pubens (red-berried elder), Aralia nudicaulis (wild sarsaparilla), Dryopteris spinulosa (shield fern), Maianthemum canadense (wild lily-of-thevalley), and Clintonia borealis (corn lily) (Braun 1974). Voss $(1972,1985)$ has found that some plant species rarely occur south of the transition zone, whereas other species of southern origin rarely occur north of this zone. In the genus Carex (sedge), for example, Carex aenea is well represented in the northern portion of the lower peninsula (and across the upper peninsula) but has not been found south of Midland County. In contrast, Carex muskingumensis is rather widespread in the southern portion of the lower peninsula but has not been discovered north of Midland County. A list of additional plants with one of these two distribution patterns compiled from the taxon distribution maps published in Voss $(1972,1985)$ is provided in App. B. Taxa of this study will be compared with the taxa listed in App. B to ascertain whether changes in the diversity of forest communities (excluding taxa from seeding the ROW) caused by the ROW are related to plants of northern or southern affinities. 


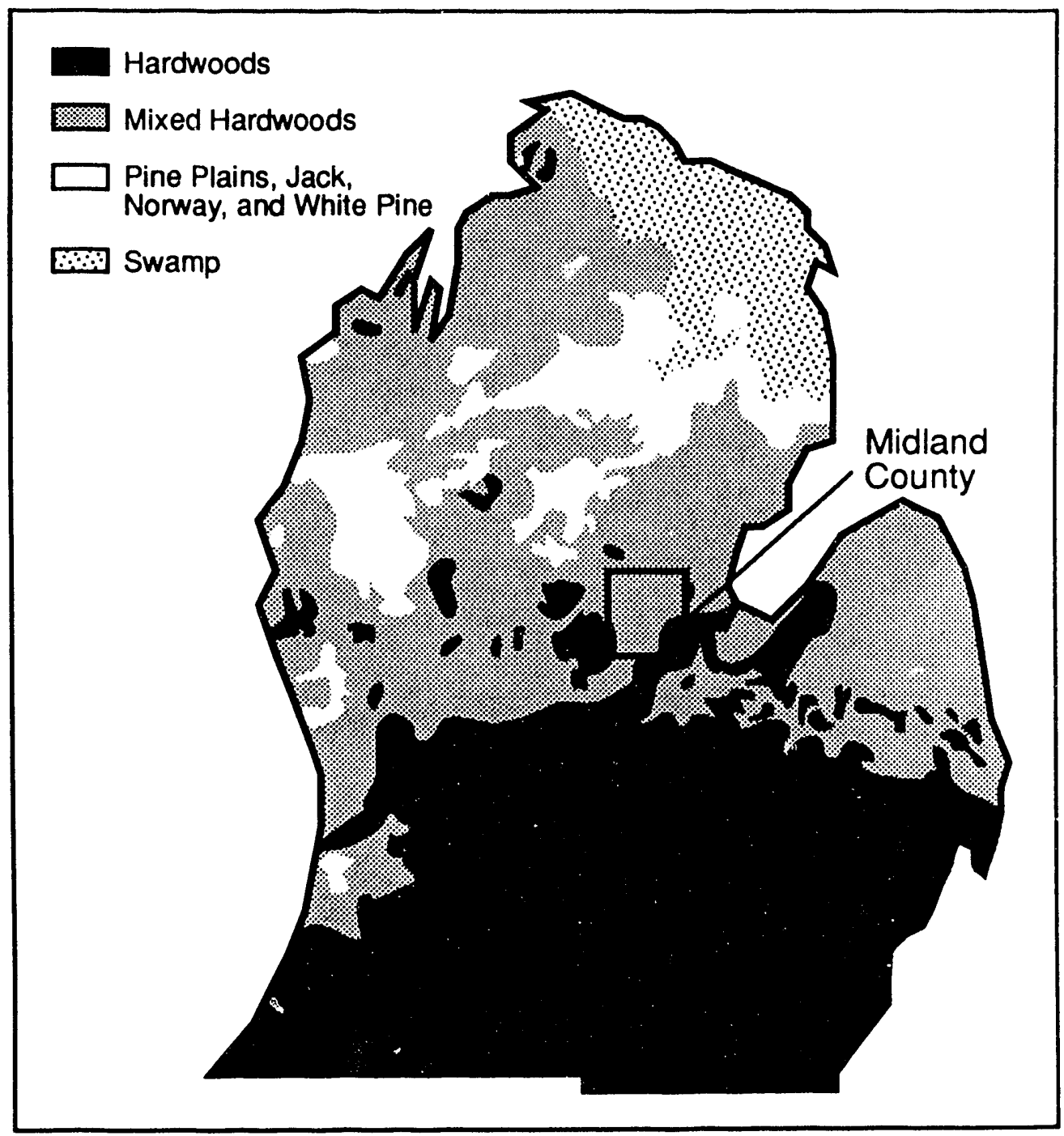

FIGURE 9 Vegetation Map Depicting the Original Forests of Michigan's Lower Peninsula (Adapted from McIntire and McKee 1964)

The way in which the floristic elements from the northern and southern portions of the lower peninsula are expressed in the heart of the transition zone (Midland County) has not been the focus of any known botanical studies. The closest detailed study within recent years seems to be Elliott's (1953) impressive study of Missaukee County (Fig. 6), located along the northern margin of the transition zone. He used density and basal areas to analyze the trees and shrubs on stands of upland second-growth hardwood forest in six different soil series of the podzol group. Elliott concluded that the county's second-growth hardwood stands, as a group, represented an anthropogenic disclimax. Also, the dominant trees of this disclimax represented members of the northern hardwood forest, namely Acer saccharum, Fagus grandifolia, Tilia americana, Fraxinus americana, Betula lutea, Tsuga canadensis, Ulmus americana, and Ulmus thomasi (cork elm). Mixed among these taxa, but of less importance, were Betula papyrifera (white birch), Quercus rubra var. borealis, Acer rubrum, Populus grandidentata, (bigtooth aspen), Populus tremuloides (quaking aspen), and Prunus pensylvanica (pin cherry). The boreal trees and shrubs reported by 
Elliott (App. C) will be compared with those at the sites. It is important to determine whether climatic modifications within the edge of the forest favor elements of northern or southern origin and thus influence the direction of vegetational shifts. 


\section{Pipeline Construction}

Activities involved with pipeline construction included surveying the ROW; clearing the woody vegetation from the ROW; excavating a ditch approximately $2 \mathrm{~m}(6.6 \mathrm{ft})$ deep and $1 \mathrm{~m}$ $(3.3 \mathrm{ft})$ wide; distributing, weldin, and installing the pipe; backfilling the ditch; and final grading and seeding the ROW with a mixture of grasses and legumes. Pipeline construction at the two study sites took place during the spring and early summer of 1989 (Fig. 10). The final survey for the pipeline was done during early April 1989. By this time, some of the larger trees had already been removed from the ROW at Site 1 (between October 17, 1988, and March 6, 1989), but no trees had been removed from the ROW at Site 2. The remainder of the trees were cleared from the ROW at both sites during late April and early May 1989 . Slash was used to construct a crude roadbed in wet areas on the working side of the pipeline (the southern portion of the ROW). All logs had been removed from the ROW at Site 1, but the logs from the clearing operation at Site 2 were piled in a row along the northern edge of the ROW. In several places, logs had rolled into the adjacent forest on the north side of the ROW.

Pipeline installation at the sites occurred between May 18 and 25, 1989. At that time, standing water covered approximately $50 \%$ of the soil surface of the ROW at each site. Because of the wet soil conditions, trenching was carried out with a backhoe, working from the crude slash road. Excavated soil was piled on the northern portion of the ROW, and some soil spilled into the adjacent forest at both sites. In some places at Site 2, the excavated soil nearly covered the logs piled along the northern edge of the ROW. The welded and coated pipe was placed in the pipe ditch soon after ditching was complete, and the trench was backfilled with sufficient soil to anchor the pipe. Final grading of the ROW was carried out in mid-June 1989 and involved burying stumps and other debris, which were excavated during the trenching operation, in the ROW and final leveling of the pipe ditch. Stumps that did not interfere with the trenching operation were allowed to remain rooted. The slash road was abandoned at both sites, and the logs were also left along the northern edge of the ROW at Site 2. It appears that during the trenching and backfilling operations through both sites, there was no effective procedure for separately removing and replacing topsoils and subsoils. During backfilling and final grading, some of the logs along the northern edge of the ROW at Site 2 were pushed up to $5 \mathrm{~m}(16.4 \mathrm{ft})$ into the adjacent forest to recover the soil that had spilled over the row of logs during trenching. Also at Site 2, an intermittent furrow paralleling the pipeline on the storage side of the ROW was excavated during the backfilling and final grading. Apparently the soil from the furrow area was used to help fill the pipeline ditch.

The ROW at both sites was hand seeded on June 14, 1989. Specifications called for the use of two seed mixtures. One mixture designated for use on organic soils consisted of:

Lotus corniculata, birds-foot trefoil, at $4.5 \mathrm{~kg} / \mathrm{ha}$ (4 lb/acre);

Phleum pratense, Timothy, at $5.6 \mathrm{~kg} / \mathrm{ha}$ (5 lb/acre);

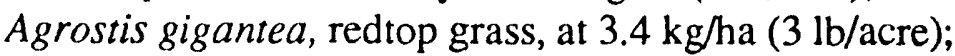

Trifolium hybridum, alsike clover, at $2.2 \mathrm{~kg} / \mathrm{ha}$ ( $2 \mathrm{lb} / \mathrm{acre})$; and

Trifolium repens, white Dutch clover, at $3.4 \mathrm{~kg} / \mathrm{ha}$ ( $3 \mathrm{lb} / \mathrm{acre})$. 


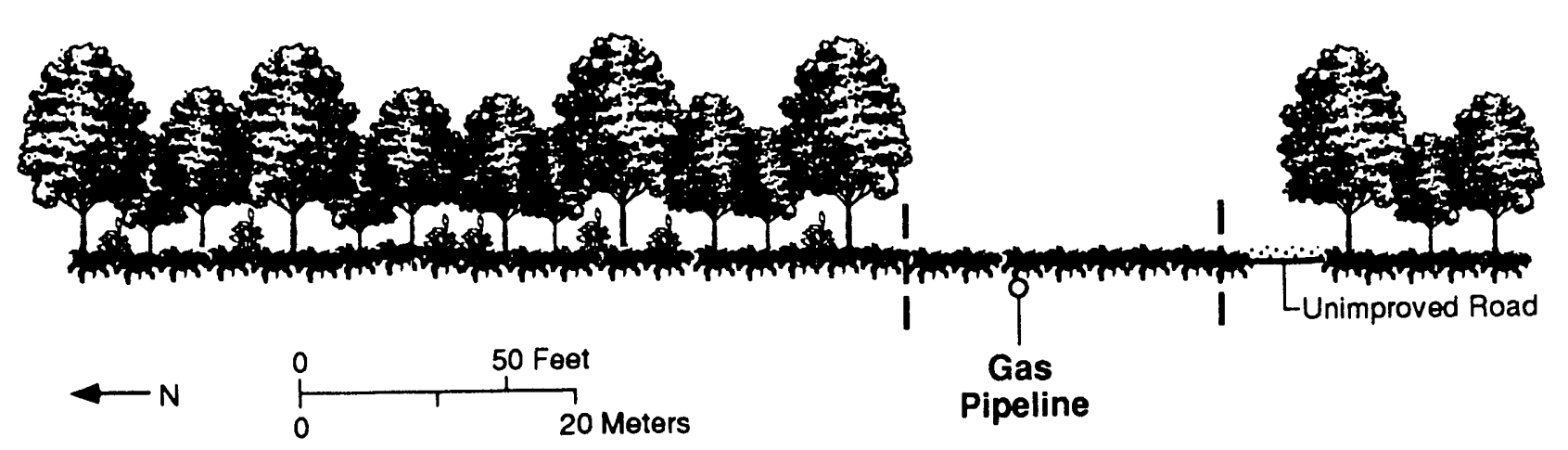

FIGURE 10 Sectional Drawing Typifying the Physiognomy of Sites 1 and 2: Adjacent Forest, Right-ofWay, and Unimproved Gordonville Road

The second mixture designated for use on mineral soils consisted of:

Festuca rubra, red fescue, at $33.6 \mathrm{~kg} / \mathrm{ha}$ (30 lb/acre);

Festuca arundinacea, tall fescue, at $11.2 \mathrm{~kg} / \mathrm{ha}$ (10 lb/acre);

Lolium perenne, perennial ryegrass, at $5.6 \mathrm{~kg} / \mathrm{ha}(5 \mathrm{lb} / \mathrm{acre})$;

Bromus inermis, smooth bromegrass, at $5.6 \mathrm{~kg} / \mathrm{ha}$ ( $5 \mathrm{lb} / \mathrm{acre})$;

Agrostis gigantea, redtop grass, at $1.1 \mathrm{~kg} / \mathrm{ha}$ (1 lb/acre); and

Trifolium repens, white Dutch clover, at $1.1 \mathrm{~kg} / \mathrm{ha}(1 \mathrm{lb} / \mathrm{acre})$.

In addition, $224 \mathrm{~kg} / \mathrm{ha}$ (200 lb/acre) of 12-12-12 fertilizer, equivalent to $26.9 \mathrm{~kg} / \mathrm{ha}$ (24 lb/acre) of $\mathrm{N}, \mathrm{P}_{2} \mathrm{O}_{5}$, and $\mathrm{K}_{2} \mathrm{O}$ each, was to be applied to seeded sections of the ROW. It would seem that the seed mixture for organic soils should have been used on both sites; however, a verification of which one of the seed mixtures was actually applied could not be made.

During the site visit in mid-August 1989, the surface of the ROW at Site 1 had considerably more exposed soil and less standing water than did the surface of the ROW at Site 2. The ROW at Site 2 had several large depressions on the north side of the pipe ditch, indicating that the cleanup crew must have had difficulty gathering enough soil to fill the pipe ditch and had resorted to borrowing soil from the north side of the ROW to fill it. This lack of soil had occurred partially because the excavated soil had spilled over and into the logs piled on the northern edge on the ROW at Site 2. The abandoned logs at Site 2 remained relatively undisturbed until October 1989 , when portions were removed by individuals with permits to cut firewood in state forest lands.

There has been no evidence of additional work related to the GPL installation activities on the ROW at either site since early July 1989 . Incidental traffic by off-road vehicles and the pick-up trucks used by firewood cutters in October 1989 has created deep ruts in some of the wetter areas. Most of the logs still remain on the ROW and in the adjacent forest at Site 2. 


\section{Methods}

This study is comparative with respect to both structural and floristic aspects of plant communities; thus, it is directed toward the descriptions and analyses of major vegetational synusiae (layers) and designated trees, shrubs, brambles, vines, forbs, graminoids, pteridophytes, and bryophytes. (Graminoids include grasses, sedges, and rushes; pteridophytes include ferns and fern allies such club mosses and horsetails; and bryophytes include mosses, liverworts, and hornworts.) Also, to determine methods of making ecological measurements, the vegetation has been divided into three gross structural components: the overstories of adjacent forest communities, the understories of adjacent forest communities, and the ROW plant communities. The overstory component consists of trees and shrubs with stems $\geq 2 \mathrm{~cm}(\geq 0.78 \mathrm{in}$.) in diameter at breast height ( $\mathrm{dbh}$, the stem diameter at $1.5 \mathrm{~m}$ [58.6 in.] above the ground surface). The understory component consists of seedlings of trees and shrubs with a stem $\mathrm{dbh}<2 \mathrm{~cm}$, brambles, vines, forbs, graminoids, pteridophytes, and bryophytes. Sampling is being carried out on the ROW and in the adjacent forest north of the ROW, because there is no forest remaining between the southern boundary of the ROW and the unimproved Gordonville Road (Fig. 10). The use of the forest south of the unimproved Gordonville Road for the study is unacceptable because of the road and its edge effects. In addition, edge effects of the ROW on the adjacent forest are likely to be more pronounced along the northern boundary of the ROW, because of greater insolation at the understory level, than along the southern boundary of the ROW.

\subsection{Sampling Procedures}

Because the northern edge of the ROW was not clearly marked after pipeline construction, it was located at each site by measuring $22.86 \mathrm{~m}$ ( $75 \mathrm{ft})$ norti from the lath stakes put down by the pipeline surveyors to mark the southern ROW boundary. At at each site, a random point along the northern edge of the ROW was selected as a western boundary for the understory vegetational study area. From this point, a distance of $104 \mathrm{~m}(341.2 \mathrm{ft})$ was measured eastward, along the northern edge of the ROW, to establish the eastern boundary of the study area. Subsequently, these western and eastern boundary points were used as starting points to establish the south-north boundary lines for the sampling transects. Along these south-north lines, transect markers $(1 / 2 \times 24$-in. steel reinforcing rods) were placed $1,5,13,25,41$, and $61 \mathrm{~m}$ into the forest from the northern edge of the ROW (Fig. 11). Also, rod transect markers were placed at the same intervals midway between the western and eastern boundaries for orientation purposes. East and west transect markers were placed $104 \mathrm{~m}$ apart, to allow $2 \mathrm{~m}$ on each end of each $100-\mathrm{m}$ (328-ft) transect, so the area within or next to the quadrats to be sampled along the transects would not be trampled on. All transect marker rods are identified with metal tags. In addition, more permanent steel markers (automobile axles) were driven into the ground to near the soil surface, $1 \mathrm{~m}$ in from the west transect marker rods, $1 \mathrm{~m}$ in from the east transect marker rods, and 13 and $61 \mathrm{~m}$ north from the northern edge of the ROW.

The actual establishment of a transect line for each data-collection area is being accomplished by attaching the zero end of a 100-m survey tape to a $2-\mathrm{m}$ chain that is attached to the 


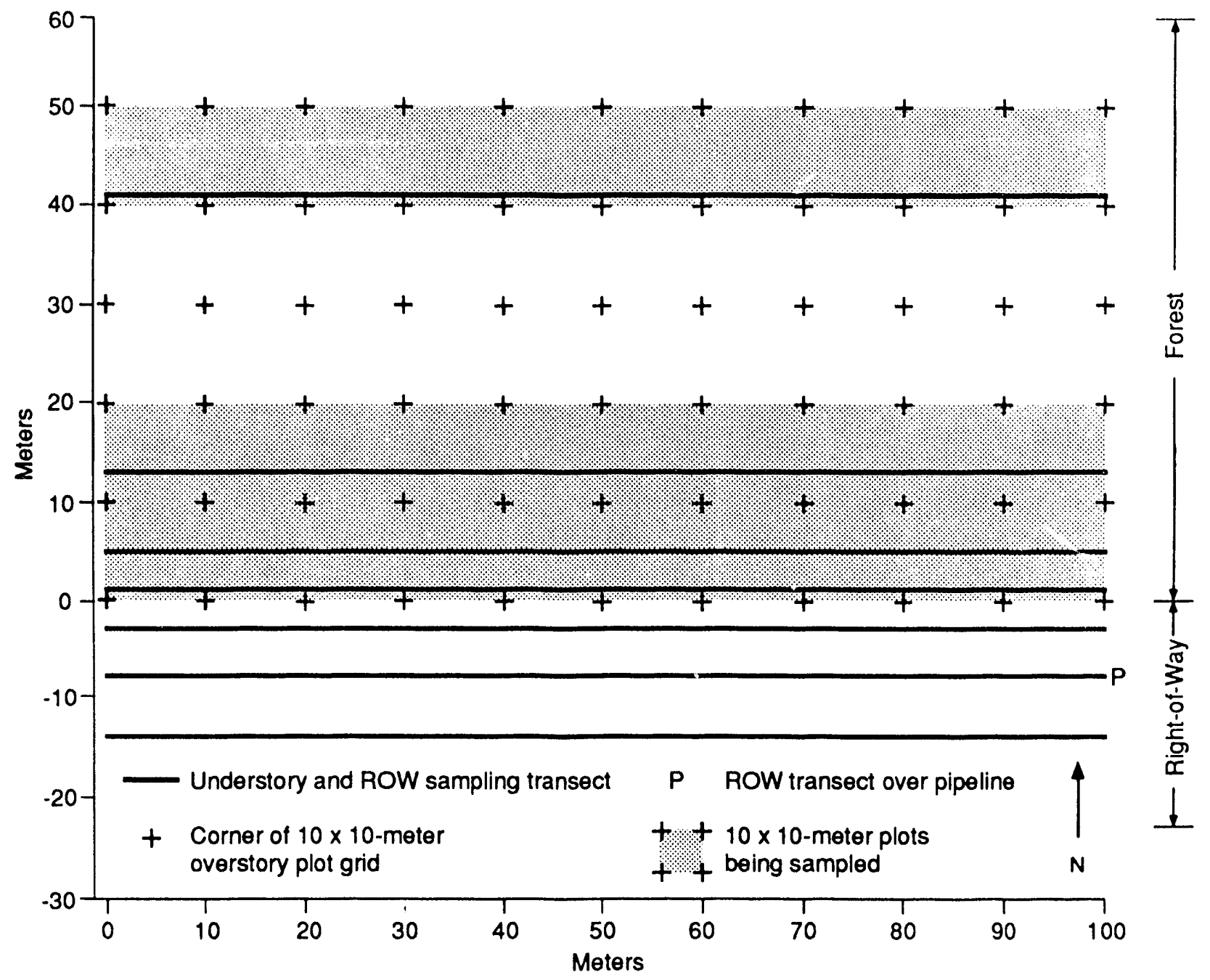

FIGURE 11 Positions of Understory Transects, Right-of-Way Transects, and Overstory Plots for Both Sites

western marker rod. The tape is stretched to the eastern end of the transect and attached to a second 2-m chain that is attached to the eastern marker rod. The chain length is then adjusted to make the survey tape taught. To visually facilitate the placing of the tape through the forest and to avoid trampling on the sampling side (south) of the transect lines, yellow lath stakes were installed at 10-m intervals along the transect lines in the forested portions of each site. Because lath stakes are thin and weak, short oak stakes were implaced at 20 -m intervals as backup markers along the same transect lines.

Transect markers in the forest were used as references to establish the east and west ends of the ROW sampling transects. Three parallel transect lines, placed 3, 7.6 (over the GPL), and $14 \mathrm{~m}$ south of the northern edge of the ROW, were established at each site. Neither steel nor lath markers were installed on the ROW because maintenance vehicles were expected to travel there. However, coded oak stakes were placed at the ends and at 20-m intervals along each ROW transect 
line to facilitate the reestablishment of the $100-\mathrm{m}$ transect during data collection. For sampling, a survey tape is placed on the transect line in a matter similar to that described for the forest transects, except that the steel rods used to attach the chain extensions are being removed after each datacollection effort.

To sample the understory, cover-class values and individual counts of selected taxa are being recorded on prepared data sheets for four transects in the forested portions and three transects in the ROW at each site (App. D). A $1 \times 1-\mathrm{m}$ quadrat frame is placed along the southern edge of the 100-m survey tape randomly, either immediately east or west of the odd-numbered meter marks on the tape. One quadrat is sampled at all odd-numbered meter marks from 5 to 43 and 55 to 93 , resulting in a total of 40 quadrats per transect. The ends and the centers of the transects are not used so that no sampling is done in areas that would get trampled.

In the forested portion at each site, the transect lines used for sampling are located $1,5,13$, and $41 \mathrm{~m}$ north of the north edge of the ROW. To help keep the data organized, numbers were assigned to these transects: 101, 105, 113, and 141 for Site 1 and 201, 205, 213, and 241 for Site 2. In the ROW at each site, the transect lines used for sampling are located 3, 7.6 (over the GPL), and $14 \mathrm{~m}$ south of the northern edge of the ROW. (A transect located $5 \mathrm{~m}$ south was sampled in 1989, but it is no longer being used for vascular plant sampling.) Numbers assigned to these transects are 503, 507.6, and 514 for Site 1 and 603, 607.6, and 614 for Site 2.

To establish plots for overstory sampling, a grid of $10 \times 10-\mathrm{m}$ plots that is $100 \mathrm{~m}$ wide (west-east and parallel with the ROW) and $50 \mathrm{~m}$ deep (south-north) was superimposed on the understory-forest transects at each site. Red lath stakes mark the location coordinates of the grid. The starting location for the grid at each site was $2 \mathrm{~m}$ east of the western boundary of the forestunderstory transects along the northern edge of the ROW. From this starting point, at each site, laths were placed in a row from west to east at $10-\mathrm{m}$ intervals along a $100-\mathrm{m}$ line. The grid at each site was completed by establishing five more rows of laths located 10,20,30,40, and $50 \mathrm{~m}$ north of the northern edge of the ROW (Fig. 11).

To sample the overstory, stem diameters are measured for all individuals of each overstory species (trees and shrubs with stems $\geq 2 \mathrm{~cm} \mathrm{dbh}$ ) in three $10 \times 100-\mathrm{m}$ belt transects with the long axis of the transect parallel to the ROW. Each belt transect is made up of ten $10 \times 10-\mathrm{m}$ plots. The three transects cover the areas extending from 0 to 10,10 to 20 , and 40 to $50 \mathrm{~m}$ north of the northern edge of the ROW (Fig. 11). Prepared data sheets (App. E) are used to record the dbh (in centimeters) as measured with a diameter tape. In addition, the location of each individual overstory species is mapped in each $10 \times 10-\mathrm{m}$ plot. The mapping is done on prepared sheets, on which each $10 \times 10-\mathrm{m}$ plot is subdivided into $1 \times 1-\mathrm{m}$ units (App. F) and each overstory plot is assigned a number that reflects the site and location (App. $G$ ).

Systematic sampling of the bryophyte synusiae to ascertain cover estimates for individual species is being carried out by collecting core specimens along transect lines. A 100-m tape is used to establish two transect lines, one $10 \mathrm{~m}$ north and the other $40 \mathrm{~m}$ north of the northern edge of the ROW, for sampling in the forested portion at each site. On the ROW, at each site, the transect lines are $5 \mathrm{~m}$ south of the northern edge of the ROW. Sampling is done at $0.5-\mathrm{m}$ intervals along the transect lines with a 5.8-cm-diameter coring device. Sample cores are taken near the southern 
edge of the transect line in the forested portions at each site and near the northern edge of the transect line on the ROW at each site. Only sample cores that contain shoots of mosses or liverworts are kept in labelled brown paper bags for laboratory analyses.

\subsection{Plant Inventories}

According to Daubenmire (1968, pg. 39):

At the beginning of any serious study of a plant community it is important not only to learn precisely which species are present, but to be able to recognize them at different stages of development. The time is not long past when the field biologist felt well satisfied with his work after presenting a mere list of the dominants, identifying these as they came into flower. It is now widely acknowledged as poor policy to learn only a few dominants and neglect the remaining flora. Subordinate and even rare plants often have much value for indicating special conditions, present and past, and they sometimes foretell the future. All species have some indicator significance, whether it is known at present or not.

The documentation of species with voucher specimens is also critical, because any changes in the floristic elements, especially the loss of a species, can be confirmed with credibility only if a voucher specimen has been preserved.

In this study, voucher specimens of vascular plants are collected for each species except for those considered rare or known to be endangered. Specimens freshly collected in the field are referenced by collection number and field notes and placed in plant presses for drying. When dry, specimens are mounted on standard-size herbarium sheets (Porter 1967). When provided with an information label, each mounted specimen provides permanent documentation of a given species. Rare and endangered plant species are photographed in situ (in their habitats), and prints (19.5 $\mathrm{x}$ $16 \mathrm{~cm}$ or $8 \times 16 \mathrm{in}$.) of the photographs are mounted on standard-size herbarium sheets with appropriate labels to be used as herbarium specimens to provide permanent documentation.

Voucher specimens of bryophytes are also being prepared. Field-collected specimens are placed in small, numbered, brown paper bags, and field notes are recorded. The specimens are dried in the bags and stored for laboratory work. Specimens too large or too wet to be dried in collection bags are removed from the bags and dried separately. Collected bryophytes are usually air dried at room temperature, but sometimes oven drying (at about $70^{\circ} \mathrm{C}$ or $180^{\circ} \mathrm{F}$ ) is needed for large collections. Finally, the bryophyte voucher specimens are placed in bond paper packets (ca. $10 \times 15 \mathrm{~cm}$ or $4 \times 6$ in.) with appropriate labels. Because bryophytes are small, the use of packets is usually the herbarium technique chosen for handling specimens (Conard 1979). These herbarium specimens provide permanent documentation of the mosses and liverworts collected from the sites.

Many taxonomic reference sources are being used to key the vascular plant voucher specimens, to confirm field identifications or identify unknown species. Particularly important for 
this study are these manuals on Michigan's flora: Barnes and Wagner (1981) for trees, Billington (1949) for shrubs, Smith (1966) for wildflowers, Voss (1972) for gymnosperms and monocots, and Voss (1985) for dicots in part (Saururaceae-Cornaceae). Additional helpful manuals include but are not limited to these: Cores and Ammous (1958), Fernald (1950), Gleason (1952a,b,c), Graves (1956), Hithchcock (1950a,b), and Swink and Wilhelm (1979).

For the vascular plant species in the study collection, the scientific names follow those used by Voss $(1972,1985)$ when they are included in the families covered in the two volumes presently in print on Michigan's flora. For the species in the remaining dicot families and the pteridophytes, the scientific names follow those used by Gleason, volume one (1952a) and volume three (1952c). During the identification process, critical information for each specimen of vascular plant is recorded on taxon data sheets (App. H); similar taxon data sheets are also used for the bryophyte species. Major taxonomic references for Michigan's bryoflora are Crum (1983) and Darlington (1964) for mosses and Steere (1940) for liverworts. In addition, other useful manuals include but are not limited to Conard (1979), Schuster (1966, 1969, 1974, 1980), and Welch (1957). Scientific names for the species of bryophytes in the study collection follow those used by Crum and Anderson (1981a,b) for the mosses and Conard (1979) for liverworts.

\subsection{Qualitative Procedures}

As identifications of the vascular plant voucher specimens are confirmed, a master list of species, by scientific name, is being compiled. This list includes family and common names as well as collection numbers. Separate plant lists for the forest and ROW plant communities at the sites are being periodically compiled. Such lists are needed for determining possible additions to or losses from the site plant communities. The final list will be compared with the list of known vascular flora reported for Midland County (App. I), and information on new species will be added to county records.

Taxon lists for the bryophytes will be prepared in the same format as that used for the vascular plants, except common names will not appear in the master list, since they are essentially unknown for mosses and liverworts.

Taxon lists of the vascular plants with reference to different growth forms are also being prepared from time to time for trees, shrubs, brambles, vines, forbs, graminoids, and pteridophytes. Such lists can provide information about possible structural changes in forest and ROW plant communities at the sites.

\subsection{Quantitative Procedures}

The quantitative procedures used to measure vegetational components are determined by the particular units of measure that were chosen for analysis in this study. The histories, applications, merits, and limitations of these different units of measure (such as density, cover, biomass, etc.) have been thoroughly reviewed in the ecologic literature. Noteworthy references include Bonham (1989), Daubenmire (1968), Greig-Smith (1964), and Mueller-Dombois and Ellenberg (1974). 
This study employs density, cover, basal area, and frequency, all of which can be measured by nondestructive sampling techniques.

Density refers to the number of individuals per unit area (or volume). It is being determined for the woody taxa of the overstories of the forest communities and the understories of the forest and ROW plant communities. For the overstories, counts of trees and shrubs with stems of $\geq 2 \mathrm{~cm}$ ( $>0.79 \mathrm{in}$.) dbh are being made in $10 \times 10-\mathrm{m}$ plots. Dead stems are not included for density determinations, but the death of any trees and shrubs during the study will be noted. Counts are being made in $1 \times 1-\mathrm{m}$ plots for vines, shoots of brambles, and understory trees and shrubs with stems of $<2 \mathrm{~cm} \mathrm{dbh}$.

Cover for a piant species is a measure of dominance and is expressed as the percentage of the ground surface covered by the vertical projection of the total foliar spread of all individuals of a species in a specified area. The concept of cover can also include inanimate environmental components, such as rocks, logs, and water. In this study, cover estimates are being made by recording cover-class values (Apps. $\mathrm{J}$ and $\mathrm{K}$ ) for the understory taxi of the forest and ROW plant communities in $1 \times 1-\mathrm{m}$ plots. Cover estimates are also being made for bryophytes, pteridophytes, graminoids, and forbs. Cover estimates are being made for individual species of ferns, fern allies, grasses, sedges, rushes, vines, brambles, and seedlings of trees and shrubs (with stems $<2 \mathrm{~cm}$ $\mathrm{dbh}$ ). When applicable, cover estimates are also being made for exposed mineral soil, bare logs, stumps, and standing water. Cover estimates for individual species of mosses and liverworts are being made from field-collected sample cores $(5.8 \mathrm{~cm}$ or ca. $3 \mathrm{in}$.). Because bryophytes are small and because microscopy is needed to identify species of mosses and liverworts, the sample cores are being analyzed in the laboratory.

Basal area is an assessment of dominance and refers to the aggregate cross-sectional area at or near ground level of individual plants in a specified area. The basal areas of the trees and shrubs are determined for the overstories of the sites. Stems $\geq 2 \mathrm{~cm} \mathrm{dbh}$ are being measured within $10 \times 10-\mathrm{m}$ plots. The diameters are then converted to circular areas, and the circular areas are summed for each species.

Frequency provides information about the distribution of a taxon, without regard to its density or dominance, and is expressed as a percentage of occurrence of a taxon in a series of plots of the same size. In this study, for the understory species (except bryophytes), frequency is being calculated from the same data recorded to determine percent cover. For the overstory species, frequency is being calculated from the same data recorded to determine basal areas. Frequencies of understory and overstory taxa cannot be combined or meaningfully compared in this study, even for the same species, because different quadrat and plot sizes are being used $(1 \times 1 \mathrm{~m}$ and $10 \times 10 \mathrm{~m}$ ). For the mosses and liverworts, frequency is being ascertained from core specimens. 


\section{Field Trip Summaries}

This summary of field trips from August 1988 through August 1990 is taken from a series of more comprehensive reports prepared shortly after each field trip for internal records. During all the field trips except the first one in August 1988, at least some plant specimens were collected for taxonomic work and to build a collection of voucher specimens. Still photographs were also taken during each trip. Because these two activities are routine for this project, they are not mentioned in these brief summaries.

\subsection{August 3-4, 1988}

Investigators: S.D. Zellmer and J.R. Rastorfer, in collaboration with Dr. John Rochow, Supervisor, Environmental Department, Consumers Power Company, and Mr. Thomas Morvant, ROW agent representing Consumers Power Company.

Activities: Three potential study sites were reconnoitered. One was considered to be most suitable for the study; it can be classified as a deciduous forested wetland. This site is located a short distance west of the junction of Castor and Gordonville Roads and is now designated Site 2 on $\mathrm{Mj}^{\mathrm{j}}$ 'nigan state forest land.

\subsection{October 13-17, 1988}

Investigators: S.D. Zellmer, J.R. Rastorfer, J.D. Taylor, and G.D. Van Dyke.

Activities: The location of Site 1 within the boundary of Mr. Billy Haskins' property was established. To make an ecologic evaluation of this site, the densities and basal areas of species of trees and shrubs in six different plots $(4 \times 25 \mathrm{~m})$ were determined and recorded. Several increment bores were taken from selected trees to determine age. Soil cores were inspected to confirm soil map information, and soil samples were collected for laboratory analyses.

\subsection{March 6-10, 1989}

Investigators: J.R. Rastorfer and G.D. Van Dyke.

Activities: Reference materials on endangered plant species, wetlands, and other natural features were obtained from the Michigan Department of Natural Resources (MI DNR) in Lansing, on the way to Midland County. A review of the research plans, especially for the second site on Michigan state forest land (Site 2), was discussed with a state forester, Mr. Michael Conley, at his office in Gladwin, Michigan. The Department of Biological Sciences and the main library at Central Michigan University in Mt. Pleasant was visited to assess the university's herbarium and 
botanical/ecological literature resources. Data were recorded to determine densities and basal areas of trees and shrubs in six plots $(4 \times 25 \mathrm{~m})$ to make an ecologic evaluation of Site 2.

\subsection{April 11-16, 1989}

Investigators: J.R. Rastorfer and G.D. Van Dyke.

Activities: Site 1 and Site 2 were inspected, and video-tape recordings were made of the forest characteristics at each site to provide visual documentation of the sites before vegetation is cleared from the ROW. The locations of surveyor stakes that delineate the ROW through each site were noted and recorded. Data were collected to determine densities and basal areas of species of trees and shrubs in two $10 \times 150-\mathrm{m}$ belt transects at Site 2 for evaluation and to test sampling adequacy. Cover-class values were recorded collectively for the bryophyte synusia along two $150-\mathrm{m}$ transects using a $20 \times 50-\mathrm{cm}$ frame.

\subsection{May 10-12, 1989}

Investigators: G.D. Van Dyke and S.D. Zellmer.

Activities: Different phases of the gas pipeline construction operations were observed, discussed, and recorded on video tape. Information was obtained from Mr. Richard Lybarger, the field construction superintendent for Consumers Power Company, on pipeline construction procedures and the two seed mixtures to be sown on the nonagricultural ROW. The major objective of this trip was to observe and document the construction of a study site to compare the effects of single- and double-ditching on agricultural crop production. This second objective is the subject of another ongoing research effort sponsored by GRI and located nearby on the same pipeline ROW.

\subsection{May 22-26, 1989}

Investigators: J.R. Rastorfer, G.D. Van Dyke, and J.E. Frelichowski.

Activities: Additional video-tape recordings were made of different phases of the gas pipeline installation operations. The northern boundary of the ROW was located at each site using the surveyor stakes along the southern boundary of the ROW. Markers were placed in the forested portion of each site for four transects at points $1,5,13$, and $41 \mathrm{~m}$ north of the northern edge of the ROW. 


\subsection{June 5-13, 1989}

Investigators: J.R. Rastorfer, G.D. Van Dyke, J.E. Frelichowski, and M.G. Slocum.

Activities: Cover-class values were recorded for understory taxa along three transects in the forested portion of each site. The transect located $1 \mathrm{~m}$ north of the northern edge of the ROW could not be analyzed because the grading work on the ROW was not completed. Seedling counts of trees and shrubs and shoots of brambles and vines were also recorded. Data from forty $1 \times 1-\mathrm{m}$ quadrats were collected along each transect; hence, a total of 240 quadrats were sampled. The $10 \times 10-\mathrm{m}$ grid network of lath, used to analyze the overstory components (trees and shrubs), was installed in the forested portion of each site. Cover-class values for standing surface water were recorded in the forested portion of each site to provide comparative information for the two sites. These cover estimates were done using the $1 \times 1-\mathrm{m}$ quadrat along a transect located $30 \mathrm{~m}$ north of the northern edge of the ROW.

\subsection{June 5-8, 1989}

Investigator: G.D. Van Dyke.

Activities: Plant specimens were collected from Sites 1 and 2 and from the surrounding area for taxonomic work in preparation for ecologic sampling in August 1989.

\subsection{July 17-21, 1989}

Investigators: J.R. Rastorfer and J.E. Frelichowski.

Activities: The bryophyte synusia was systematically sampled along two transects in the forested portions of each site. A total of 192 bryophyte samples were collected from 804 sample points. Selected vascular plants were collected from both sites and from the surrounding area for additional taxonomic work in preparation for the ecologic sampling in August 1989.

\subsection{August 7-16, 1989}

Investigators: J.R. Rastorfer, G.D. Van Dyke, and M. Slocum.

Activities: Cover-class values were recorded for the understory species along four transects in the forested portion and one transect in the ROW segment of each site. In addition to cover-class values, counts were also recorded for seedlings of trees and shrubs and shoots of brambles and vines. Forty $1 \times 1-\mathrm{m}$ quadrats were sampled along each transect, resulting in understory taxa data for a total of 480 quadrats. Trees and shrubs with stems $\geq 2 \mathrm{~cm}$ dbh were 
recorded by species on the ten $10 \times 10$-m plots from the three belt transects at each site, resulting in overstory taxa data for a total of 60 plots.

\subsection{October 12-15, 1989}

Investigators: J.R. Rastorfer and G.D. Van Dyke.

Activities: Several vascular plant specimens, critical because of their late maturity, were collected. Lath markers were placed at selected locations in the forested portion and on the ROW at each site for additional soil sample collections. Voucher specimens were collected for mosses seen for the first time on the ROW after pipeline construction activities.

\subsection{June 4-8, 1990}

Investigators: G.D. Van Dyke and J.E. Frelichowski.

Activities: Plant specimens were collected in preparation for ecological sampling in August 1990. Cover-class values were recorded for standing surface water in the forested portion of each site.

\subsection{July $2-6,1990$}

Investigators: J.R. Rastorfer and J.E. Frelichowski.

Activities: Three new transects were established on each ROW at each site. A special collection of plant specimens was made on the ROW in preparation for ecological sampling in August 1990.

\subsection{July 23-August 4, 1990}

Investigators: J.R. Rastorfer, G.D. Van Dyke, and J.E. Frelichowski.

Activities: Cover-class values were recorded at the two sites for the understory species and other environmental components (e.g., logs, stumps, and mineral soil) in 40 quadrats on each of 14 transects. At each site, three transects were on the ROW and the remaining four transects were within the forested portions. The numbers of tree and shrub seedlings and bramble and vine shoots were also recorded. Data from a total of 560 quadrats were collected. Individual shrubs and trees were relocated in the $10 \times 10-\mathrm{m}$ plots using the plot maps made during the August 1989 sampling. A few questionable identifications and diameter measurements were either confirmed or 
corrected. The major significance of this re-examination was in providing insights into the morphological range of green ash and into the red maple/silver maple and pin oak/red oak population complexes. Several trees, especially those along the northern boundary of the ROW, had died since the August 1989 data collection. The bryophyte synusia were sampled along a transect of the ROW segment at each site. A total of 201 sample points were checked at each site, and 115 samples were collected at Site 1 and 69 samples were collected at Site 2. 


\section{Results and Discussion}

Voucher specimens of most plant species found on the sites and nearby areas were collected starting in October 1988 and during the 1989 and 1990 growing seasons. Herbarium specimens were prepared for more than 200 vascular plant species. Vegetational data to determine dominance, density, and frequency were collected from the ROW and adjacent forest communities at each site during the 1989 and 1990 growing seasons. Cover-class values on the percentage of ground covered by standing water within the forest communities were recorded during June of 1989 and 1990 at each site. Soil samples were collected at each site for laboratory analyses. Although data reduction and data analyses are still in progress, the following preliminary data interpretations, results, and observations are provided.

The Federal Interagency Committee for Wetland Delineation (1989) established the soil, hydrologic, and vegetation requirements that have to be met for an area to be classified as a jurisdictional wetlands; these are defined in its wetlands manual. A preliminary analysis of the data collected indicated that the forested portions of both sites qualify as jurisdictional wetlands. One requirement is that the soil be hydric. Both sites have been mapped as the Lenawee silty clay loam by Hutchinson (1979), and Lenawee soils are classified as hydric (number 2B2 or 3) by the USDA Soil Conservation Service (1987). A field inspection of the soils using a 5-cm-diameter orchard auger revealed that the profiles appeared to match that of the Lenawee soil. Another requirement for a jurisdictional wetland is that standing water must stay on the soil surface for at least seven days in a row. Field observations verified that both sites had standing surface water during April, May, and June in 1989. On June 12,1989, standing water covered $18.1 \%$ of the ground surface at Site 1 and $75.8 \%$ of the ground surface at Site 2. These observations indicate that both sites meet the soil and hydrologic criteria for jurisdictional wetlands as defined in the wetlands manual.

Although species dominance (on the basis of coverage, density, or basal areas) must be determined before one can ascertain whether the hydrophytic vegetation criterion for jurisdictional wetlands is met, it seems likely that both sites meet this criterion. Collection data from 1989 for Site 1 indicate that $62 \%$ of the species found in the forested wetland (81 species in number) are classified in the wetlands manual as obligate wetland (OBL), facultative wetland (FACW), or facultative wetland or nonwetland (FAC) species. Collection data from 1989 for the forested wetland of Site 2 indicate that $61 \%$ of the species ( 73 species in number) were OBL, FACW, or FAC species (Table 1). It seems likely that the vegetation in the forested portion of each site will meet the hydrophytic vegetation criterion established for jurisdictional wetlands, because only $50 \%$ of the dominants must fall in these three categories to meet this criterion. It also seems likely that the forested wetland portion of each site will generally fit the classification of palustrine, forested, deciduous, seasonally flooded (PFO1C) as given by Cowardin et al. (1979). Table 2 (which appears after the text of this section) lists the plant species found at the sites and in the adjacent areas, their wetland classification, and habit.

A preliminary analysis of data collected during the 1989 and 1990 growing seasons from the ROW at Site 1 indicates that 18 of 30 species or $60 \%$ are classified as OBL, FACW, or FAC. Of these 18, 10 are introduced agronomic species, of which 1 is FACW, 3 are FAC, and 6 are 
TABLE 1 Number of Species in the Forested and Right-of-Way Portions of Sites 1 and 2, by Indicator Category

\begin{tabular}{|c|c|c|c|c|c|c|c|}
\hline \multirow[b]{2}{*}{ Site } & \multirow[b]{2}{*}{ Location } & \multirow[b]{2}{*}{ Totalb } & \multicolumn{5}{|c|}{ Indicator Category ${ }^{a}$} \\
\hline & & & OBL & FACW & FAC & FACU & UPL \\
\hline 1 & Forested wetland & 131 & 19 & 39 & 23 & 32 & 18 \\
\hline 2 & Forested wetland & 114 & 15 & 34 & 20 & 27 & 18 \\
\hline 1 & Right-of-way & 30 & 8 & 4 & 6 & 9 & 3 \\
\hline 2 & Right-of-way & 25 & 8 & 4 & 6 & 5 & 2 \\
\hline
\end{tabular}

aWetland indicator categories are from Reed (1988): $O B L=$ obligate wetland, FACW $=$ facultative wetland, FAC $=$ facultative wetlands or nonwetlands, FACU = facultative upland, and UPL = obligate upland.

bThe numbers of species are based on specimen collection data from 1989 for the forested portions and from 1989 and 1990 for the right-of-way portions.

FACU. At Site 2, 18 of 25 species or $72 \%$ are classified as OBL, FACW, FAC (Table 1). Of these 18,8 are introduced agronomic species, of which 1 is FACW, 3 are FAC, and 4 are FACU. Some of the introduced species are from a seed mixture applied to the ROW and some are weedy species that invaded from surrounding areas. None of the seeded species at either site are OBL, and only one species at each site is FACW. The seeded and weedy species detract from the wetland characteristics of the ROW. Table 3 (which appears at the end of this section) lists the plant species found on the ROW at the sites and on the adjacent ROW segments, their wetland classification, and habit. A final determination of the ROWs' wetland status will be made after additional data collection and analyses.

Cover-class data were collected at each site during June and August of 1989 and August of 1990. Woody stem counts were made in each $1 \times 1-\mathrm{m}$ quadrat sampled, and measurements of stems $\geq 2 \mathrm{~cm}$ dbh were recorded for each tree in $10 \times 10-\mathrm{m}$ piots during August of each year. Analysis of these data will provide a baseline to measure future changes and distinguish the longterm influences of the ROW from influences due to year-to-year climatic influences. Several additional years of data collection will be required to determine the initial impacts of the ROW on the forest.

As described previously under pipeline construction, logs and soil from clearing and trenching activities had spilled a short distance into edge of the adjacent forest at Site 2 . Attempts to recover the soil that had spilled into the row of logs resulted in them being pushed farther into the forest. Some of the soil remained among the logs, resulting in reduced amounts for backfilling. The row of logs also has both direct and indirect effects on the establishment of vegetation on the ROW. The logs exclude vegetation from the space they occupy and shade some 
of the ROW soil. ROW vegetation has also been disturbed by traffic, mostly four-wheel-drive trucks involved in scavenging firewood from the row of logs. Presently, it is uncertain whether the logs and soil remaining in the row of logs will affect the local hydrology enough to cause vegetational changes. Nevertheless, any adverse effects from the row of logs could have been avoided if all the logs would have been removed from the site during clearing operations.

Another practice that should be monitored carefully during pipeline construction is the discharge of water pumped from the pine ditch. At both Sites 1 and 2, some of this water was discharged sufficiently close to the edge of the forest to cause soil erosion and deposition in the edge of the forest.

In the ROW clearing procedure, stumps that did not interfere with construction activities were left rooted. As a result, some of the stumps resprouted. In addition, areas immediaiely around these stumps were protected, allowing some formally forest understory species to survive on the ROW. Moreover, the minimal time between ditching and backfilling allowed plant propagules to survive in the excavated soil and regenerate following ROW cleanup operations. Hand seeding the ROW without complete tillage allowed the survival and resprouting of some native species while providing ground cover for erosion control on the ROW. General observations incicate that during the second year of growth, seeded species (especially Agrostis gigantea) and species of Eurasian origin were much more evident on the ROW than native species. Additional data collections are necessary to determine the long-term effect of seeded and weedy species on the vegetative community of the ROW. Although numerous native species were present on the ROW, changes in their relative dominance can be determined only after the collection and analysis of cover-class data for several years. 
TABLE 2 Provisional List of Plants Found at Sites 1 and 2 and Surrounding Areas, Midland County, October 1988-October 1989

\begin{tabular}{|c|c|c|c|c|}
\hline Species Name ${ }^{a}$ & Common Name & $\begin{array}{l}\text { Region } 3 \\
\text { Wetland } \\
\text { Index } b\end{array}$ & $\begin{array}{l}\text { Plant } \\
\text { HabitC }\end{array}$ & $\begin{array}{c}\text { Sites } \\
\text { Where } \\
\text { Recorded d }\end{array}$ \\
\hline Acer rubrum & Red maple & FAC & NT & 1,2 \\
\hline Achillea millefolium & Cominon yarrow & FACU & PNF & \\
\hline Actaea pachypoda & White baneberry & & & 2 \\
\hline Actaea rubra & Red baneberry & & & 1 \\
\hline Agrimonia gryposepala & Tall hairy grovebur & FACU+ & PNF & \\
\hline Alisma plantago-aquatica & Broad-leaf water plantain & OBL & PNEF & \\
\hline Alnus rugosa & Speckled alder & OBL & NT & 1,2 \\
\hline Amelanchier arborea & Downy serviceberry & FACU & NT & 1,2 \\
\hline Amelanchier bartramiana & Bartram's serviceberry & FAC & NS & \\
\hline Amphicarpaea bracteata & American hog-peanut & FAC & APNFV & 1,2 \\
\hline Anemone quinquefolia & American woodland thimble-weed & FAC* & PNF & 2 \\
\hline Anemone virginiana & Tall thimble-weed & NI & PNF & \\
\hline Apocynum androsaemifolium & Spreading dogbane & & & \\
\hline Apocynum sibiricum & Prairie dogbane & $\mathrm{FAC}+$ & PNF & \\
\hline Aralia nudicaulis & Wild sarsparilla & FACU & PNF & 1,2 \\
\hline Aralia racemosa & Spikenard & & & 1,2 \\
\hline Arisaema triphyllum & Swamp jack-in-the-pulpit & FACW- & PNF & 2 \\
\hline Asclepias incarnata & Swamp milkweed & OBL & PNF & \\
\hline Aster lateriflorus & Calico aster & FACW- & PNF & 1,2 \\
\hline Aster ontarionis & Ontario aster & FAC & PNF & 1,2 \\
\hline $\begin{array}{l}\text { Aster puniceus var. firmus } \\
\text { (=A. lucidulus) }\end{array}$ & Shiny aster & FACW+ & PNF & 1 \\
\hline Aster sagittifolius & Arrow-leaved aster & & & \\
\hline $\begin{array}{l}\text { Aster simplex var. interior } \\
(=A \text {. simplex })\end{array}$ & Panicled aster & FACW & PNF & 1 \\
\hline Aster umbellatus & Flat-top white aster & FACW & PNF & 1,2 \\
\hline Athyrium filix-femina & Subartic lady fern & FAC & PNF3 & 1,2 \\
\hline Betula papyrifera & Paper birch & FACU+ & NT & 1,2 \\
\hline Botrychium virginianum & Rattlesnake fern & FACU & PNF3 & \\
\hline Brachyelytrum erectum & Brachyelytrum & & & 1,2 \\
\hline Calamagrostis canadensis & Blue-joint reedgrass & $\mathrm{OBL}$ & PNG & 1,2 \\
\hline Carex bromoides & Brome-like sedge & FACW+ & PNGL & 1,2 \\
\hline Carex crinita & Fringed sedge & FACW+ & PNEGL & 1,2 \\
\hline Carex cristatella & Crested sedge & FACW+ & PNEGL & 1,2 \\
\hline Carex gracillima & Graceful sedge & FACU* & PNGL & 1,2 \\
\hline Carex intumescens & Bladder sedge & FACW+ & PNGL & 1,2 \\
\hline
\end{tabular}


TABLE 2 (Cont'd)

\begin{tabular}{|c|c|c|c|c|}
\hline Species Name ${ }^{a}$ & Common Name & $\begin{array}{l}\text { Region } 3 \\
\text { Wetland } \\
\text { Index }\end{array}$ & $\begin{array}{l}\text { Plant } \\
\text { Habitc }\end{array}$ & $\begin{array}{c}\text { Sites } \\
\text { Where } \\
\text { Recorded d }\end{array}$ \\
\hline Carex lacustris & Lakebank sedge & OBL & PNEGL & 1 \\
\hline Carex Iupulina & Hop sedge & OBL & PNEGL & 1,2 \\
\hline Carex normalis & Larger straw sedge & FACW & PNGL & 1,2 \\
\hline Carex pedunculata & Peduncled sedge & & & 2 \\
\hline Carex rosea & Rose-like sedge & & & 1,2 \\
\hline Carex scoparia & Pointed broom sedge & FACW & PNGL & 1 \\
\hline Carex stipata & Crowded sedge & & & 1,2 \\
\hline Carex stricta & Uptight sedge & OBL & PNEGL & 1 \\
\hline Carex tenera & Slender sedge & $\mathrm{FAC}+$ & PNGL & 1,2 \\
\hline Carex tuckermanii & Tuckerman's sedge & OBL & PNGL & 1,2 \\
\hline Carpinus caroliniana & American hornbean & FAC & NT & 1,2 \\
\hline Centaurea maculosa & Spotted knapweed & & & \\
\hline Cephalanthus occidentalis & Common buttonbush & OBL & NT & \\
\hline Cicuta maculata & Spotted water-hemlock & OBL & PNF & 1,2 \\
\hline Cinna arundinacea & Stout wood-reedgrass & FACW & PNG & 1,2 \\
\hline Circaea lutetiana & $\begin{array}{l}\text { Southern broad-leaf Enchanter's } \\
\text { nightshade }\end{array}$ & FACU & PNF & 1 \\
\hline Cirsium anvense & Creeping thistle & FACU & BIF & 1 \\
\hline Cirsium vulgare & Bull thistle & FACU- & BIF & 1,2 \\
\hline Clintonia borealis & Blue breadlily & $\mathrm{FAC}+$ & PNF & 1,2 \\
\hline Conyza canadensis & Canada horseweed & FAC- & ANF & 1 \\
\hline Cornus canadensis & Canada bunchberry & FAC & NS & 1,2 \\
\hline Cornus foemina & Stiff dogwood & FACW- & NS & 1,2 \\
\hline Cornus stolonifera & Red-osier dogwood & FACW & NS & 1 \\
\hline Crataegus punctata & Dotted hawthorn & & & 1,2 \\
\hline Crataegus sp. & Hawthorn & & & \\
\hline Cryptotaenia canadensis & Canada honewort & FAC & PNF & \\
\hline Cypripiedium acaule & Pink lady's slipper & FACW & PNF & \\
\hline Cypripiedium calceolus & Small yellow lady's slipper & $\mathrm{FAC}+$ & PNF & 1 \\
\hline Desmodium candense & Showy tick trefoil & FAC- & PNF & 1 \\
\hline Desmodium glutinosum & Pointed-leaved tick trefoil & & & 1,2 \\
\hline Dienvilla lonicera & Northern bush honeysuckle & & & 1 \\
\hline $\begin{array}{l}\text { Dryopteris austriaca var. } \\
\text { spinulosa }(=D \text {. dilatata) }\end{array}$ & Mountain woodfern & FAC & PNF3 & 1,2 \\
\hline Echinochloa crusgalli & Barnyard grass & FACW & $A I G$ & \\
\hline Elymus virginicus & Virginia wild-rye & FACW- & PNG & 1,2 \\
\hline Epilobium ciliatum & Hairy willow-herb & FACU & PNF & 1 \\
\hline
\end{tabular}


TABLE 2 (Cont'd)

\begin{tabular}{|c|c|c|c|c|}
\hline Species Name ${ }^{a}$ & Common Name & $\begin{array}{l}\text { Region } 3 \\
\text { Wetland } \\
\text { Index }\end{array}$ & $\begin{array}{l}\text { Plant } \\
\text { Habitc }\end{array}$ & $\begin{array}{c}\text { Sites } \\
\text { Where } \\
\text { Recorded d }\end{array}$ \\
\hline Epilobium coloratum & Purple-leaf willow-herb & OBL & PNF & 1,2 \\
\hline Equisetum arvense & Field horsetail & FAC & $\mathrm{PNH} 2$ & 2 \\
\hline Erigeron philadelphicus & Philadelphia fleabane & FACW & BNF & 2 \\
\hline Erigeron strigosus & Prairie fleabane & FAC- & ANF & \\
\hline Euonymus obovata & Running strawberry bush & & & 1,2 \\
\hline Eupatorium perfoliatum & Common boneset & FACW+ & PNF & 1,2 \\
\hline Fagus grandifolia & American beech & FACU & NT & 1 \\
\hline Festuca obtusa & Nodding fescue & FACU+ & PNG & 1,2 \\
\hline Fragaria virginiana & Virginia strawberry & FAC- & PNF & 1,2 \\
\hline $\begin{array}{l}\text { Fraxinus pennsylvanica } \\
\text { var. subintegerrima }\end{array}$ & Green ash & FACW & NT & 1,2 \\
\hline Galium asprellum & Rough bedstraw & OBL & PNF & 1,2 \\
\hline Galium obtusum & Blunt-leaf bedstraw & $\mathrm{FACW}_{+}$ & PNF & 1,2 \\
\hline Galium triflorum & Sweet-scent bedstraw & FACU+ & PNF & 1,2 \\
\hline Gaultheria procumbens & Teaberry & FACU & NS & 1,2 \\
\hline Geranium maculatum & Purple crane's bill & FACU & PNF & 1,2 \\
\hline Glyceria striata & Fowl manna grass & OBL & PNEG & 1,2 \\
\hline Hamamelis virginiana & American witch-hazel & FACU & NST & \\
\hline Helianthus giganteus & Tall sunflower & FACW & PNF & 2 \\
\hline Hieracium aurantiacum & Orange hawkweed & & & \\
\hline Hypericum perforatum & Common St. John's-wort & & & \\
\hline Ilex verticillata & Common winterberry & FACU+ & NTS & 1,2 \\
\hline Iris virginica & Virginia blueflag & OBL & PNF & 1 \\
\hline Juglans nigra & Black walnut & FACU & NT & \\
\hline Juncus articulatus & Jointed rush & OBL & PNGL & \\
\hline Junn:1; brevicaudatus & Narrow-panicle rush & OBL & PNGL & \\
\hline juncus bufonius & Toad rush & FACW+ & ANGL & \\
\hline $\begin{array}{l}\text { Lilium michiganense } \\
(=L . \text { canadense })\end{array}$ & Canada lily & $\mathrm{FAC}+$ & PNF & 2 \\
\hline Lolium perenne & Perennial ryegrass & FACU & PIG & 1,2 \\
\hline Lonicera dioica & Mountain honeysuckle & FACU & NWV & 1,2 \\
\hline Lotus corniculata & Birds-foot trefoil & FAC- & PIF & 1,2 \\
\hline Lycopodium clavatum & Running pine & FAC & PNC & \\
\hline Lycopodium obscurum & Tree clubmoss & FACU & PNC & 2 \\
\hline Lycopodium tristachyum & Ground pine & & & \\
\hline Lycopus americanus & American bugleweed & OBL & PNF & 1,2 \\
\hline Lycopus virginicus & Virginia bugleweed & OBL & PNF & 1,2 \\
\hline Maianthemum canadense & Wild lily-of-the-valley & FAC & PNF & 1,2 \\
\hline
\end{tabular}


TABLE 2 (Cont'd)

\begin{tabular}{|c|c|c|c|c|}
\hline Species Namea & Common Name & $\begin{array}{l}\text { Region } 3 \\
\text { Wetland } \\
\text { Index }{ }^{b}\end{array}$ & $\begin{array}{l}\text { Plant } \\
\text { Habitc }\end{array}$ & $\begin{array}{c}\text { Sites } \\
\text { Where } \\
\text { Recorded d }\end{array}$ \\
\hline Medeola virginiana & Indian cucumber root & & & 1,2 \\
\hline Melampyrum lineare & American cow-wheat & FAC- & AlF & \\
\hline Mentha arvensis & Field mint & FACW & PNF & \\
\hline Mimulus ringens & Allegheny monkey-flower & OBL & PNF & \\
\hline Mitella diphylla & Two-leaf bishop's-cap & FACU+ & PNF & 1,2 \\
\hline Mollugo verticillata & Green carpet-weed & FAC & ANF & \\
\hline Monarda fistulosa & Wild bergamot & FACU & PNF & \\
\hline Muhlenbergia mexicana & Mexican muhly & FACW & PNG & 1,2 \\
\hline $\begin{array}{l}\text { Naumbergia thyrsiflora } \\
(=\text { Lysimachia thyrisiflora) }\end{array}$ & Tufted loosestrife & OBL & PIF & 1,2 \\
\hline Onoclea sensibilis & Sensitive fern & FACW & PNEF3 & 1,2 \\
\hline Osmorhiza claytonii & Hairy sweetcicely & FACU- & PNF & 1 \\
\hline Osmorhiza longistylis & Smoother sweetcicely & FACU- & PNF & 1,2 \\
\hline Osmunda cinnamomea & Cinnamon fern & FACW & PNEF3 & 2 \\
\hline Osmunda regalis & Royal fern & OBL & PNF3 & 1,2 \\
\hline Ostrya virginiana & Eastern hop-hornbean & FACU & NT & 1 \\
\hline $\begin{array}{l}\text { Oxalis fontana } \\
(=0 . \text { europaea })\end{array}$ & Upright yellow wood sorrel & FACU & PIF & 1 \\
\hline Oxalis stricta & Yellow wood sorrel & & & \\
\hline $\begin{array}{l}\text { Panicum boreale } \\
\text { (=Diachanthelium boreale) }\end{array}$ & Northern witch grass & FACU+ & PNG & 1 \\
\hline Parthenocissus quinquefolia & Virginia creeper & FAC- & NWV & 1,2 \\
\hline Penthorum sedoides & Ditch-stonecrop & OBL & PNF & \\
\hline Phalaris arundinacea & Reed canary grass & FACW+ & PNG & \\
\hline Phleum pratense & Timothy & FACU & PIG & 1,2 \\
\hline Plantago rugelii & Black-seeded plantain & FAC & PNF & 1,2 \\
\hline Poa palustris & Fowl bluegrass & FACW+ & PNG & 1 \\
\hline Poa pratensis & Kentucky bluegrass & FAC- & PNG & 1,2 \\
\hline Podophyllum peltatum & Mayapple & FACU & PNF & 2 \\
\hline Polygala paucifolia & Gay wings & FACU & PNF & 1,2 \\
\hline Polygonatum pubescens & Hairy Solomon's-seal & & & 1,2 \\
\hline Polygonum pensylvanicum & Pennsylvania smartweed & FACW+ & ANEF & \\
\hline Polygonum virginianum & Virginia knotweed & FAC & APNF & \\
\hline Populus deltoides & Eastern coltonwood & $\mathrm{FAC}+$ & NT & 1,2 \\
\hline Populus grandidentata & Big-tooth aspen & FACU & NT & 1 \\
\hline Populus tremuloides & Quaking aspen & FAC & & 1,2 \\
\hline Potentilla simplex & Old field cinquefoil & FACU- & PNF & \\
\hline Prenanthes altissima & Tall rattlesnake-root & FACU & PNF & 1,2 \\
\hline
\end{tabular}


TABLE 2 (Cont'd)

\begin{tabular}{|c|c|c|c|c|}
\hline Species Name ${ }^{a}$ & Common Name & $\begin{array}{l}\text { Region } 3 \\
\text { Wetland } \\
\text { Index }\end{array}$ & $\begin{array}{l}\text { Plant } \\
\text { Habitc }\end{array}$ & $\begin{array}{c}\text { Sites } \\
\text { Where } \\
\text { Recorded d }\end{array}$ \\
\hline Prunella vulgaris & Heal-all & FAC & PIF & 1 \\
\hline Prunus pensylvanica & Fire cherry & FACU-* & NST & 2 \\
\hline Prunus serotina & Black cherry & FACU & NT & 1 \\
\hline Prunus virginiana & Choke cherry & FAC- & NST & 1,2 \\
\hline Pteridium aquilinum & Bracken fern & FACU & PNF3 & 1,2 \\
\hline Pyrola elliptica & Shinleaf & & & 1 \\
\hline Quercus bicolor & Swamp white oak & FACW+ & NT & 1,2 \\
\hline Quercus rubra var. borealis & Northern red oak & FACU & NT & 1,2 \\
\hline Ranunculus abortivis & Subalpine butter-cup & FACW- & BPNF & 2 \\
\hline Ranunculus pensylvanicus & Pennsylvania butter-cup & OBL & APNEF & \\
\hline Ranunculus recurvatus & Hooked butter-cup & FACW & PNF & 1,2 \\
\hline Rhamnus alnifolia & Alder-leaf buckthorn & OBL & NS & 2 \\
\hline Ribes americanum & Wild black currant & FACW & NS & 1,2 \\
\hline Ribes cynosbati & Prickly gooseberry & & & 1,2 \\
\hline Rorippa palustris & Bog yellowcress & OBL & AR!EF & \\
\hline Rosa palustris & Swamp rose & OBL & NS & 1 \\
\hline Rubus allegheniensis complex & Allegheny blackberry & FACU+ & NS & 1,2 \\
\hline Rubus hispidus & Bristly blackberry & FACW & NS & 1 \\
\hline $\begin{array}{l}\text { Rubus idaeus var. strigosus } \\
\text { (=R. strigosus) }\end{array}$ & Red raspberry & FACW- & PNS & 1,2 \\
\hline Rubus pubescens & Dwart blackberry & FACW+ & PNF & 1,2 \\
\hline Rudbeckia hirta & Black-eyed Susan & FACU & BPNF & \\
\hline Salix amygdaloides & Peach-leaf willow & FACW & NT & 1,2 \\
\hline Salix bebbiana & Bebb willow & FACW+ & NS & 1 \\
\hline Salix discolor & Pussywillow & FACW & NS & \\
\hline Salix exigua & Sandbar willow & OBL & NS & \\
\hline Salix fragilis & Crack willow & $\mathrm{FAC}+$ & $\pi$ & 1,2 \\
\hline Salix rigida & Heart-leaf willow & FACW+ & NS & \\
\hline Sanicula gregaria & Clustered black-snakeroct & $\mathrm{FAC}+$ & PNF & \\
\hline Sanicula marilandica & Black-snakeroot & $\mathrm{NI}$ & PNF & \\
\hline Scirpus atrovirens & Green bulrush & $\mathrm{OBL}$ & PNEGL & 1 \\
\hline Scutellaria lateriflora & Blue skullcap & OBL & PNF & 1,2 \\
\hline Sium suave & Hemlock water-parsnip & OBL & PNEF & \\
\hline Smilacina racemosa & Feathered false-Solomon's-seal & FACU & PNF & 1,2 \\
\hline Smilax tamnoides & Bristly greenbrier & & & 1,2 \\
\hline Solidago altissima & Tall golden-rod & FACU & PNF & \\
\hline Solidago gigantea & Giant golden-rod & FACW & PNF & 1 \\
\hline
\end{tabular}


TABLE 2 (Cont'd)

\begin{tabular}{|c|c|c|c|c|}
\hline Species Name ${ }^{a}$ & Common Name & $\begin{array}{l}\text { Region } 3 \\
\text { Wetland } \\
\text { Index } b\end{array}$ & $\begin{array}{l}\text { Plant } \\
\text { Habitc }\end{array}$ & $\begin{array}{c}\text { Sites } \\
\text { Where } \\
\text { Record } d_{d}^{d}\end{array}$ \\
\hline $\begin{array}{l}\text { Solidago graminifolia } \\
\text { (=Euthamia graminifolia) }\end{array}$ & Flat-top fragrant golden-rod & FACW- & PNF & 1 \\
\hline Solidago juncea & Early golden-rod & & & \\
\hline Solidago rugosa & Wrinkled golden-rod & FAC+ & PNF & 1,2 \\
\hline Solidago ulmifolia & Elm-leaved golden-rod & & & 1,2 \\
\hline $\begin{array}{l}\text { Sonchus uliginosus } \\
\text { (=S. anensis) }\end{array}$ & Field sowthistle & FAC- & PIF & \\
\hline Spiraea alba & Narrow-leaf meadow-sweet & FACW+ & NS & 1,2 \\
\hline $\begin{array}{l}\text { Steironema ciliatum } \\
\text { (=Lysimachia ciliatum) }\end{array}$ & Fringed loosestrife & FACW & PNF & 1,2 \\
\hline Stellaria longifolia & Long-leaf starwort & FACW+ & PNF & 1 \\
\hline Taraxacum officinale & Common dandelion & FACU & PIF & 1,2 \\
\hline $\begin{array}{l}\text { Thelypteris palustris } \\
(=T . \text { thelypteroides) }\end{array}$ & Marsh fern & FACW+ & F3 & 1,2 \\
\hline Tilia americana & American basswood & FACU & NT & 1,2 \\
\hline Toxicodendron radicans & Poison ivy & $\mathrm{FAC}+$ & NWVS & 1,2 \\
\hline Trientalis borealis & American starfloner & $\mathrm{FAC}+$ & PNF & 1 \\
\hline Trifolium repens & White clover & FACU+ & PIF & 1,2 \\
\hline Trillium grandiflorum & Large-flowered trillium & & & 1,2 \\
\hline Ulmus americana & American elm & FACW- & NT & 1,2 \\
\hline Uvularia grandiflora & Large-flowered bellwort & & & 2 \\
\hline Vaccinium corymbosum & Highbush blueberry & FACW & NS & 1,2 \\
\hline Verbena hastata & Blue vervain & $\mathrm{FACW}+$ & PNF & 1,2 \\
\hline Viburnum acerifolium & Maple-leaved arrowwood & & & 1 \\
\hline Viburnum cassinoides & Withe-rod & FACW & NS & 1,2 \\
\hline Viburnum lentago & Nannyberry & $\mathrm{FAC}+$ & NTS & 1,2 \\
\hline Viola blanda var. palustris & Sweet white violet & FACW- & PNF & 1,2 \\
\hline Viola conspersa & American dog violet & FACW- & PNF & 1,2 \\
\hline Viola macloskeyi & Smooth white violet & & & 2 \\
\hline Viola pubescens & Downy yellow violet & FACU- & PNF & 1,2 \\
\hline Vitis riparia & River-bank grape & FACW- & NWV & 1,2 \\
\hline
\end{tabular}




\section{TABLE 2 (Cont'd)}

Footnotes:

aNames in parentheses indicate synonyms used in Reed (1988).

bRegion 3 indicator categories are from Reed (1988) as follows:

FAC = Facultative, equally likely to occur in wetlands or nonwetlands.

FACU = Facultative upland, usually occur in nonwetlands but occasionally found in wetlands.

FACW = Facultative wetland, usually occur in wetlands but occasionally found in nonwetlands.

$\mathrm{NI}=$ No indicator, insufficient information available to determine an indicator status.

$\mathrm{OBL}=$ Obligate wetland, almost always occur in wetlands under natural conditions.

+ following an indicator indicates a frequency toward the high end of the category (more frequently found in wetlands).

- following an indicator indicates a frequency toward the low end of the category (less frequently found in wetlands).

* identifies tentative assignments.

CPlant habit codes are as follows:
$A=$ Annual
$B=$ Biennial
$\mathrm{C}=$ Clubmoss
$E=$ Emergent
$F=$ Forb
$\mathrm{F3}=$ Fern
$\mathrm{G}=$ Grass
$\mathrm{GL}=$ Grasslike Cyperaceae
$H=$ Partly woody

$H S=$ Half shrub

$\mathrm{H2}=$ t'orsetail

1 = Introduced

$\mathrm{N}=$ Native

$P=$ Perennial

$S=$ Shrub

$T=$ Tree

$V=$ Herbaceous vine and Juncaceae

$W V=$ Woody vine

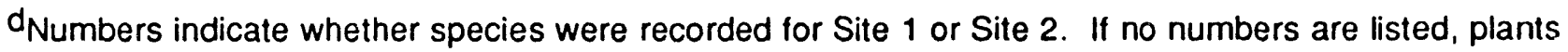
were recorded for surrounding areas but not within study sites. 
TABLE 3 Provisional List of Plants Found on the Right-of-Way, Midland County, July 1989-August 1990

\begin{tabular}{|c|c|c|c|c|}
\hline Species Name ${ }^{a}$ & Common Name & $\begin{array}{l}\text { Region } 3 \\
\text { Wetland } \\
\text { Index } b\end{array}$ & $\begin{array}{l}\text { Plant } \\
\text { Habitc }\end{array}$ & $\begin{array}{c}\text { Sites } \\
\text { Where } \\
\text { Recorded d }\end{array}$ \\
\hline Achillia millefolium & Common yarrow & FACU & PNF & 1 \\
\hline Agrimonia gryposepala & Hainy tall groovebur & FACU+ & PNF & \\
\hline Agrostis gigantea & Black bent grass & $\mathrm{NI}$ & PNG & $1,2^{e}$ \\
\hline Alisma plantago-aquatica & Broad-leaf water plantain & OBL & PNEF & \\
\hline Ambrosia artemisiifolia & Annual ragweed & FACU & ANF & 1,2 \\
\hline Asclepias incarnata & Swamp milkweed & OBL & PNF & \\
\hline Aster graminifolia & Aster & & & 2 \\
\hline Bromus inermis & Smooth brome & & & 2 \\
\hline Bromus japonicus & Japanese brome & FACU & AlG & \\
\hline Carex vulpinoidea & Fox sedge & OBL & PNEGL & 1,2 \\
\hline Centaurea maculosa & Spotted knapweed & & & \\
\hline $\begin{array}{l}\text { Cerastium fontanum } \\
(=C . \text { vulgatum })\end{array}$ & Common mouse-ear chickweed & FACU & PIF & \\
\hline Circea lutetiana & $\begin{array}{l}\text { Southern broad-leaf Enchanter's } \\
\text { nightshade }\end{array}$ & FACU & PNF & 1 \\
\hline Cirsium arvense & Creeping thistle & FACU & PIF & $1,2^{e}$ \\
\hline Cirsium vulgare & Bull thistle & FACU- & BIF & $1 e$ \\
\hline Conyza canadensis & Canada horseweed & FAC- & ANF & $1,2^{e}$ \\
\hline Dactylis glomerata & Orchard grass & FACU & $\mathrm{PIG}$ & \\
\hline Echinochloa crusgalli & Barnyard grass & FACW & AlG & 1,2 \\
\hline Eleocharis obtusa & Blunt spikerush & OBL & APNEGL & \\
\hline Erigeron philadelphicus & Philadelphia fleabane & FACW & BIF & \\
\hline Erigeron strigosus & Prairie fleabane & FAC- & ANF & \\
\hline Eupatorium perfoliatum & Common boneset & FACW+ & PNJF & $1,2^{e}$ \\
\hline Festuca arundinacea & Kentucky fescue & FACU+ & PIG & 1,2 \\
\hline Glyceria striata & Fowl manna grass & OBL & PNEG & 1,2 \\
\hline Hieracium auranthiacum & Orange hawkweed & & & \\
\hline Hieracium florentinum & & & & \\
\hline Hieracium pratense & & & & \\
\hline Hypericum majus & Large Canadian St. John's-wort & FACW & ANF & \\
\hline Hypericum perforatum & Common St. John's-wort & & & \\
\hline Juncus articulatus & Jointed rush & OBL & PNGL & $1,2^{e}$ \\
\hline Juncus brevicaudata & Narrow-panicle rush & OBL & PNGL & \\
\hline Juncus bufonius & Toad rush & $\mathrm{FACW}_{+}$ & ANGL & 1,2 \\
\hline Juncus effusus & Soft rush & OBL & PNEGL & \\
\hline Lobelia cardinalis & Cardinal flower & OBL & PNF & $2^{e}$ \\
\hline
\end{tabular}


TABLE 3 (Cont'd)

\begin{tabular}{|c|c|c|c|c|}
\hline Species Name ${ }^{a}$ & Common Name & $\begin{array}{l}\text { Region } 3 \\
\text { Wetland } \\
\text { Index } b\end{array}$ & $\begin{array}{l}\text { Plant } \\
\text { Habitc }\end{array}$ & $\begin{array}{c}\text { Sites } \\
\text { Where } \\
\text { Recorded d }\end{array}$ \\
\hline Lolium perenne & Perennial ryegrass & FACU & PIG & $1,2^{e}$ \\
\hline Lotus corniculata & Birds-foot trefoil & FAC- & PIF & $1,2^{e}$ \\
\hline Medicago Iupulina & Black medic & FAC- & AlF & \\
\hline Melampyrum lineare & American cow-wheat & FAC- & AIF & \\
\hline Mimulus ringens & Allegheny monkey-flower & OBL & PNF & $1^{e}$ \\
\hline $\begin{array}{l}\text { Panicum implicatum } \\
\text { (=Dichanthelium } \\
\text { acuminatum) }\end{array}$ & Panic grass & FAC & PNG & $1,2^{e}$ \\
\hline Penthorum sedoides & Ditch-stonecrop & OBL & PNF & $1,2^{e}$ \\
\hline Phleum pratense & Timothy & FACU & PIG & 1 \\
\hline Plantago major & Common plantain & $\mathrm{FAC}+$ & PIF & $1,2^{e}$ \\
\hline Poa pratensis & Kentucky bluegrass & FAC- & PNG & \\
\hline Polygonum sp. & & & & $2^{e}$ \\
\hline Potentilla norvegica & Norwegian cinquefoil & FAC & ABPNF & $1,2^{e}$ \\
\hline Potentilla simplex & Old field cinquefoil & FACU- & PNF & \\
\hline Ranunculus pensylvanicus & Pennsylvania butter-cup & OBL & APNEF & \\
\hline Ranunculus recurvatus & Hooked butter-cup & FACW & PNF & \\
\hline Ranunculu's scleratus & Celery-leaf butter-cup & OBL & APNEF & \\
\hline Rorippa palustris & Bog yellow cress & OBL & ANEF & \\
\hline Rudbeckia hirta & Black-eyed susan & FACU & BPNF & ${ }_{1} \mathrm{e}$ \\
\hline Salix amygdaloides & Peach-leaf willow & FACW & NT & $1,2^{e}$ \\
\hline Salix exigua & Sandbar willow & OBL & NS & $1,2^{e}$ \\
\hline Sanicula gregaria & Clustered black-snakeroot & FAC+ & PNF & \\
\hline Sanicula marilandica & Black-snakeroot & $\mathrm{NI}$ & PNF & \\
\hline Scirpus acutus & Hard-stem bulrush & OBL & PNEGL & 1,2 \\
\hline $\begin{array}{l}\text { Solidago graminifolia } \\
\text { (=Euthamia } \\
\text { graminifolia) }\end{array}$ & Flat-top fragrant goldenrod & FACW- & PNF & $1,2^{e}$ \\
\hline Trifolium repens & White clover & FACU+ & PIF & $1,2^{e}$ \\
\hline Typha sp. & Cattail & OBL & PNEF & 1,2 \\
\hline Verbascum thapsus & Common mullein & & & 1 \\
\hline Verbena hastata & Blue vervain & & & 1 \\
\hline
\end{tabular}


TABLE 3 (Cont'd)

Footnotes:

aNames in parentheses indicate synonyms used in Reed (1988).

begion 3 indicator categories are from Reed (1988) as follows:

FAC = Facultative, equally likely to occur in wetlands or nonwetlands.

FACU = Facultative upland, usually occur in nonwetlands but occasionally found in wetlands.

FACW = Facultative wetland, usually occur in wetlands but occasionally found in nonwetlands.

$\mathrm{NI} \quad=$ No indicator, insufficient information available to determine an indicator status.

$\mathrm{OBL}=$ Obligate wetland, almost always occur in wetlands under natural conditions.

+ following an indicator indicates a frequency toward the high end of the category (more frequently found in wetlands).

- following an indicator indicates a frequency toward the low end of the category (less frequently found in wetlands).

* identifies tentative assignments.

CPlant habit codes are as follows:
$A=$ Annual
$B=$ Biennial
$\mathrm{C}=$ Clubmoss
$E=$ Emergent
$\mathrm{F}=$ Forb
$\mathrm{F} 3=$ Fern
$\mathrm{G}=$ Grass
$\mathrm{GL}=$ Grasslike Cyperaceae
$H=$ Partly woody

$H S=$ Half shrub

$\mathrm{H} 2$ = Horsetail

1 = Introduced

$N=$ Native

$P=$ Perennial

$S=$ Shrub

$T=$ Tree

$V=$ Herbaceous vine and Juncaceae

$W V=$ Woody vine

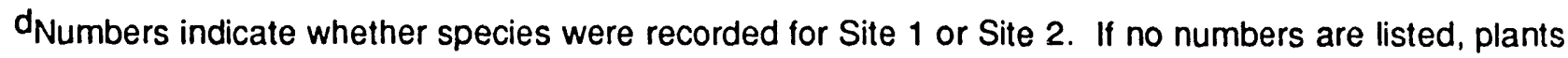
were recorded for surrounding areas but not within study sites.

e Indicates that the plants occurred up to $5 \mathrm{~m}$ north of the ROW in areas of disturbance. 


\section{Recommendations}

Recommendations based on observations made during the first two years of the study are listed here:

1. Construction contracts should ensure that the logs from the ROW are properly removed to avoid potential adverse ecological impacts on native plant communities.

2. Care should be taken to ensure that excavated soil does not spill beyond the boundaries of the ROW, causing adverse ecological impacts in adjacent native plant communities.

3. Water pumped from the pipe ditch should be directed so that it will not cause soil erosion or deposition that could adversely affect adjacent native plant communities.

4. Stumps that were allowed to remain on the ROW, even when cut to ground level, did provide protection to some floristic elements throughout the construction activities. Hence, the policy of removing only those stumps necessary for installation of the pipe should be continued.

5. Seeding the ROW of the study sites was probably unnecessary due to its level topography, poor drainage, and apparently abundant soil reserve of native plant propagules. Seeding areas consisting of native vegetation should only be done when deemed necessary to control erosion. Furthermore, it should be done with native species, if at all possible, and should use methods involving minimal soil disturbance to conserve the soil bank of plant propogules.

An incidental note: During the summer of 1990, it was noted that ditches along county roads just southeast of the study sites were deepened by the county. These deeper ditches could provide increased drainage of the general area and might even lower water levels in the study sites. Pipeline companies should take careful note of any such activities to ensure that any negative impacts on affected wetlands are not attributed to the construction and maintenance of the ROW.

Recommendations for completion of the present phase of this study are as follows:

1. Field data collection should be continued through the 1992 growing season using present procedures, followed by a complete data analysis and the preparation of a report on the initial phase of this study.

2. Recommendations for additional data collection after 1992 should be made on the basis of an analysis of the stage of development of the vegetation on the ROW. The recommendations should include time intervals for such studies (for 
example, every five years) until two successive sets of data indicate that stable communities have formed on the ROW.

3. An analysis of any changes that may have occurred in the edge of the forest adjacent to the ROW should be used to make recommendations for follow-up studies in the forest edge. Again, studies should continue at intervals to be determined until stabilization occurs.

Suggestions for related studies are provided below:

1. Studies comparing the ecological impacts of different ROW maintenance practices on wetland vegetation are needed.

2. Studies on the ecological impacts of off-road vehicles on ROW wetland vegetation should be considered.

3. The ecological impacts of the corduroy (slash) road on the development of wetland vegetation should be studied.

4. Whether or not seeding with introduced agronomic species enhances or retards the development of native vegetation on the ROW needs to be investigated.

5. If negative vegetational impacts are noted in the edge of the forest adjacent to the edge of the ROW because of increased wind and light penetration, studies should be designed to test different ways to minimize such impacts, such as the planting of native shrubs on the ROW adjacent to the forests. 


\section{References}

Albert, D.A., S.R. Denton, and B.V. Barnes, 1986, Regional Landscape Ecosystems of Michigan, School of Natural Resources, University of Michigan, Ann Arbor, Mich.

Arner, D.H., 1960, Effects of Rights-of-Way Techniques on Vegetation, Trans. North American Wildlife Conf., 25:378-386.

Arner, D.H, 1966, Utility Line Right-of-Way Management, Trans. North American Wildlife and Natural Resource Conf., 31:259-268.

Arner, D., 1981, Prescribed Burning in the Utility Rights-of-Way Management, in G.W. Wood, ed., Prescribed Fire and Wildlife in Southern Forests, Belle W. Baruch Forest Science Institute, Clemson University, Georgetown, S.C., pp. 163-166.

Arner, D.H., L.E. Cliburn, D.R. Thomas, and J.D. Manner, 1976, The Use of Fire, Fertilizer and Seed for Right-of-Way Maintenance in the Southeastern United States, in R.E. Tillman, ed., Proc. First ROW Symp., pp. 155-166.

Arner, D.H., J.D. Glover, D.R. Hartley, and J.C. Huntley, 1987, Vegetational Changes on a Right-of-Way after Repetitions of Different Maintenance Treatments, in W.R. Byrnes and H.A. Holt, eds., Proc. Fourth ROW Symp., pp. 133-135.

Barnes, B.V., and W.H. Wagner, Jr., 1981, Michigan Trees, University of Michigan Press, Ann Arbor, Mich.

Billington, C., 1949 (Second Edition), Shrubs of Michigan, Cranbrook Institute of Science, Bloomfield Hills, Mich.

Bonham, C.D., 1989, Measurements for Terrestrial Vegetation, John Wiley and Sons, New York City.

Braun, E.L., 1974 (Facsimile of the 1950 First Edition), Deciduous Forest of Eastern North America, Hafner Press, New York City.

Brown, D., 1987, Growth of Stump Sprouts on a Simulated Right-of-Way, in W.R. Byrnes and H.A. Holt, eds., Proc. Fourth ROW Symp., Vol. XII, pp. 152-157.

Brunnschweiler, D., 1964, Precipitation Regime in the Lower Peninsula of Michigan, in C.M. Davis, ed., Readings in the Geography of Michigan, Ann Arbor Publishers, Ann Arbor, Mich., pp. 49-53.

Byrnes, W.R., and H.A. Holt, eds., 1987, Proceedings: Fourth Symposium on Environmental Concerns in Rights-of-Way Management, October 25-28, 1987, Indianapolis, Ind., published by Department of Forestry and Natural Resources, Purdue University, West Lafayette, Ind. 
Conard, H.S., 1979 (Second Edition Revised by P.L. Redfearn, Jr.), How to Know the Mosses and Liverworts, Wm. C. Brown Company Publishers, Dubuque, Iowa.

Core, E.L., and N.P. Ammous, 1958, Woody Plants in Winter, The Boxwood Press, Pittsburgh.

Cowardin, L.M., V. Carter, F.C. Golet, and E.T. LaRoe, 1979, Classification of Wetlands and Deepwater Habits of the United States, Publication FWS/OBS-79/31, U.S. Department of the Interior, Fish and Wildlife Service, Office of Biological Services.

Crabtree, A.F., ed., 1984, Proceedings of the Third International Symposium on Environmental Concerns in Rights-of-Way Management, February 15-18, 1982, San Diego, California, published by Department of Wildlife and Fisheries, Mississippi State University, Jackson, Miss.

Crum, H., 1983 (Third Edition), Mosses of the Great Lakes Forest, Herbarium, University of Michigan, Ann Arbor, Mich.

Crum, H.A., and L.E. Anderson, 1981a, Mosses of Eastern North America, Volume 1, Columbia University Press, New York City.

Crum, H.A., and L.E. Anderson, 1981b, Mosses of Eastern North America, Volume 2, Columbia University Press, New York, City.

Darlington, H.J., 1945, Taxonomic and Ecological Work on the Higher Plants of Michigan -- Part I: A Brief Account of the Michigan Flora and Botanical Survey and Part II: Bibliography, Technical Bulletin 201, Michigan State College Agriculture Experiment Station, East Lansing, Mich.

Darlington, H.T., 1964, The Mosses of Michigan, Cranbrook Institute of Science, Bloomfield Hills, Mich.

Daubenmire, R., 1968, The Plant Communities (A Textbook of Plant Synecology), Harper and Row, Publishers, New York City.

Davis, C.M., 1964, Readings in the Geography of Michigan, Ann Arbor Publishers, Ann Arbor, Mich.

de Jong, E., and Button, R.G., 1973, Effects of Pipeline Installation on Soil Properties and Productivity, Canadian J. of Soil Science, 53(1):37-47.

Dorr, Jr., J.A., and D.F. Eschman, 1970, Geology of Michigan, University of Michigan Press, Ann Arbor, Mich.

Downey, T., 1976, Emphasizing the Benefits of the Environmental Rehabilitation of Natural Gas Pipeline Rights-of-Way, in R. Tillman, ed., Proc. First ROW Symp., pp. 231-240. 
Egler, F.E., 1954, Vegetation Management for Rights-of-Way and Roadsides, Smithsonian Institution Annual Report, 1953: 299-322.

Eichmeier, A.H., 1964, Climate of Michigan, in C.M. Davis, ed., Readings in the Geography of Michigan, Ann Arbor Publishers, Ann Arbor, Mich., pp. 41-47.

Elliott, J.C., 1953, Composition of Upland Second Growth Hardwood Stands in the Tension Zone of Michigan as Affected by Soils and Man, Ecological Monographs, 23(3):271-288.

Farnworth, E.G., 1981, Natural Revegetation of Tidal Freshwater Marshes Disturbed by Natural Gas Pipeline Construction in Savannah, Georgia, in R.E. Tillman, ed., Proc. Second ROW Symp., pp. 42-1 through 42-29.

Farrand, W.R., 1988, The Glacial Lakes around Michigan, Bulletin 4, Geological Survey Division, Michigan Department of Natural Resources, Lansing, Mich.

Federal Interagency Committee for Wetland Delineation, 1989, Federal Manual for Identifying and Delineating Jurisdictional Wetlands, cooperative technical publication, U.S. Army Corps of Engineers, U.S. Environmental Protection Agency, U.S. Department of the Interior, Fish and Wildlife Service, and U.S. Department of Agriculture, Soil Conservation Service.

Fernald, M.L., 1950 (Eighth Edition), Gray's Manual of Botany, American Book Co., New York City.

Gleason, H.A., 1952a, Illustrated Fora of the Northeastern United States and Adjacent Canada, Volume 1, New York Botanical Garden, New York City.

Gleason, H.A., 1952b, Illustrated Flora of the Northeastern United States and Adjacent Canada, Volume 2, New York Botanical Garden, New York City.

Gleason, H.A., 1952c, Illustrated Flora of the Northeastern United States and Adjacent Canada, Volume 3, New York Botanical Garden, New York City.

Craves, A.H., 1956 (Revised Edition), Illustrated Guide to Trees and Shrubs, Harper and Brothers Publishers, New York City.

Greig-Smith, P., 1964 (Second Edition), Quantitative Plant Ecology, Butterworth and Co., Ltd., London.

Harper, J.L., 1977, Population Biology of Plants, Academic Press, London.

Hithchcock, A.S., 1950 a (Second Edition Revised by A. Chase; First Dover Paperback Published in 1971), Manual of Grasses of the United States, Volume 1, Dover Publications, Inc., New York, City, pp. 1-569. 
Hithchcock, A.S., 1950b (Second Edition Revised by A. Chase; First Dover Paperback Published in 1971), Manual of Grasses of the United States, Volume 2, Dover Publications, Inc., New York City, pp. 570-1051.

Huntley, J.C., and D.H. Arner, 1984, Right-of-Way Maintenance to Reduce Costs and Increase Vegetative Diversity and Wildlife Habitat -- A Demonstration, in A.F. Crabtree, ed., Proc. Third ROW Symp., pp. 342-351.

Hutchison, D.E., 1979, Soil Survey of Midland County, Michigan, U.S. Department of Agriculture, Soil Conservation Service.

Hutnik, R.J., W.C. Bramble, and W.R. Byrnes, 1987, Seedbed Contents on an Electric Transmission Right-of-Way, in W.R. Byrnes and H.A. Holt, eds., Proc. Fourth ROW Symp., pp. 81-88.

Johnson, L., 1984, Revegetation along Pipeline Rights-of-Way in Alaska, in A.F. Crabtree, ed., Proc. Third ROW Symp., pp. 254-264.

Kelly, R.W., 1964, The Glacial Lakes surrounding Michigan, in C.M. Davis, ed., Readings in the Geography of Michigan, Ann Arbor Publishers, Ann Arbor, Mich., pp. 29-38.

Krone, M.W., G.I. Menelsshon, W. Grip, J. Hill, and F. Monteferrante, 1987, Aerial Monitoring of Marsh Regeneration along a Single-and Double-Ditched Pipeline, in W.R. Byrnes and H.A. Holt., eds., Proc. Fourth ROW Symp., pp. 387-410.

Long, S.G., and S.L. Ellis, 1984, Revegetation Guideline Development for Pipeline Rights-ofWay, in A.F. Crabtree, ed., Proc. Third ROW Symp., pp. 233-244.

Magnuson, J.J., 1990, Long-Term Ecological Research and the Invisible Present, BioScience, 40(7):495-501.

Martin, H.M., 1958, Outline of the Geological History of Midland County, Geological Survey Division, Michigan Department of Natural Resources, Lansing, Mich.

Martin, H.M., 1964, The First Four Billion Years, in C.M. Davis, ed., Readings in the Geography of Michigan, Ann Arbor Publishers, Ann Arbor, Mich., pp. 7-27.

Maycock, P.F., and J.T. Curtis, 1960, The Phytosociology of Boreal Conifer -- Hardwood Forests of the Great Lakes Region, Ecological Monographs, 30(1):1-35.

McIntire, G.S., and R. McKee, 1964, 100 Years of Michigan Forests, in C.M. Davis, ed., Readings in the Geography of Michigan, Ann Arbor Publishers, Ann Arbor, Mich., pp. 97-100.

Michigan Department of Natural Resources, 1988a, Michigan's Goemaere-Anderson Wetland Protection Act (1979 Public Act 203 and Administrative Rules), Michigan Department of Natural Resources, Land and Water Management Division, Lansing, Mich. 
Michigan Department of Natural Resources, 1988b, Wetland Protection Guidebook, Michigan Department of Natural Resources, Land and Water Management Division, Lansing, Mich.

Miller, C.E., 1964, Soils of Michigan, in C.M. Davis, ed., Readings in the Geography of Michigan, Ann Arbor Publishers, Ann Arbor, Mich., pp. 57-60.

Mueller-Dombois, D., and H. Ellenberg, 1974, Aims and Methods of Vegetation Ecology, John Wiley and Sons, New York City.

Nickerson, N.H., and F.R. Thibodeau, 1986, The Effect of Power Utility Rights-of-Way on Wetlands, J. of Arboriculture, 12(2):53-55.

Niering, W.A., G.D. Dreyer, F.E. Egler, and R.P. Anderson, Jr., 1986, Stability of a Viburnum Lentago Shrub Community after 30 Years, Torrey Botanical Club Bulletin, 113(1):23-27.

Niering, W.A., and R.H. Goodwin, 1974, Creation of Relatively Stable Shrub Lands with Herbicides: Arresting "Succession" on Rights-of-Way and Pastureland, Ecology, 55:784-795.

Odegard, G.J., J.F. George, J.A. Sproul Jr., and T.M. Sawyer, 1984, Vegetation Recovery of $a$ Pipeline Right-of-Way on a Texas Coastal Barrier Island, in A.F. Crabtree, ed., Proc. Third ROW Symp., pp. 245-253.

Olson, D.P., L. Alexander, and S. Macrigeanis, 1984, Use of Prescribed Burning for Managing Rights-of-Way in Central New England -- Preliminary Results, in A.F. Crabtree, ed., Proc. Third ROW Symp., pp. 428-445.

Porter, C.L., 1967 (Second Edition), Taxonomy of Flowering Plants, W.H. Freeman and Co., San Francisco.

Ranney, J.W., M.C. Bruner, and J.B. Levenson, 1981, The Importance of Edge in the Structure and Dynanics of Forest Islands, in R.L. Burgess and D.M. Sharp, eds., Forest Island Dynamics in Man-Dominated Landscapes, Springer-Verlag, New York City, pp. 67-95.

Reed, Jr., P.B., 1988, National List of Plant Species That Occur in Wetlands: North Central [United States] (Region 3), Biological Report 88 (26.3), U.S. Department of the Interior, Fish and Wildlife Service, Research and Development.

Schuster, R.M, 1966, The Hepaticae and Anthocerotae of North America, Volume 1, Columbia University Press, New York City.

Schuster, R.M., 1969, The Hepaticae and Anthocerotae of North America, Volume 2, Columbia University Press, New York City.

Schuster, R.M., 1974, The Hepaticae and Anthocerotae of North America, Volume 3, Columbia University Press, New York City. 
Schuster, R.M., 1980, The Hepaticae and Anthocerotae of North America, Volume 4, Columbia University Press, New York City.

Secley, D.A., 1964, Factors Controlling Climate, in C.M. Davis, ed., Readings in the Geography of Michigan, Ann Arbor Publishers, Ann Arbor, Mich., pp. 30-40.

Smith, H.V., 1966, Michigan Wildflowers, Cranbrook Institute of Science, Bloomfield Hills, Mich.

Smith, N.F., 1964, Michigan Trees Worth Knowing, in C.M. Davis, ed., Readings in the Geography of Michigan, Ann Arbor Publishers, Ann Arbor, Mich., pp. 89-96.

Spurr, S.H., and B.V. Barnes, 1973 (Second Edition), Forest Ecology, The Ronald Press Co., New York City.

Steere, W.C., 1940, Liverworts of Southern Michigan, Cranbrook Institute of Science, Bloomfield Hills, Mich.

Steinhardt, G.C., W.R. Byrnes, and W.W. McFee, 1987, Soil Compaction Considerations for Right-of-Way Management, in W.R. Byrnes and H.A. Holt, eds., Proc. Fourth ROW Symp., pp. 423-426.

Strommen, N.D., 1974, The Climate of Michigan, in Climates of the States, Volume 1 -- Eastern States Plus Puerto Rico and the U.S. Virgin Islands, U.S. Department of Commerce, Office of the National Oceanic and Atmospheric Administration, Water Information Center, Inc., Port Washington, N.Y., pp. 192-207.

Swink, F., and G. Wilhelm, 1979, Plants of the Chicago Region, Morton Arboretum, Lisle, Ill.

Taylor, J.D., S.D. Zellmer, and R.P. Carter, 1987, Effects of Pipeline Installation on Soil Properties and Crop Production in the Oklahoma Panhandle, in W.R. Byrnes and H.A. Holt, eds., Proc. Fourth ROW Symp., pp. 377-386.

Thibodeau, F.R., and N.H. Nickerson, 1986, Impact of Power Utility Rights-of-Way on Wooded Wetland, Environmental Management, 10(6):809-814.

Tillman, R.E., ed., 1976, Proceedings of the First National Symposium on Environmental Concerns in Rights-of-Way Management, January 6-8, 1976, Mississippi State University, published by Mississippi State University, Jackson, Miss., available from Publications Department, N.Y. Botanical Garden, Bronx, N.Y.

Tillman, R.E., ed., 1981, Environmental Concerns in Rights-of-Way Management: Proceedings of Second Symposium Held October 16-18, 1979, Ann Arbor, Mich., prepared by Mississippi State University, Jackson, Miss., Report EPRI WS-78-141, published by Research Reports Center, Electric Power Research Institute, Palo Alto, Calif., March. 
USDA, Soil Conservation Service, 1987, Hydric Soils of the United States, 1987, U.S. Department of Agriculture in cooperation with the National Technical Committee for Hydric Soils.

Veatch, J.O., 1953, Soils and Land of Michigan, Michigan State College Press, East Lansing, Mich.

Voss, E.G., 1972, Michigan Flora. Part 1 (Gymnosperms and Monocots), Cranbrook Institute of Science, Broomfield Hills, Mich.

Voss, E.G., 1985, Michigan Flora. Part 2 (Dicots), Bulletin 59, University of Michigan and the Cranbrook Institute of Science, Ann Arbor, Mich.

Welch, W.H., 1957, Mosses of Indiana, Division of Forestry, Department of Conservation, Indianapolis, Ind.

Whiteside, E.P., I.F. Schneider, and R.L. Cook, 1963, Soils of Michigan, Special Bulletin 402, Agricultural Experiment Station, Michigan State University, East Lansing, Mich.

Whiteside, E.P., J.F. Schneider, and R.L. Cook, 1964, The Soils of Michigan, in C.M. Davis, ed., Readings in the Geography of Michigan, Ann Arbor Publishers, Ann Arbor, Mich., pp. 61-67.

Zellmer, S.D., and J.D. Taylor, 1988, Erosion Control on a Steeply Sloped Pipeline Right-ofWay in Southwestern Pennsylvania, Report GRI-88/0318, Gas Research Institute, Chicago.

Zellmer, S.D., J.D. Taylor, D.J. Conte, and A.J. Gaynor, 1987, Erosion Control on Steep Slopes following Pipeline Construction, in W.R. Byrnes and H.A. Holt, eds., Proc. Fourth ROW Symp., pp. 359-371. 


\section{Appendix A:}

\section{Description of the Typical Pedon for Lenawee Silty Clay Loam in Midland County}

Ap $\quad 0$ to 9 in.; black (10YR 2/1) silty clay loam, gray (10YR 5/1) dry; moderate fine granular structure; firm; few fine roots; slightly acid; abrupt s.mooth boundary.

B21g 9 to 18 in.; dark grayish brown (10YR 4/2) silty clay loam; few fine prominent yellowish brown $(7.5$ YR 5/6, 5/8) mottles; moderate medium angular blocky structure; firm; few fine roots; slightly acid; clear wavy boundary.

B22g 18 to $25 \mathrm{in}$; light brownish gray (10YR 6/2) silty clay; common medium prominent strong brown $(7.5$ YR $5 / 6,5 / 8)$ mottles; moderate medium angular blocky structure; firm; neutral; gradual wavy boundary.

B23g 25 to 40 in.; grayish brown (10YR 5/2) silty clay; common fine faint light brownish gray (10YR 6/2) and common medium prominent strong brown $(7.5 \mathrm{YR} 5 / 6,5 / 8)$ mottles; massive; very firm; medium acid; clear wavy boundary.

$\mathrm{Clg} 40$ to 46 in.; reddish gray (5YR 5/2) silty clay; common fine prominent light brownish gray $(2.5 \mathrm{Y} 6 / 2)$, strong brown (7.5YR 5/6), and reddish yellow (7.5YR 6/8) mottles; massive; very firm; slight effervescence; mildly alkaline; clear wavy boundary.

C2g 46 to 52 in.; reddish brown (5YR 5/3) silty clay; common fine prominent grayish brown (2.5Y 5/2) and common medium prominent strong brown (7.5YR 5/6) mottles; massive; very firm; strong effervescence; moderately alkaline; clear wavy boundary.

C3g 52 to 60 in.; grayish brown (2.5Y 5/2) silty clay; common medium prominent reddish brown (5YR 5/4) and reddish yellow (5YR 6/6,6/8) mottles; massive; very firm; strong effervescence; moderately alkaline.

The thickness oi the solum ranges from 25 to 50 in. The solum ranges from medium acid to neutral in the A and B21g horizons and from slightly acid to mildly alkaline in the lower part of the B horizon. The clay content in the control section averages between $35 \%$ and $45 \%$.

The A horizon has value of 2 or 3 and chroma of 1 or 2 . It is dominantly silty clay loam but in places is silt loam and loam. Some pedons have an A2 horizon.

The B horizon has hue of 10YR or 7.5YR, value of 4 to 6 , and chroma of 1 or 2 . It is silty clay loam or silty clay and contains thin layers of silt loam, clay, or very fine sand. Some pedons have a B1 horizon.

The C horizon has hue of $5 Y R$ to $10 Y R$, value of 5 or 6 , and chroma of 2 to 6 . It is stratified silt loam to silty clay. Reaction is mildly alkaline or moderately alkaline.

*Source: Hutchison (1979), pg. 36. 


\section{Appendix B:}

\section{Selected Vascular Plants in Lower Michigan}

This is a selected list of vascular plants with distributions in the lower peninsula of Michigan from the transition zone northward or from the transition zone southward (Voss 1972, 1985).

\begin{tabular}{|c|c|c|c|}
\hline Plant Name & Location & Vol. & Page \\
\hline Sparganium angustifolium & $\mathbf{N}$ & 1 & 82 \\
\hline Beckmannia syzigachne & $\mathbf{N}$ & 1 & 206 \\
\hline Carex adusta & $\mathbf{N}$ & 1 & 278 \\
\hline Carex aenea & $\mathbf{N}$ & 1 & 278 \\
\hline Carex houghtoniana & $\mathbf{N}$ & 1 & 310 \\
\hline Scirpus microcarpus & $\mathbf{N}$ & 1 & 358 \\
\hline Calypso bulbosa & $\mathrm{N}$ & 1 & 438 \\
\hline Arceuthobium pusillum & $\mathbf{N}$ & 2 & 100 \\
\hline Arabis caucasica & $\mathrm{N}$ & 2 & 294 \\
\hline Ribes glandulosum & $N$ & 2 & 333 \\
\hline Ribes hudsonianum & $\mathbf{N}$ & 2 & 333 \\
\hline Potentilla tridentata & $\mathbf{N}$ & 2 & 429 \\
\hline Tamarix parviflora & $N$ & 2 & 583 \\
\hline Epilobium palustre & $\mathbf{N}$ & 2 & 621 \\
\hline Juniperus virginiana & $S$ & 1 & 68 \\
\hline Eragrostis pilosa & $S$ & 1 & 122 \\
\hline Briza media & $S$ & 1 & 130 \\
\hline Bromus pubescens & $S$ & 1 & 135 \\
\hline Puccinellia distans & $S$ & 1 & 148 \\
\hline Cinna arundinacea & $S$ & 1 & 198 \\
\hline Leersia virginica & $S$ & 1 & 212 \\
\hline Carex seorsa & $S$ & 1 & 270 \\
\hline Carex muskingumensis & $S$ & 1 & 278 \\
\hline Carex gracilescens & $S$ & 1 & 300 \\
\hline Carex amphibola & $S$ & 1 & 304 \\
\hline Carex swanii & $S$ & 1 & 309 \\
\hline Carex hirsutella & $S$ & 1 & 309 \\
\hline Carex haydenii & $S$ & 1 & 313 \\
\hline Carex emoryi & $S$ & 1 & 315 \\
\hline Carex lupuliformis & $S$ & 1 & 330 \\
\hline Arisaema dracontium & $S$ & 1 & 367 \\
\hline Polygonatum biflorum & $S$ & 1 & 400 \\
\hline Allium canadense & $S$ & 1 & 414 \\
\hline
\end{tabular}




\begin{tabular}{|c|c|c|c|}
\hline Plant Name & Location & Vol. & Page \\
\hline Hypoxis hirsuta & $S$ & 1 & 424 \\
\hline Sisyrinchium atlanticum & $\mathrm{S}$ & 1 & 429 \\
\hline Habenaria ciliaris & $\mathbf{S}$ & 1 & 442 \\
\hline Corallorhiza odontorhiza & $S$ & 1 & 452 \\
\hline Liparis liliifolia & $\mathbf{S}$ & 1 & 454 \\
\hline Saururus cernuus & $\mathbf{S}$ & 2 & 40 \\
\hline Salix sericea & $\mathbf{S}$ & 2 & 49 \\
\hline Carya glabra & $\mathbf{S}$ & 2 & 59 \\
\hline Quercus bicolor & $\mathbf{S}$ & 2 & 82 \\
\hline Quercus muehlenbergii & $S$ & 2 & 84 \\
\hline Polygonum virginianum & $S$ & 2 & 119 \\
\hline Polygonum orientale & $S$ & 2 & 123 \\
\hline Chenopodium rubrum & $S$ & 2 & 140 \\
\hline Chenopodium urbicum & $S$ & 2 & 141 \\
\hline Amaranthus tuberculatus & $S$ & 2 & 146 \\
\hline Amaranthus hypochondriacus & $\mathbf{S}$ & 2 & 149 \\
\hline Portulaca grandifl ra & $S$ & 2 & 153 \\
\hline Silene virginica & $S$ & 2 & 183 \\
\hline Nuphar advena & $S$ & 2 & 199 \\
\hline Isopyrum biternatum & $S$ & 2 & 225 \\
\hline Jeffersonia diphylla & $S$ & 2 & 232 \\
\hline Liriodendron tulipifera & $S$ & 2 & 236 \\
\hline Cardamine hirsuta & $S$ & 2 & 285 \\
\hline Arabis laevigata & $S$ & 2 & 295 \\
\hline Sedum ternatum & $\mathrm{S}$ & 2 & 316 \\
\hline Crataegus crus-galli & $\mathrm{S}$ & 2 & 399 \\
\hline Crataegus pruinosa & $\mathrm{S}$ & 2 & 408 \\
\hline Crataegus mollis & $\mathrm{S}$ & 2 & 408 \\
\hline Crataegus lucorum & $S$ & 2 & 413 \\
\hline Agrimonia parviflora & $S$ & 2 & 442 \\
\hline Agrimonia pubescens & $S$ & 2 & 443 \\
\hline Trifolium dubium & $S$ & 2 & 455 \\
\hline Desmodium paniculatum & $S$ & 2 & 467 \\
\hline Lespedeza hirta & $\mathrm{S}$ & 2 & 470 \\
\hline Oxalis corniculata & $S$ & 2 & 503 \\
\hline Euonymus atropurpurea & $\mathrm{S}$ & 2 & 544 \\
\hline Althaea officinalis & $S$ & 2 & 573 \\
\hline Elaeagnus angustifolia & $\mathrm{S}$ & 2 & 605 \\
\hline Hydrocotyle umbellata & $S$ & 2 & 652 \\
\hline
\end{tabular}




\section{Appendix C:}

\section{Woody Plants In Missaukee County}

This is a list of presence classes for tree and shrub species in 98 stands of upland secondgrowth hardwoods in Missaukee County, Michigan (Elliott, 1953, pg. 275).

\begin{tabular}{|c|c|c|}
\hline Plant Name & Percent & Class \\
\hline \multicolumn{3}{|l|}{ Trees } \\
\hline Acer saccharum & 95 & 5 \\
\hline Fagus grandifolia & 86 & 5 \\
\hline Ulmus americana & 57 & 3 \\
\hline Tilia americana & 57 & 3 \\
\hline Fraxinus americana & 43 & 3 \\
\hline Ulmus thomasi & 35 & 2 \\
\hline Ulmus rubra & 33 & 2 \\
\hline Prunus serotina & 40 & 2 \\
\hline Acer rubrum & 30 & 2 \\
\hline Tsuga canadensis & 37 & 2 \\
\hline Betula lutea & 19 & 1 \\
\hline Betula papyrifera & 9 & 1 \\
\hline Quercus rubra var. borealis & 15 & 1 \\
\hline Quercus alba & 5 & 1 \\
\hline Pinus strobus & 5 & 1 \\
\hline Pinus resinosa & 3 & 1 \\
\hline Thuja occidentalis & 4 & 1 \\
\hline Fraxinus nigra & 1 & 1 \\
\hline Ostrya virginiana & 58 & 3 \\
\hline Prunus pensylvanica & 41 & 3 \\
\hline Populus grandidentata & 22 & 2 \\
\hline Populus tremuloides & 3 & 1 \\
\hline Amelanchier sp. & 8 & 1 \\
\hline Crataegus sp. & 1 & 1 \\
\hline \multicolumn{3}{|l|}{ Shrubs } \\
\hline Acer spicatum & 4 & 1 \\
\hline Corylus cornuta & 8 & 1 \\
\hline Cornus alternifolia & 12 & 1 \\
\hline Ribes cynosbati & 2 & 1 \\
\hline Rosa sp. & 1 & 1 \\
\hline Sainbucus pubens & 3 & 1 \\
\hline Viburnum acerifolium & 6 & 1 \\
\hline Spiraea sp. & 1 & 1 \\
\hline
\end{tabular}




\section{Appendix D:}

\section{Field Data Sheet Used to Record Cover-Class Numbers and Selected Shoot Counts for Understory Taxa}

COVER CLASS DATA SHEET FOR ANL/GRI ROW PROJECT, MIDLAND CD., MI

Page:

of Page(s). Serial Number:

Site: Date $(d / m / y)$ :

Transect Number: Quadrat Size: Number:

Data Collector(s):

(1) $=0-5 \%$ (2) $=5-25 \%$ (3) $=25-50 \%$ (4) $=50-75 \%$ (5) $=75-95 \%$ (6) $=95-100 \%$

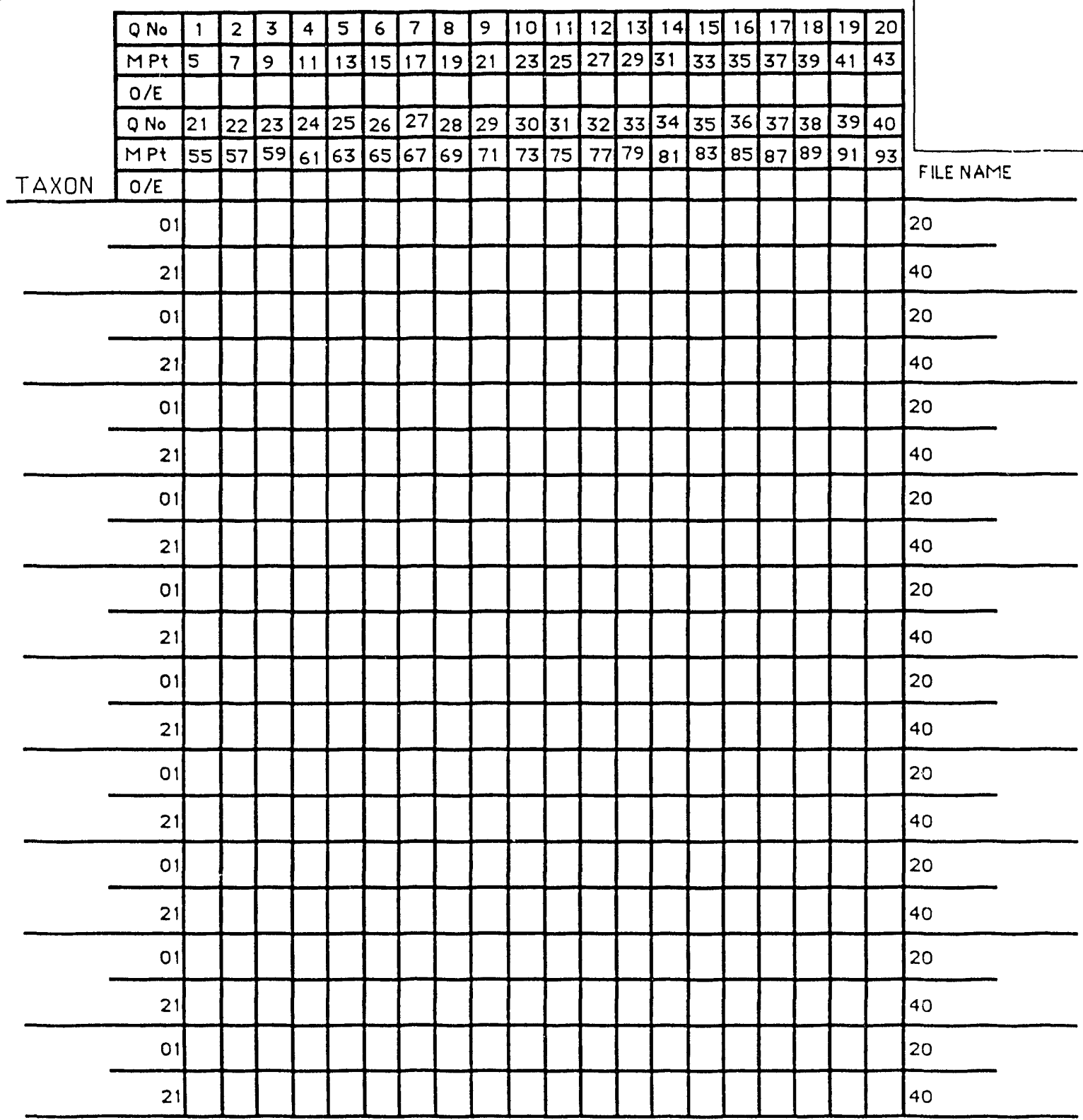




\section{Appendix E:}

\section{Field Data Sheet Used to Record Stem Diameters for Overstory Taxa}

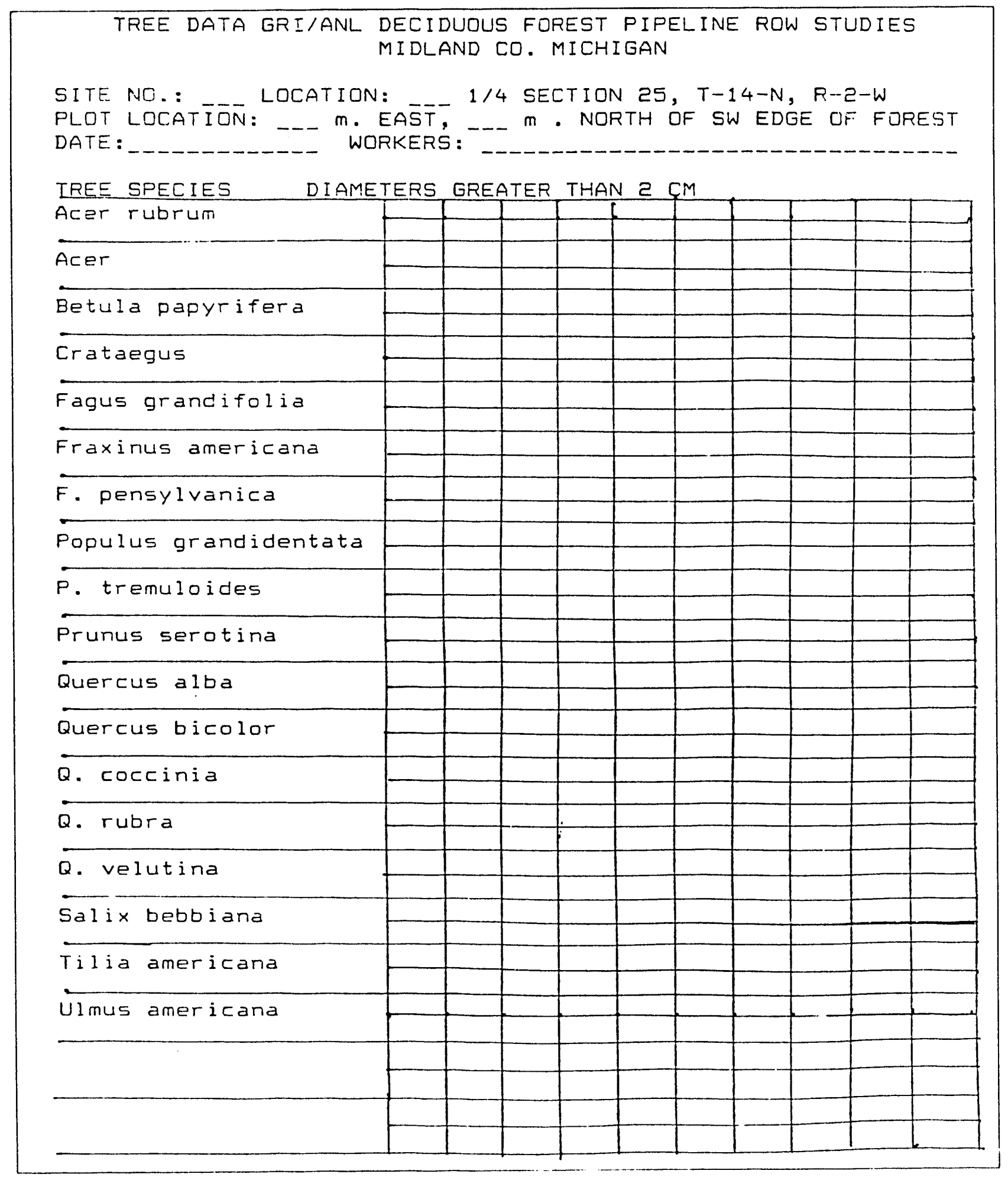




\section{Appendix F:}

Field Data Sheet Used to Map Overstory Taxa

TREE DATA GRI/ANL DECIDUOUS FOREST PIPELINE ROW STUDIES MIDLAND CO. MICHIGAN

SITE NO.: _.. LOCATION: _- $1 / 4$ SECTION 25, T-14-N, R-2-W

PLOT LOCATIŌN : _ $m$. EASTT, _. $m$. NORTH OF SW EDGE OF FOREST

DATE:

WORKERS:

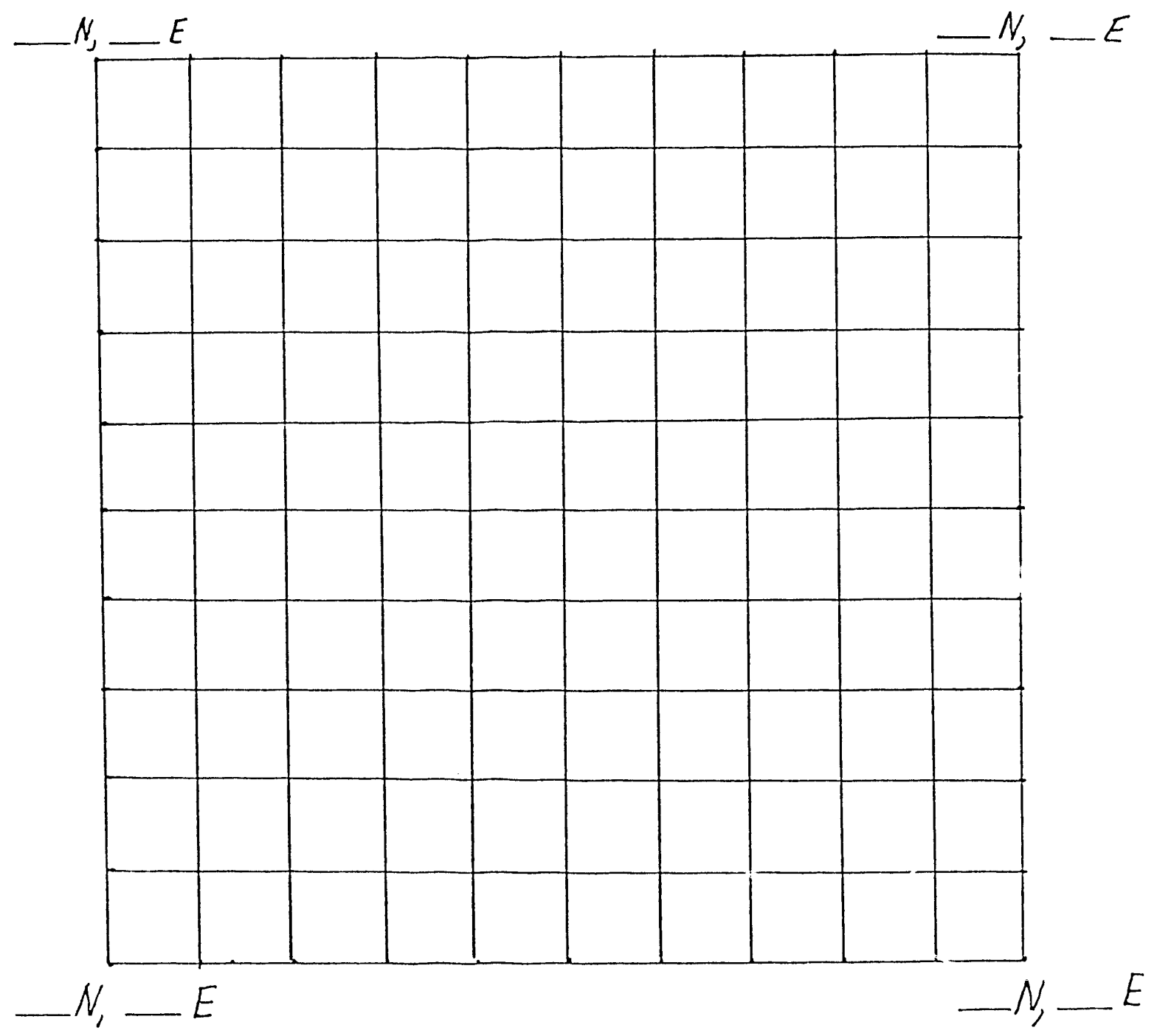




\section{Appendix G:}

Coordinates and Numbers for $10 \times 10$-Meter Plots Used to Analyze Overstory Taxa

\begin{tabular}{|c|c|c|c|c|c|}
\hline \multicolumn{3}{|c|}{ Site 1} & \multicolumn{3}{|c|}{ Site 2} \\
\hline $00 \mathrm{E}$ & $00 \mathrm{~N}$ & 1000 & OOE, & $00 \mathrm{~N}$ & 2000 \\
\hline $10 \mathrm{E}$ & $00 \mathrm{~N}$ & 1001 & $10 \mathrm{E}$ & $00 \mathrm{~N}$ & 2001 \\
\hline $20 \mathrm{E}$ & $00 \mathrm{~N}$ & 1002 & $20 \mathrm{E}$ & $00 \mathrm{~N}$ & 2002 \\
\hline $30 \mathrm{E}$ & $00 \mathrm{~N}$ & 1003 & $30 \mathrm{E}$ & $00 \mathrm{~N}$ & 2003 \\
\hline $40 \mathrm{E}$ & $00 \mathrm{~N}$ & 1004 & $40 \mathrm{E}$ & $00 \mathrm{~N}$ & 2004 \\
\hline $50 \mathrm{E}$ & $00 \mathrm{~N}$ & 1005 & $50 \mathrm{E}$ & $00 \mathrm{~N}$ & 2005 \\
\hline $60 \mathrm{E}$ & $00 \mathrm{~N}$ & 1006 & $60 \mathrm{E}$ & $00 \mathrm{~N}$ & 2006 \\
\hline $70 \mathrm{E}$ & $00 \mathrm{~N}$ & 1007 & $70 \mathrm{E}$ & $00 \mathrm{~N}$ & 2007 \\
\hline $80 \mathrm{E}$ & $00 \mathrm{~N}$ & 1008 & $80 \mathrm{E}$ & $00 \mathrm{~N}$ & 2008 \\
\hline $90 \mathrm{E}$ & $00 \mathrm{~N}$ & 1009 & $90 \mathrm{E}$ & $00 \mathrm{~N}$ & 2009 \\
\hline $00 \mathrm{E}$ & $10 \mathrm{~N}$ & 1100 & $00 \mathrm{E}$ & $10 \mathrm{~N}$ & 2100 \\
\hline $10 \mathrm{E}$ & $10 \mathrm{~N}$ & 1101 & $10 \mathrm{E}$ & $10 \mathrm{~N}$ & 2101 \\
\hline $20 \mathrm{E}$ & $10 \mathrm{~N}$ & 1102 & $20 \mathrm{E}$ & $10 \mathrm{~N}$ & 2102 \\
\hline $30 \mathrm{E}$ & $10 \mathrm{~N}$ & 1103 & $30 \mathrm{E}$ & $10 \mathrm{~N}$ & 2103 \\
\hline $40 \mathrm{E}$ & $10 \mathrm{~N}$ & 1104 & $40 \mathrm{E}$ & $10 \mathrm{~N}$ & 2104 \\
\hline $50 \mathrm{E}$ & $10 \mathrm{~N}$ & 1105 & $50 \mathrm{E}$ & $10 \mathrm{~N}$ & 2105 \\
\hline $60 \mathrm{E}$ & $10 \mathrm{~N}$ & 1106 & $60 \mathrm{E}$ & $10 \mathrm{~N}$ & 2106 \\
\hline $70 \mathrm{E}$ & $10 \mathrm{~N}$ & 1107 & $70 \mathrm{E}$ & $10 \mathrm{~N}$ & 2107 \\
\hline $80 \mathrm{E}$ & $10 \mathrm{~N}$ & 1108 & $80 \mathrm{E}$ & $10 \mathrm{~N}$ & 2108 \\
\hline $90 \mathrm{E}$ & $10 \mathrm{~N}$ & 1109 & $90 \mathrm{E}$ & $10 \mathrm{~N}$ & 2109 \\
\hline OOE, & $40 \mathrm{~N}$ & 1400 & O0E, & $40 \mathrm{~N}$ & 2400 \\
\hline $10 \mathrm{E}$ & $40 \mathrm{~N}$ & 1401 & $10 \mathrm{E}$ & $40 \mathrm{~N}$ & 2401 \\
\hline $20 \mathrm{E}$ & $40 \mathrm{~N}$ & 1402 & $20 \mathrm{E}$ & $40 \mathrm{~N}$ & 2402 \\
\hline $30 \mathrm{E}$ & $40 \mathrm{~N}$ & 1403 & $30 \mathrm{E}$ & $40 N$ & 2403 \\
\hline $40 \mathrm{E}$ & $40 \mathrm{~N}$ & 1404 & $40 \mathrm{E}$ & $40 \mathrm{~N}$ & 2404 \\
\hline $50 \mathrm{E}$ & $40 \mathrm{~N}$ & 1405 & $50 \mathrm{E}$ & $40 \mathrm{~N}$ & 2405 \\
\hline $60 \mathrm{E}$ & $40 \mathrm{~N}$ & 1406 & $60 \mathrm{E}$ & $40 \mathrm{~N}$ & 2406 \\
\hline $70 \mathrm{E}$ & $40 \mathrm{~N}$ & 1407 & $70 \mathrm{E}$ & $40 \mathrm{~N}$ & 2407 \\
\hline $80 \mathrm{E}$ & $40 \mathrm{~N}$ & 1408 & $80 \mathrm{E}$ & $40 \mathrm{~N}$ & 2408 \\
\hline $90 \mathrm{E}$ & $40 \mathrm{~N}$ & 1409 & $90 \mathrm{E}$ & $40 N$ & 2409 \\
\hline
\end{tabular}




\section{Appendix H:}

\section{Taxon Data Sheet Used to Keep Records on Voucher Specimens}

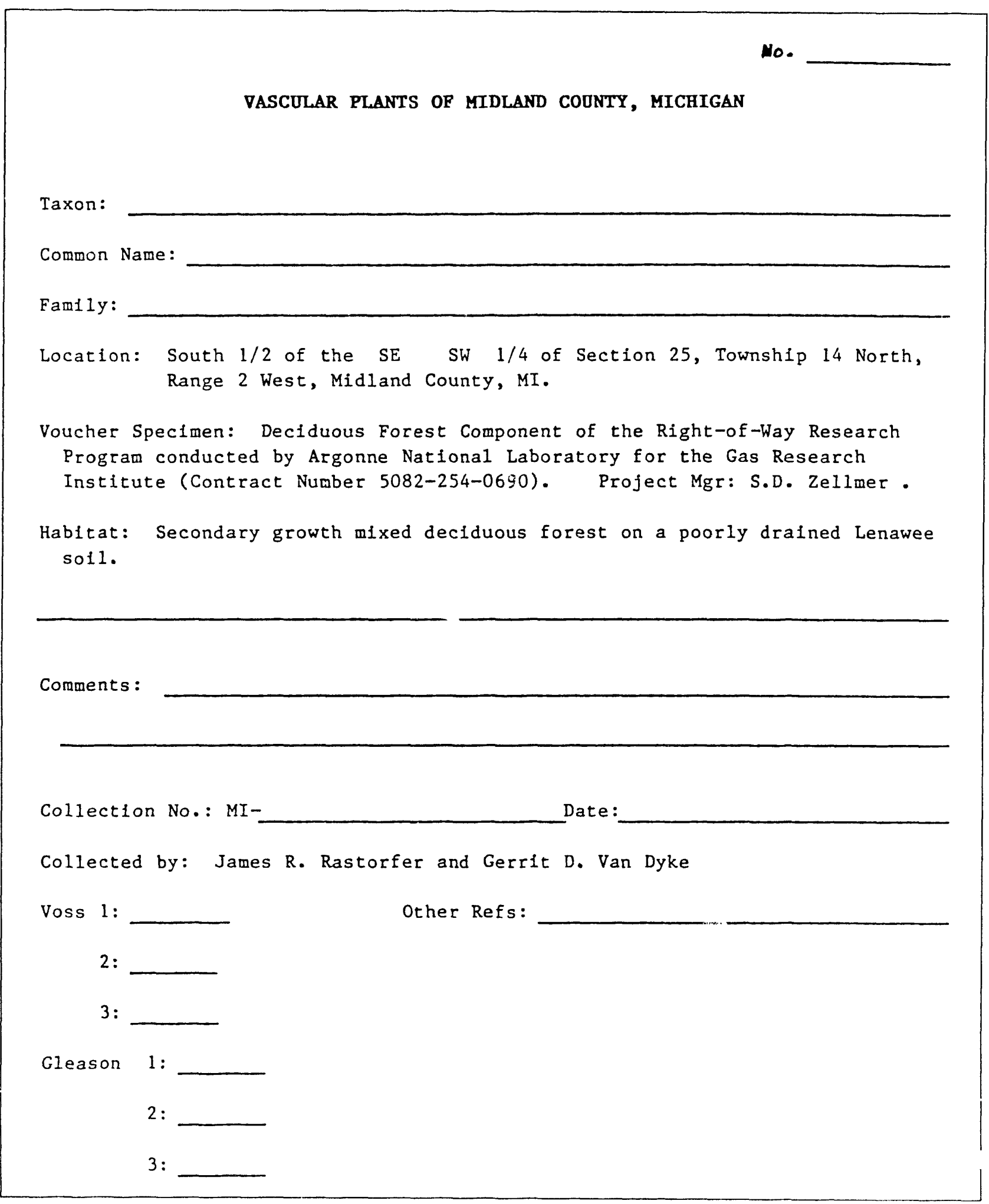




\section{Appendix I:}

\section{Vascular Plants in Midland County}

\begin{tabular}{|c|c|c|c|}
\hline $\begin{array}{l}\text { Plant } \\
\text { Type }\end{array}$ & Family & Species & $\begin{array}{l}\text { Where } \\
\text { Found }\end{array}$ \\
\hline Shr & Taxaceae & Taxus canadensis & W \\
\hline Tre & Pinaceae & Larix laricina & W \\
\hline Tre & Pinaceae & Pinus strobus & W \\
\hline Tre & Pinaceae & Pinus resinosa & \\
\hline Tre & Pinaceae & Pinus banksiana & $\mathrm{D}$ \\
\hline Tre & Pinaceae & Tsuga canadensis & $\mathrm{D}$ \\
\hline Tre & Cupressaceae & Thuja occidentalis & W \\
\hline $\mathrm{Hmc}$ & Typhaceae & Typha angustifolia & \\
\hline $\mathrm{Hmc}$ & Typhaceae & Typha latifolia & \\
\hline $\mathrm{Hmc}$ & Sparganiaceae & Sparganium elurycarpum & \\
\hline $\mathrm{Hmc}$ & Potamogetonaceae & Potamogeton pectinatus & \\
\hline $\mathrm{Hmc}$ & Potamogetonaceae & Potamogeton filiformis .. & \\
\hline $\mathrm{Hmc}$ & Potamogetonaceae & Potamogeton richardsonii & \\
\hline $\mathrm{Hmc}$ & Potamogetonaceae & Potamogeton nodosus & \\
\hline $\mathrm{Hmc}$ & Potamogetonaceae & Potamogeton illinoensis & \\
\hline $\mathrm{Hmc}$ & Potamogetonaceae & Potamogeton zosteriformis & \\
\hline $\mathrm{Hmc}$ & Potamogetonaceae & Potamogeton foliosus & \\
\hline $\mathrm{Hmc}$ & Najadaceae & Najas flexilis & \\
\hline $\mathrm{Hmc}$ & Alismataceae & Sagittaria latifolia & \\
\hline Hmc & Alismataceae & Alisma plantago-aquatica & \\
\hline $\mathrm{Hmc}$ & Hydrocharitaceae & Vallisneria americana & \\
\hline Gra & Poaceae & Schizachne purpurascens & $\mathrm{D}$ \\
\hline Gra & Poaceae & Eragrostis hypnoides & \\
\hline Gra & Poaceae & Eragrostis spectabilis & \\
\hline Gra & Poaceae & Eragrostis pectinacea & \\
\hline Gra & Poaceae & Poa saltuensis & $\mathrm{D}$ \\
\hline Gra & Poaceae & Poa alsodes & $\mathrm{D}$ \\
\hline Gra & Poaceae & Poa compressa & \\
\hline Gra & Poaceae & Poa pratensis & \\
\hline Gra & Poaceae & Poa palustris & W \\
\hline Gra & Poaceae & Bromus tectorum & \\
\hline Gra & Poaceae & Bromus latiglumis & $\mathrm{D}$ \\
\hline Gra & Poaceae & Bromus pubescens & $\mathrm{D}$ \\
\hline Gra & Poaceae & Festuca uhtusa & D \\
\hline Gra & Poaceae & Festuca ovina & $\mathrm{D}$ \\
\hline Gra & Poaceae & Glyceria septentrionalis & W \\
\hline Gra & Poaceae & Glyceria grandis & \\
\hline
\end{tabular}


Plant

Family

Species

Where

Type ${ }^{a}$

(

Found ${ }^{b}$

\begin{tabular}{|c|c|c|c|}
\hline Gra & Poaceae & Glyceria striata & W \\
\hline Gra & Poaceae & Triticum aestivum & \\
\hline Gra & Poaceae & Elymus canadensis & $\mathrm{D}$ \\
\hline Gra & Poaceae & Elymus virginicus & W \\
\hline Gra & Poaceae & Elymus villosus & W \\
\hline Gra & Poaceae & Hystrix patula & W \\
\hline Gra & Poaceae & Hordeum jubatum & \\
\hline Gra & Poaceae & Agropyron trachycaulum & W \\
\hline Gra & Poaceae & Agropyron repens & \\
\hline Gra & Poaceae & Sphenopholis intermedia & $\mathrm{D}$ \\
\hline Gra & Poaceae & Danthonia spicata & \\
\hline Gra & Poaceae & Brachyelytrum erectum & W \\
\hline Gra & Poaceae & Oryzopsis asperifolia & $\mathrm{D}$ \\
\hline $\mathrm{Gr}$ & Poaceae & Muhlenbergia mexicana & $\mathrm{D}$ \\
\hline Gra & Poaceae & Phleum pratense & \\
\hline Gra & Poaceae & Alopecurus aequalis & \\
\hline Cira & Poaceae & Milium effusum & $\mathrm{D}$ \\
\hline Gra & Poaceae & Sporobolus cryptandrus & \\
\hline Gra & Poaceae & Calamagrostis canadensis & \\
\hline Gra & Poaceae & Cinna latifolia & W \\
\hline Gra & Poaceae & Agrostis gigantea & W \\
\hline Gra & Poaceae & Agrostis stolonifera & \\
\hline Gra & Poaceae & Spartina pectinata & \\
\hline Gra & Poaceae & Phalaris arundinacea & \\
\hline Gra & Poaceae & Leersia virginica & \\
\hline Gra & Poaceae & Leersia oryzoides & \\
\hline Gra & Poaceae & Cenchrus longispinus & \\
\hline Gra & Poaceae & Echinochloa muricata & \\
\hline Gra & Poaceae & Digitaria sanguinalis & \\
\hline Gra & Poaceae & Panicum capillare & \\
\hline Gra & Poaceae & Panicum latifolium & $\mathrm{D}$ \\
\hline Gra & Poaceae & Panicum xanthophysum & \\
\hline Gra & Poaceae & Panicum depauperatum & \\
\hline Gra & Poaceae & Panicum linearifolium & \\
\hline Gra & Poaceae & Panicum boreale & \\
\hline Gra & Poaceae & Panicum columbianum & $\mathrm{D}$ \\
\hline Gra & Poaceae & Panicum praecocius & \\
\hline Gra & Poaceae & Panicum implicatum & \\
\hline Cyp & Cyperaceae & Carex cephaloidea & $\mathrm{D}$ \\
\hline Cyp & Cyperaceae & Carex sparganioides & $\mathrm{D}$ \\
\hline
\end{tabular}


Plant

Type $^{\mathrm{a}}$

Family

Species

Where

Found ${ }^{b}$

\begin{tabular}{|c|c|c|c|}
\hline Cyp & Cyperaceae & Carex rosea & D \\
\hline C.yp & Cyperaceae & Carex convoluta & D \\
\hline Cyp & Cyperaceae & Carex muhlenbergii & \\
\hline Cyp & Cyperaceae & Carex annectens & \\
\hline Cyp & Cyperaceae & Carex vulpinoidea & \\
\hline Cyp & Cyperaceae & Carex diandra & \\
\hline Cyp & Cyperaceae & Carex alopecoidea & D \\
\hline Cyp & Cyperaceae & Carex stipata & $\mathrm{D}$ \\
\hline Cyp & Cyperaceae & Carex trisperma & \\
\hline Сур & Cyperaceae & Carex disperma & \\
\hline Cyp & Cyperaceae & Carex brunnescens & W \\
\hline Cyp & Cyperaceae & Carex canescens & \\
\hline Cyp & Cyperaceae & Carex seorsa & W \\
\hline Cyp & Cyperaceae & Carex interior & \\
\hline Cyp & Cyperaceae & Carex atlantica & \\
\hline Cyp & Cyperaceae & Carex bromoides & W \\
\hline Cyp & Cyperaceae & Carex deweyana & $\mathrm{D}$ \\
\hline Cyp & Cyperaceae & Carex atinea & \\
\hline Cyp & Cyperaceae & Carex muskingumensis & W \\
\hline Cyp & Cyperaceae & Carex cumulata & \\
\hline Cyp & Cyperaceae & Carex brevior & \\
\hline Cyp & Cyperaceae & Carex bebbii & $\mathrm{D}$ \\
\hline Cyp & Cyperaceae & Carex cristatella & W \\
\hline Cyp & Cyperaceae & Carex projecta & W \\
\hline Cyp & Cyperaceae & Carex tribuloides & W \\
\hline Cyp & Cyperaceae & Carex scoparia & \\
\hline Cyp & Cyperaceae & Carex normalis & $\mathrm{D}$ \\
\hline Cyp & Cyperaceae & Carex tenera & $\mathrm{D}$ \\
\hline Cyp & Cyperaceae & Carex leptalea & $\mathrm{D}$ \\
\hline Cyp & Cyperaceae & Carex rugosperma & \\
\hline Cyp & Cyperaceae & Carex communis & $\mathrm{D}$ \\
\hline Cyp & Cyperaceae & Carex lucorum & \\
\hline Cyp & Cyperaceae & Carex pensylvanica & $\mathrm{D}$ \\
\hline Cyp & Cyperaceae & Carex peckii & $\mathrm{D}$ \\
\hline Cyp & Cyperaceae & Carex emmonsii & \\
\hline Cyp & Cyperaceae & Carex pedunculata & $\mathrm{D}$ \\
\hline Cyp & Cyperaceae & Carex hirtifolia & $\mathrm{D}$ \\
\hline Cyp & Cyperaceae & Carex aurea & $\mathrm{D}$ \\
\hline$C_{y p}$ & Cyperaceae & Carex woodii & $D$ \\
\hline Cyp & Cyperaceae & Carex tetanica & $\mathrm{D}$ \\
\hline
\end{tabular}


Plant

Type $^{\mathrm{a}}$

Family

Species

Where

Found ${ }^{b}$

\begin{tabular}{|c|c|c|c|}
\hline Cyp & Cyperaceae & Carex plantaginea & $\mathrm{D}$ \\
\hline Cyp & Cyperaceae & Carex careyana & D \\
\hline Cyp & Cyperaceae & Carex albursina & $\mathrm{D}$ \\
\hline Cyp & Cyperaceae & Carex laxiculmis & $\mathrm{D}$ \\
\hline Cyp & Cyperaceae & Carex digitalis & D \\
\hline Cyp & Cyperaceae & Carex leptonervia & $\mathrm{D}$ \\
\hline Cyp & Cyperaceae & Carex laxiflora & D \\
\hline Cyp & Cyperaceae & Carex blanda & $\mathrm{D}$ \\
\hline Cyp & Cyperaceae & Carex granularis & W \\
\hline Cyp & Cyperaceae & Carex hitchcockiana & $\mathrm{D}$ \\
\hline Cyp & Cyperaceae & Carex amphibola & W \\
\hline Cyp & Cyperaceae & Carex prasina & $\mathrm{D}$ \\
\hline Cyp & Cyperaceae & Carex gracillima & W \\
\hline Cyp & Cyperaceae & Carex arctata & $\mathrm{D}$ \\
\hline Cyp & Cyperaceae & Carex debilis & D \\
\hline Cyp & Cyperaceae & Carex sprengelii & $\mathrm{D}$ \\
\hline Cyp & Cyperaceae & Carex lanuginosa & \\
\hline Cyp & Cyperaceae & Carex scabrata & W \\
\hline Cyp & Cyperaceae & Carex paupercula & \\
\hline Cyp & Cyperaceae & Carex haydenii & \\
\hline Cyp & Cyperaceae & Carex emoryi & \\
\hline Cyp & Cyperaceae & Carex stricta & \\
\hline Cyp & Cyperaceae & Carex crinita & W \\
\hline Cyp & Cyperaceae & Carex folliculata & W \\
\hline Cyp & Cyperaceae & Carex comosa & \\
\hline Cyp & Cyperaceae & Carex pseudo-cyperus & \\
\hline Cyp & Cyperaceae & Carex hystericina & \\
\hline Сур & Cyperaceae & Carex tuckermanii & W \\
\hline Cyp & Cyperaceae & Carex retrorsa & W \\
\hline Cyp & Cyperaceae & Carex rostrata & \\
\hline Cyp & Cyperaceae & Carex grayi & D \\
\hline Cyp & Cyperaceae & Carex intumescens & W \\
\hline Cyp & Cyperaceae & Carex lupulina & W \\
\hline Cyp & Cyperaceae & Cyperus rivularis & \\
\hline Cyp & Cyperaceae & Cyperus aristatus & \\
\hline Cyp & Cyperaceae & Cyperus houghtonii & \\
\hline Cyp & Cyperaceae & Cyperus filiculmis & \\
\hline Cyp & Cyperaceae & Cyperus strigosus & \\
\hline$C_{y p}$ & Cypcraceae & Cyperus esculentus & \\
\hline Cyp & Cyperaceae & Eleocharis acicularis & \\
\hline
\end{tabular}


Plant

Typea

Family

Species

Where

Found $^{\mathrm{b}}$

\begin{tabular}{|c|c|c|c|}
\hline Cyp & Cyperaceae & Eleocharis erythropoda & \\
\hline Cyp & Cyperaceae & Scirpus validus & \\
\hline Cyp & Cyperaceae & Scirpus paludosus & \\
\hline Cyp & Cyperaceae & Scirpus atrovirens & W \\
\hline Cyp & Cyperaceae & Scirpus cyperinus & W \\
\hline $\mathrm{Hmc}$ & Araceae & Arisaema triphyllum & W \\
\hline $\mathrm{Hmc}$ & Araceae & Arisaema dracontium & $\mathrm{D}$ \\
\hline $\mathrm{Hmc}$ & Araceae & Acorus calamus & \\
\hline $\mathrm{Hmc}$ & Araceae & Peltandra virginica & \\
\hline $\mathrm{Hmc}$ & Lemnaceae & Spirodela polyrhiza & \\
\hline $\mathrm{Hmc}$ & Pontederiaceae & Heteranthera dubia & \\
\hline $\mathrm{Hmc}$ & Juncaceae & Luzula multiflora & W \\
\hline $\mathrm{Hmc}$ & Juncaceae & Luzula acuminata & $\mathrm{D}$ \\
\hline $\mathrm{Hmc}$ & Juncaceae & Juncus effusus & \\
\hline $\mathrm{Hmc}$ & Juncaceae & Juncus marginatus & \\
\hline $\mathrm{Hmc}$ & Juncaceae & Juncus bufonius & \\
\hline $\mathrm{Hmc}$ & Juncaceae & Juncus tenuis & \\
\hline $\mathrm{Hmc}$ & Juncaceae & Juncus dudleyi & \\
\hline $\mathrm{Hmc}$ & Juncaceae & Juncus canadensis & \\
\hline $\mathrm{Hmc}$ & Juncaceae & Juncus brachycephalus & \\
\hline $\mathrm{Hmc}$ & Juncaceae & Juncus torreyi & \\
\hline Hmc & Juncaceae & Juncus nodosus & \\
\hline Hmc & Juncaceae & Juncus articulatus & \\
\hline Hmc & Liliaceae & Asparagus officinalis & \\
\hline $\mathrm{Hmc}$ & Liliaceae & Smilax tamnoides & $\mathrm{D}$ \\
\hline $\mathrm{Hmc}$ & Liliaceae & Smilax illinoensis & $\mathrm{D}$ \\
\hline $\mathrm{Hmc}$ & Liliaceae & Polygonatum biflorum & W \\
\hline Hmc & Liliaceae & Polygonatum pubescens & D \\
\hline $\mathrm{Hmc}$ & Liliaceae & Streptopus roseus & $\mathrm{D}$ \\
\hline $\mathrm{Hmc}$ & Liliaceae & Trillium grandiflorum & W \\
\hline $\mathrm{Hmc}$ & Liliaceae & Tri'lium cernuum & $\mathrm{D}$ \\
\hline Hmc & Liliaceae & Me teola virginiana & W \\
\hline $\mathrm{Hmc}$ & Liliaceae & Erythronium americanum & $\mathrm{D}$ \\
\hline $\mathrm{Hmc}$ & Liliaceae & Erythronium albidum & $\mathrm{D}$ \\
\hline $\mathrm{Hmc}$ & Liliaceae & Lilium michiganense & W \\
\hline $\mathrm{Hmc}$ & Liliaceae & Hemerocallis fulva & \\
\hline $\mathrm{Hmc}$ & Liliaceae & Clintonia borealis & $\mathrm{D}$ \\
\hline $\mathrm{Hmc}$ & Liliaceae & Allium tricoccum & $\mathrm{D}$ \\
\hline $\mathrm{Hmc}$ & Liliaceae & Allium canadense & $\mathrm{D}$ \\
\hline İ̈mc & Liliaceae & Uvvuiaria sessiliifolia & $\mathrm{D}$ \\
\hline
\end{tabular}


Plant

Type ${ }^{a}$

Family

Species

Where

\begin{tabular}{|c|c|c|c|}
\hline Hmc & Liliaceae & Uvularia grandiflora & $\mathrm{D}$ \\
\hline Hmc & Liliaceae & Maianthemum canadense & W \\
\hline Hmc & Liliaceae & Smilacina racemosa & $\mathrm{D}$ \\
\hline Hmc & Liliaceae & Smilacina trifolia & \\
\hline $\mathrm{Hmc}$ & Liliaceae & Smilacina stellata & W \\
\hline Hmc & Dioscoreaceae & Dioscorea villosa & $\mathrm{D}$ \\
\hline $\mathrm{Hmc}$ & Amaryllidaceae & Hypoxis hirsuta & D \\
\hline Hmc & Iridaceae & Sisyrinchium angustifolium & D \\
\hline $\mathrm{Hmc}$ & Iridaceae & Sisyrinchium atlanticum & \\
\hline $\mathrm{Hmc}$ & Iridaceae & Sisyrinchium mucronatum & \\
\hline $\mathrm{Hmc}$ & Iridaceae & Sisyrinchium montanum & \\
\hline $\mathrm{Hmc}$ & Iridaceae & Iris virginica & W \\
\hline $\mathrm{Hmc}$ & Orchidaceae & Cypripedium acaule & \\
\hline Hmc & Orchidaceae & Cypripeduim calceolus & D \\
\hline Hmc & Orchidaceae & Cypripedium arietinum & \\
\hline $\mathrm{Hmc}$ & Orchidaceae & Habenaria psycodes & W \\
\hline $\mathrm{Hmc}$ & Orchidaceae & Habenaria lacera & \\
\hline $\mathrm{Hmc}$ & Orchidaceae & Habenaria hookeri & D \\
\hline $\mathrm{Hmc}$ & Orchidaceae & Corallorhiza trifida & $\mathrm{D}$ \\
\hline $\mathrm{Hmc}$ & Orchidaceae & Corallorhiza striata & $\mathrm{D}$ \\
\hline $\mathrm{Hmc}$ & Orchidaceae & Epipactis helleborine & $\mathrm{D}$ \\
\hline $\mathrm{Hmc}$ & Orchidaceae & Liparis loeselii & W \\
\hline $\mathrm{Hmc}$ & Orchidaceae & Malaxis unifolia & \\
\hline $\mathrm{Hmc}$ & Orchidaceae & Goodyera pubescens & $\mathrm{D}$ \\
\hline $\mathrm{Hmc}$ & Orchidaceae & Spiranthes romanzoffiana & \\
\hline Hmc & Orchidaceae & Spiranthes cernua & \\
\hline Hdc & Saururaceae & Saururus cernuus & W \\
\hline Tre & Salicaceae & Salix exigua & \\
\hline Tre & Salicaceae & Salix nigra & \\
\hline Tre & Salicaceae & Salix eriocephala & \\
\hline Shr & Salicaceae & Salix bebbiana & \\
\hline Shr & Salicaceae & Salix discolor & \\
\hline Tre & Salicaceae & Salix humilis & \\
\hline Tre & Salicaceae & Salix lucida & \\
\hline Tre & Salicaceae & Salix amygdaloides & \\
\hline Tre & Salicaceae & Salix pyrifolia & \\
\hline Tre & Salicaceae & Salix petiolaris & \\
\hline Tre & Salicaceae & Populus alba & $\mathrm{D}$ \\
\hline Tre & Salicaceae & Populus balsamifera & W \\
\hline Tre & Salicaceae & Populus deltoides & $\underline{w}$ \\
\hline
\end{tabular}


Plant

Family

Species

Where

Type ${ }^{a}$

Family

Found $^{b}$

\begin{tabular}{|c|c|c|c|}
\hline Tre & Salicaceae & Populus tremuloides & W \\
\hline Tre & Salicaceae & Populus grandidentat. & $\mathrm{D}$ \\
\hline Shr & Myricaceae & Comptonia peregrina & \\
\hline Shr & Myricaceae & Myrica gale & \\
\hline Tre & Juglandaceae & Juglans cinerea & W \\
\hline Tre & Juglandaceae & Carya cordiformis & D \\
\hline Tre & Juglandaceae & Carya ovata & $\mathrm{D}$ \\
\hline Shr & Betulaceae & Alnus rugosa & \\
\hline Tre & Betulaceae & Betula alleghaniensis & \\
\hline Shr & Betulaceae & Betula pumila & \\
\hline Tre & Betulaceae & Betula papyrifera & $\mathrm{D}$ \\
\hline Shr & Betulaceae & Corylus cornuta & \\
\hline Tre & Betulaceae & Carpinus caroliniana & W \\
\hline Tre & Betulaceae & Ostrya virginiana & D \\
\hline Tre & Fagaceae & Quercus velutina & $\mathrm{D}$ \\
\hline Tre & Fagaceae & Quercus rubra & \\
\hline Tre & Fagaceae & Quercus coccinea & \\
\hline Tre & Fagaceae & Quercus alba & $\mathrm{D}$ \\
\hline Tre & Fagaceae & Quercus bicolor & W \\
\hline Tre & Fagaceae & Fagus grandifolia & $\mathrm{D}$ \\
\hline Tre & Ulmaceae & Ulmus rubra & $\mathrm{D}$ \\
\hline Tre & Ulmaceae & Ulmus americana & W \\
\hline Tre & Ulmaceae & Celtis occidentalis & $\mathrm{D}$ \\
\hline $\mathrm{Hdc}$ & Ulmaceae & Urtica dioica & $\mathrm{D}$ \\
\hline Hdc & Ulmaceae & Boehmeria cylindrica & W \\
\hline Hdc & Santalaceae & Comandra umbellata & \\
\hline Hdc & Aristolochiaceae & Asarum canadense & $\mathrm{D}$ \\
\hline Hdc & Polygonaceae & Rumex acetosella & \\
\hline $\mathrm{Hdc}$ & Polygonaceae & Rumex obtusifolius & \\
\hline Hdc & Polygonaceae & Rumex altissimus & \\
\hline Hdc & Polygonaceae & Rumex verticillatus & W \\
\hline Hdc & Polygonaceae & Rumex crispus & \\
\hline $\mathrm{Hdc}$ & Polygonaceae & Fagopyrum esculentum & \\
\hline Hdc & Polygonaceae & Polygonum virginianum & W \\
\hline $\mathrm{Hdc}$ & Polygonaceae & Polygonum cilinode & \\
\hline Hdc & Polygonaceae & Polygonum convolvulus & \\
\hline Hdc & Polygonaceae & Polygonum scandens & $\mathrm{D}$ \\
\hline Hdc & Polygonaceae & Polygonum amphibium & \\
\hline Hdc & Polygonaceae & Polygonum pensylvanicum & \\
\hline $\mathrm{Hdc}$ & Polygonaceae & Polygonum lapathifolium & \\
\hline
\end{tabular}


Plant

Type ${ }^{\mathrm{a}}$

Family

Species

Where

Found $^{\mathrm{b}}$

$\begin{array}{ll}\text { Hdc } & \text { Chenopodiaceae } \\ \text { Hdc } & \text { Chenopodiaceae } \\ \text { Hdc } & \text { Chenopodiaceae } \\ \text { Hdc } & \text { Nyctaginaceae } \\ \text { Hdc } & \text { Portulacaceae } \\ \text { Hdc } & \text { Portulacaceae } \\ \text { Hdc } & \text { Caryophyllaceae } \\ \text { Hdc } & \text { Caryophyllaceae } \\ \text { Hdc } & \text { Caryophyllaceae } \\ \text { Hdc } & \text { Caryophyllaceae } \\ \text { Hdc } & \text { Caryophyllaceae } \\ \text { Hdc } & \text { Caryophyllaceae } \\ \text { Hdc } & \text { Caryophyllaceae } \\ \text { Hdc } & \text { Caryophyllaceae } \\ \text { Hdc } & \text { Caryophyllaceae } \\ \text { Hdc } & \text { Caryophyllaceae } \\ \text { Hdc } & \text { Caryophyllaceae } \\ \text { Hdc } & \text { Ranunculaceae } \\ \text { Hdc } & \text { Ranunculaceae } \\ \text { Hdc } & \text { Ranunculaceae } \\ \text { Hdc } & \text { Ranunculaceae } \\ \text { Hdc } & \text { Ranunculaceae } \\ \text { Hdc } & \text { Ranunculaceae } \\ \text { Hdc } & \text { Ranunculaceae } \\ \text { Hdc } & \text { Ranunculaceae } \\ \text { Hdc } & \text { Ranunculaceae } \\ \text { Hdc } & \text { Ranunculaceae } \\ \text { Hdc } & \text { Ranunculaceae } \\ \text { Hdc } & \text { Ranunculaceae } \\ \text { Hdc } & \text { Ranunculaceae } \\ \text { Hdc } & \text { Ranunculaceae } \\ \text { Hdc } & \text { Ranunculaceae } \\ \text { Hdc } & \text { Ranunculaceae } \\ \text { Hdc } & \text { Ranunculaceae } \\ \text { Hdc } & \text { Ranunculaceae } \\ \text { Hdc } & \text { Ranunculaceae } \\ \text { Hdc } & \text { Ranunculaceae } \\ \text { Hdc } & \text { Ranunculaceae } \\ & \text { Berberidaceae }\end{array}$

Salsola kali

Atriplex patula

Chenopodium hybridum

Mirabilis albida

Portulaca grandiflora

Claytonia virginica

D

Spergula arvensis

Stellaria media

D

Stellaria longifolia

W

Cerastium arvense

Cerastium fontanum

Arenaria serpyllifolia

Dianthus armeria

Saponaria officinalis

Silene antirrhina

Silene pratensis

Ceratophyllum demersum

Clematis virginiana

Aquilegia canadensis

D

Thalictrum dioicum

D

Thalictrum dasycarpum

Actaea rubra

Actaea pachypoda

Coptis trifolia

Hepatica americana

Hepatica acutiloba

Ranunculus longirostris

Ranunculus flabellaris

Ranunculus recurvatus

W

Ranunculus sceleratus

Ranunculus abortivus

D

Ranunculus pensylvanicus

Ranunculus acris

Ranunculus hispidus

W

Caltha palustris

W

Isopyrum biternatum

D

Anemone canadensis

Anemone quinquefolia W

Anemone virginiana

D

Berberis vulgaris

D 
Plant Type ${ }^{\mathrm{a}}$ Family

Species

Where

Found $b$

$\begin{array}{ll}\text { Hdc } & \text { Berberidaceae } \\ \text { Hdc } & \text { Berberidaceae } \\ \text { Vin } & \text { Menispermaceae } \\ \text { Tre } & \text { I raceae } \\ \text { Hdc } & \text { Papaveraceae } \\ \text { Hdc } & \text { Papaveraceae } \\ \text { Hdc } & \text { Fumariaceae } \\ \text { Hdc } & \text { Fumariaceae } \\ \text { Hdc } & \text { Brassicaceae } \\ \text { Hdc } & \text { Brassicaceae } \\ \text { Hdc } & \text { Brassicaceae } \\ \text { Hdc } & \text { Brassicaceae } \\ \text { Hdc } & \text { Brassicaceae } \\ \text { Hdc } & \text { Brassicaceae } \\ \text { Hdc } & \text { Brassicaceae } \\ \text { Hdc } & \text { Brossicaceae } \\ \text { Hdc } & \text { Brassicaceae } \\ \text { Hdc } & \text { Brassicaceae } \\ \text { Hdc } & \text { Brassicaceae } \\ \text { Hdc } & \text { Brassicaceae } \\ \text { Hdc } & \text { Brassicaceae } \\ \text { Hdc } & \text { Brassicaceae } \\ \text { Hdc } & \text { Brassicaceae } \\ \text { Hdc } & \text { Brassicaceae } \\ \text { Hdc } & \text { Brassicaceae } \\ \text { Hdc } & \text { Brassicaceae } \\ \text { Hdc } & \text { Brassicaceae } \\ \text { Hdc } & \text { Droseraceae } \\ \text { Hdc } & \text { Saxifragaceae } \\ \text { Hdc } & \text { Saxifragaceae } \\ \text { Hdc } & \text { Saxifragaceae } \\ \text { Brm } & \text { Grossulariaceae } \\ \text { Brm } & \text { Grossulariaceae } \\ \text { Brm } & \text { Grossulariaceae } \\ \text { Brm } & \text { Grossulariaceae } \\ \text { Brm } & \text { Grossulariaceae } \\ \text { Shr } & \text { Hamamelidaceae } \\ \text { Tre } & \text { Platanaceae } \\ \text { Brm } & \text { Rosaceae } \\ \text { Brm } & \text { Rosaceae } \\ & \end{array}$

Caulophyllum thalictroides

D

Podophyllum peltatum

D

Menispermum canadense

W

Sassafras albidum

W

Macleaya cordata

Sanguinaria canadensis

D

Dicentra cucullaria

D

Corydalis sempervirens

Barbarea vulgaris

Brassica kaber

D

Rorippa palustris

Sisymbrium altissimum

D

Camelina microcarpa

Erysimum cheiranthoides

Alyssum alyssoides

Dentaria laciniata

Dentaria diphylla

D

Armoracia rusticana

Cardamine douglassii

D

Cardamine bulbosa

D

Arabis glabra

D

Arabis hirsuta

Arabis caucasica

Arabis laevigata

D

Berteroa incana

D

Lepidium densiflorum

D

Lepidium virginicum

D

Drosera rotundifolia

Chrysosplenium americanum W

Mitella diphylla

Mitella nuda

D

Ribes cynosbati W

Ribes hirtellum D

Ribes americanum W

Ribes glandulosum D

Ribes triste W

Hamamelis virginiana D

Platanus occidentalis D

Rubus pubescens W

Rubus strigosus

D 
Plant

Family

Species

Where

Type ${ }^{a}$

Rubus hispidus

W

\begin{tabular}{ll} 
Brm & Rosaceae \\
Brm & Rosaceae \\
Brm & Rosaceae \\
Brm & Rosaceae \\
Brm & Rosaceae \\
Brm & Rosaceae \\
Tre & Rosaceae \\
Tre & Rosaceae \\
Shr & Rosaceae \\
Tre & Rosaceae \\
Shr & Rosaceae \\
Shr & Rosaceae \\
Shr & Rosaceae \\
Shr & Rosaceae \\
Shr & Rosaceae \\
Tre & Rosaceae \\
Shr & Rosaceae \\
Tre & Rosaceae \\
Tre & Rosaceae \\
Tre & Rosaceae \\
Tre & Rosaceae \\
Tre & Rosaceae \\
Tre & Rosaceae \\
Tre & Rosaceae \\
Tre & Rosaceae \\
Tre & Rosaceae \\
Hdc & Rosaceae \\
Shr & Rosaceae \\
Hdc & Rosaceae \\
Hdc & Rosaceae \\
Hdc & Rosaceae \\
Hdc & Rosaceae \\
Hdc & Rosaceae \\
Hdc & Rosaceae \\
Hdc & Rosaceae \\
Hdc & Rosaceae \\
Hdc & Rosaceae \\
Hdc & Rosaceae \\
Hdc & Rosaceae \\
Hdc & Fabaceae \\
& \\
\hline
\end{tabular}

Rubus allegheniensis

D

Rosa eglanteria

Rosa cinnamomea

Rosa palustris

Rosa blanda

Pruilus serotina

D

Prunus virginiana

D

Prunus pumila

Prunus pensylvanica

D

Prunus americana

D

Physocarpus opulifolius

Spiraea tomentosa

Spiraea alba

Aronia prunifolia

D

Amelanchier arborea W

Amelanchier interior

D

Crataegus calpodendron

D

Crataegus punctata

W

Crataegus brainerdii

D

Crataegus mollis

D

Crataegus coccinea

D

Crataegus lucorum

D

Crataegus flabellata

D

Malus pumila

D

Malus coronaria

D

Fragaria virginiana

D

Potentilla fruticosa

Potentilla palustris

Potentilla arguta

Potentilla norvegica D

Potentilla simplex D

Potentilla argentea D

Potentilla recta D

Geum canadense D

Geum laciniatum W

Geum aleppicum W

Agrimonia gryposepala D

Agrimonia pubescens D

Melilotus alba 
Plant Family

Species

Where Typea

Fabaceae

Fabaceae

$\mathrm{Hdc}$

$\mathrm{Hdc}$

$\mathrm{Hdc}$

Hdc

Hdc

Hdc

$\mathrm{Hdc}$

Hdc

Hdc

$\mathrm{Hdc}$

$\mathrm{Hdc}$

Hdc

Tre

$\mathrm{Hdc}$

Hdc

$\mathrm{Hdc}$

$\mathrm{Hdc}$

$\mathrm{Hdc}$

$\mathrm{Hdc}$

Hdc

$\mathrm{Hdc}$

$\mathrm{Hdc}$

$\mathrm{Hdc}$

$\mathrm{Hdc}$

Shr

Vin

Shr

Shr

Shr

Shr

Vin

Vin

Vin

Shr

Tre

Tre

Tre

Shr

Vin
Fabaceae

Fabaceae

Fabaceae

Fabaceae

Fabaceae

Fabaceae

Fabaceae

Fabaceae

Fabaceae

Fabaceae

Fabaceae

Fabaceae

Fabaceae

Fabaceae

Fabaceae

Linaceae

Oxalidaceae

Geraniaceae

Rutaceae

Polygalaceae

Polygalaceae

Polygalaceae

Polygalaceae

Anacardiaceae

Anacardiaceae

Anacardiaceae

Anacardiaceae

Aquifoliaceae

Aquifoliaceae

Celastraceae

Celastraceae

Celastraceae

Staphyleaceae

Aceraceae

Aceraceae

Hippocastanaceae

Rhamnaceae

Vitaceae
Melilotus officinalis

Trifolium pratense

Trifolium repens

Trifolium hybridum

Trifolium aureum

Trifolium campestre

Medicago lupulina

Amphicarpaea bracteata

Phaseolus vulgaris

Desmodium glutinosum

Desmodium canadense

Desmodium paniculatum

Lespedeza hirta

Robinia pseudoacacia

Vicia americana

Vicia villosa

Apios americana

Linum usitatissimum

Oxalis fontana

Geranium maculatum

Zanthoxylum americanum

Polygala paucifolia

Polygala verticillata

Polygala polygama

Polygala sanguinea

Toxicodendron vernix

Toxicodendron radicans

Rhus typhina

Rhus $x$ pulvinata

Nemopanthus mucronatus

Ilex verticillata

Celastrus scandens

Euonymus obovata

Euonymus atropurpurea D

Staphylea trifolia

Acer saccharum

Acer rubrum

Aesculus hippocastanum D

Rhamnus alnifolia D

Parthenocissus quinquefolia W
D

D

D

W

D

D

D

D

D

D

D

D

W

D

D

W

W

D

D

W

W

D

W

D

W

W 
Plant

Type ${ }^{a}$

Family

Species

Where

Found $b$

\begin{tabular}{|c|c|c|c|}
\hline Vin & Vitaceae & Vitis riparia & $\mathrm{D}$ \\
\hline Tre & Tiliaceae & Tilia americana & $\mathrm{D}$ \\
\hline Hdc & Clusiaceae & Triadenum fraseri & \\
\hline Shr & Clusiaceae & Hypericum prolificum & $\mathrm{D}$ \\
\hline Shr & Clusiaceae & Hypericum kalmianum & \\
\hline Hdc & Clusiaceae & Hypericum majus & \\
\hline Hdc & Cistaceae & Lechea intermedia & \\
\hline Hdc & Violaceae & Viola pubescens & $\mathrm{D}$ \\
\hline Hdc & Violaceae & Viola striata & $\mathrm{D}$ \\
\hline Hdc & Violaceae & Viola conspersa & $\mathrm{D}$ \\
\hline Hdc & Violaceae & Viola adunca & \\
\hline Hdc & Violaceae & Viola lanceolata & \\
\hline Hdc & Violaceae & Viola blanda & $\mathrm{D}$ \\
\hline Hdc & Violaceae & Viola sagittata & $\mathrm{D}$ \\
\hline Hdc & Violaceae & Viola affinis & W \\
\hline Hdc & Violaceae & Viola sororia & $\mathrm{D}$ \\
\hline Hdc & Lythraceae & Lythrum alatum & \\
\hline Tre & Nyssaceae & Nyssa sylvatica & $\mathrm{D}$ \\
\hline Hdc & Onagraceae & Circaea alpina & D \\
\hline Hdc & Onagraceae & Circaea lutetiana & $\mathrm{D}$ \\
\hline Hdc & Onagraceae & Ludwigia polycarpa & \\
\hline $\mathrm{Hdc}$ & Onagraceae & Epilobium angustifolium & D \\
\hline Hdc & Onagraceae & Epilobium leptophyllum & \\
\hline Hdc & Onagraceae & Epilobium ciliatum & $\mathrm{D}$ \\
\hline Hdc & Onagraceae & Oenothera perennis & \\
\hline Hdc & Onagraceae & Oenothera parviflora & $\mathrm{D}$ \\
\hline Hdc & Onagraceae & Oenothera biennis & \\
\hline Hdc & Haloragaceae & Myriophyllum heterophyllum & \\
\hline Hdc & Araliaceae & Panax trifolius & W \\
\hline Hdc & Araliaceae & Aralia racemosa & D \\
\hline Hdc & Araliaceae & Aralia nudicaulis & D \\
\hline $\mathrm{Hdc}$ & Araliaceae & Aralia hispida & \\
\hline Hdc & Araliaceae & Panax quinquefolius & \\
\hline Hdc & Apiaceae & Sanicula gregaria & $\mathrm{D}$ \\
\hline Hdc & Apiaceae & Sanicula marilandica & W \\
\hline Hdc & Apiaceae & Daucus carota & D \\
\hline Hdc & Apiaceae & Osmorhiza longistylis & W \\
\hline Hdc & Apiaceae & Osmorhiza claytonii & D \\
\hline Hdc & Apiaceae & Angelica atropurpurea & D \\
\hline Hdc & Apiaceae & Heracleum maximum & D \\
\hline Hdc & Apiaceae & Pastinaca sativa & D \\
\hline Hdc & Apiaceae & Erigenia bulbosa & $\mathrm{D}$ \\
\hline Hdc & Apiaceae & Cryptotaenia canadensis & W \\
\hline Hdc & Apiaceae & Zizia aurea & W \\
\hline
\end{tabular}


Plant

Type $^{\mathrm{a}}$

Family

Species

Where

Found ${ }^{b}$

Hdc

Apiaceae

Cicuta bulbifera

Htc Apiaceae

Cicuta maculata

Cornus canadensis

Shr Cornaceae

Shr Cornaceae

Shr Cornaceae

Shr Cornaceae

Cornus alternifolia

Cornus stolonifera

Shr Cornaceae

Cornus amomum

Cornus foemina

W

D

D

W

D

a $\mathrm{Brm}=$ brambles, Cyp $=$ sedges, Gra $=$ grasses, $\mathrm{Hdc}=$ herbaceous dicots, $\mathrm{Hmc}=$ herbaceous monocots, $\mathrm{Shr}=$ shrubs, Tre $=$ trees, and Vin $=$ vines.

bW = wet deciduous woods, $\mathrm{D}=$ deciduous woods.

Source: Voss $(1972,1985)$. 


\section{Appendix J:}

\section{Cover-Class Values and Frame Used in Cover Estimation Sampling ${ }^{\star}$}

TABLE J.1 Values for Cover Estin. ations

\begin{tabular}{ccc}
\hline $\begin{array}{c}\text { Cover } \\
\text { Class }\end{array}$ & $\begin{array}{c}\text { Range } \\
\text { of Cover } \\
(\%)\end{array}$ & $\begin{array}{c}\text { Midpoint of } \\
\text { Cover Class } \\
(\%)\end{array}$ \\
\hline & & \\
1 & $0-5$ & 2.5 \\
2 & $5-25$ & 15.0 \\
3 & $25-50$ & 37.5 \\
4 & $50-75$ & 62.5 \\
5 & $75-95$ & 85.0 \\
6 & $95-100$ & 97.5 \\
\hline
\end{tabular}

FIGURE J.1 Diagram of the $1 \times 1$-Meter Frame Used for Cover Estimation Sampling

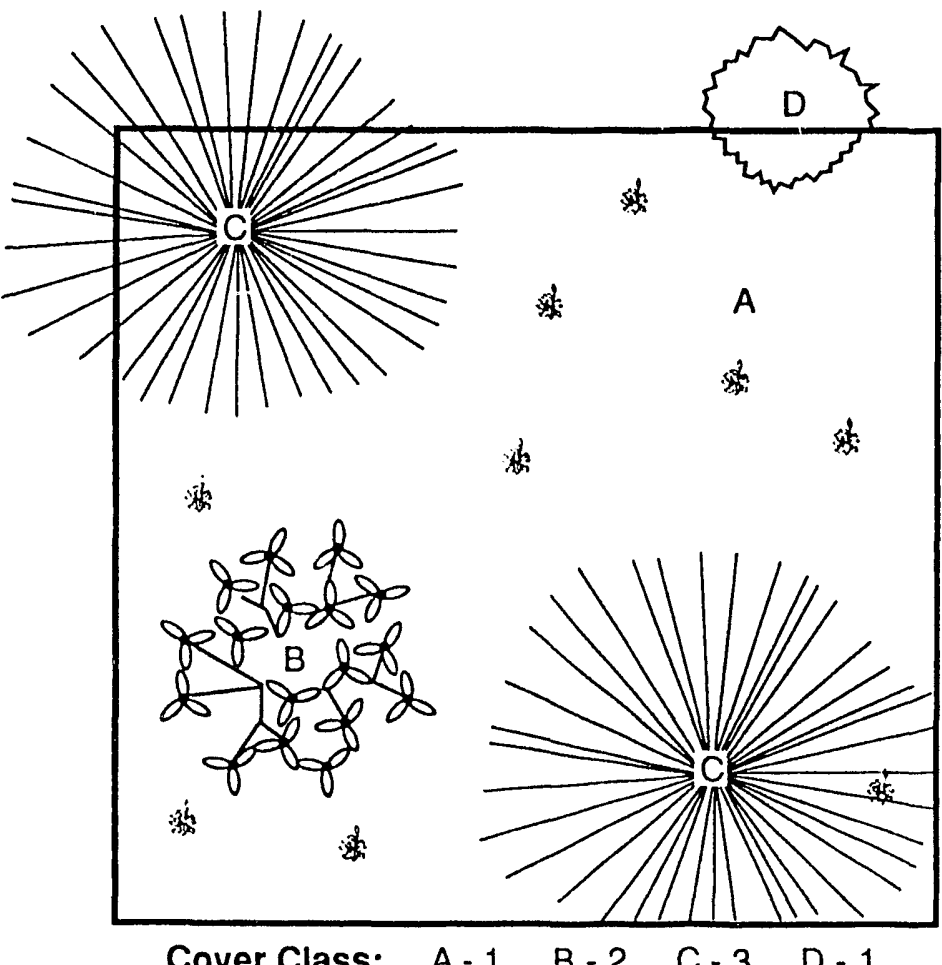

*Source: Adapted from Daubenmire (1968). 


\section{Appendix K:}

\section{Sample Data Collected and Calculated for Sensitive Fern}

Here is a sample of data (cover-class number per plot) collected in the field and average coverages and frequencies calculated for the species Onoclea sensibilis.

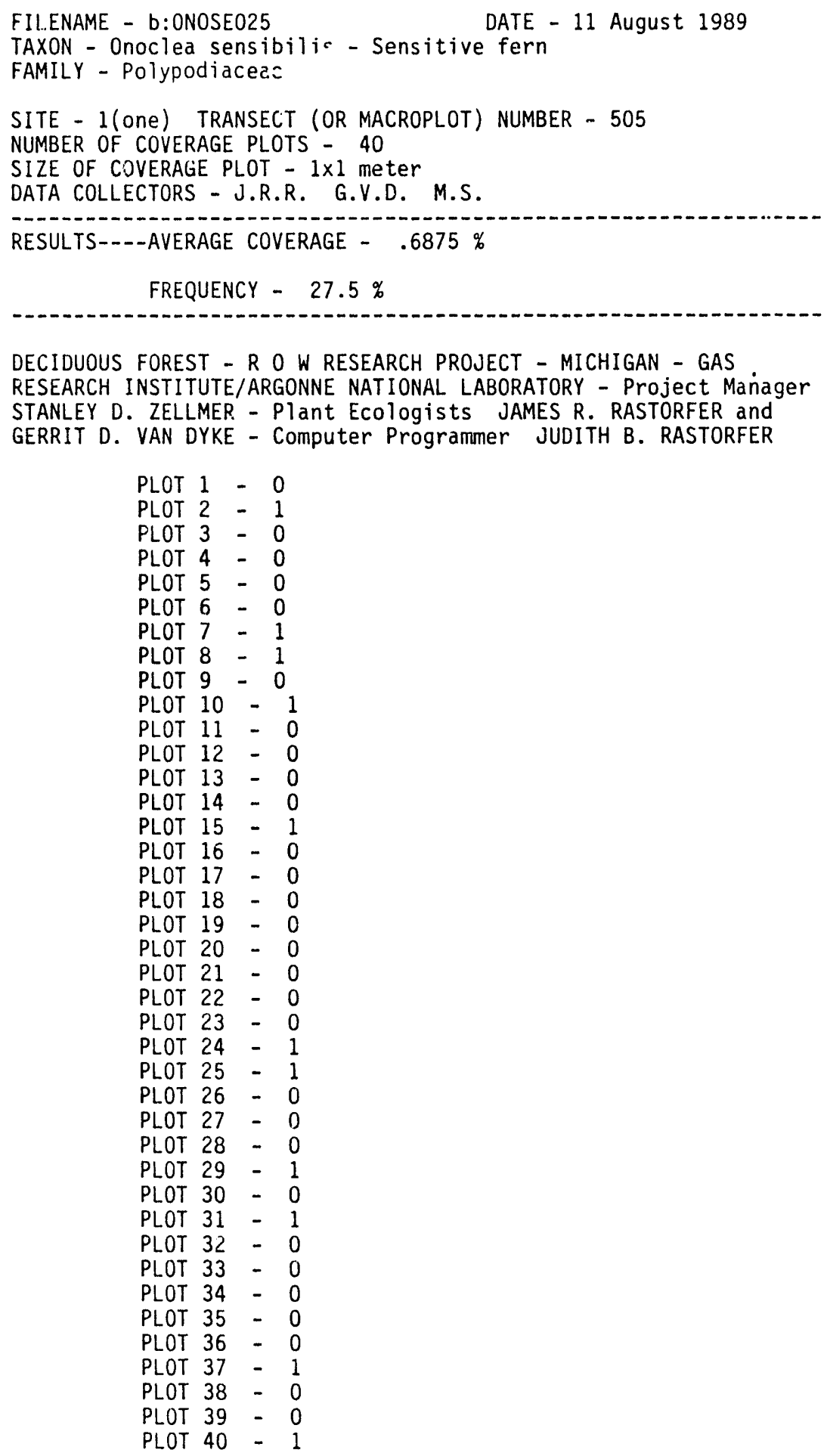


FILENAME - $b:$ ONOSE024

DATE - 11 August 1.389

TAXON - Onoclea sensibilis - Sensitive fern

FAMILY - Polypodiaceae

SITE - 1 (one) TRANSECT (OR MACROPLOT) NUMBER - 101

NUMBER OF COVERAGE PLOTS - 40

SIZE OF COVERAGE PLOT - $1 \times 1$ meter

DATA COLLECTORS - J.R.R. G.V.D. M.S.

RESULTS--.-AVERAGE COVERAGE - $3.5 \%$

FREQUENCY - $45 \%$

DECIDUOUS FOREST - R 0 W RESEARCH PROJECT - MICHIGAN - GAS RESEARCH INSTITUTE/ARGONNE NATIONAL LABORATORY - Project Manager STANLEY D. ZELLMER - Plant Ecologists JAMES R. RASTORFER and GERRIT D. VAN DYKE - Computer Programmer JUDITH B. RASTORFER

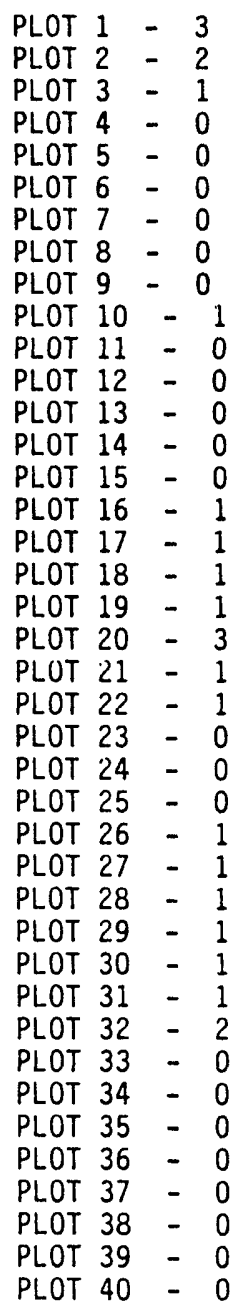




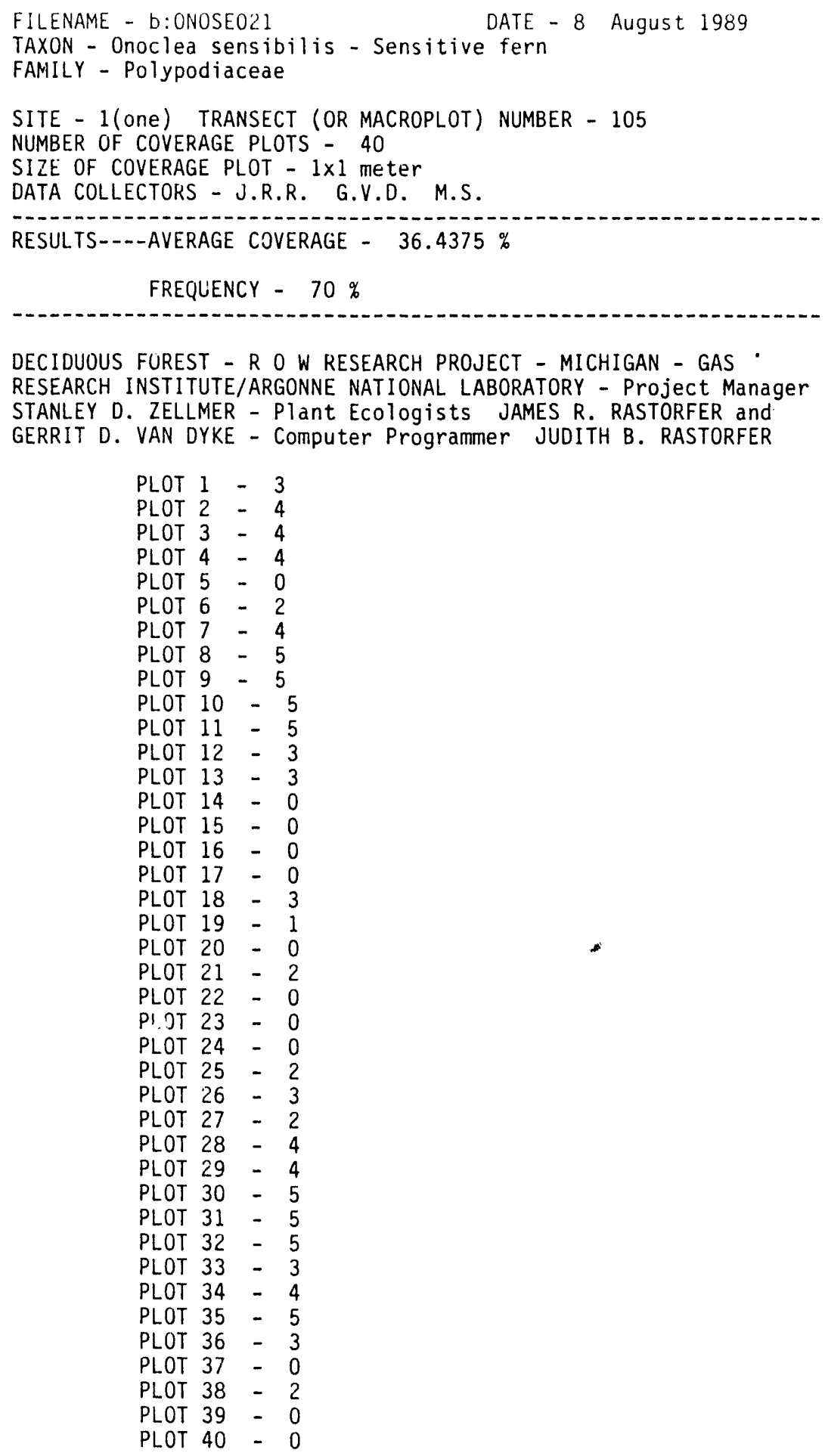


FILENAME - $b:$ ONOSE022

DATE - 9 August 1989

TAXON - Onoclea sensibilis - Sensitive fern

FAMILY - Polypodiaceae

SITE - 1(ONe) TRANSECT (OR MACROPLOT) NUMBER - 113

NUMBER OF COVERAGE PLOTS - 40

SIZE OF COVERAGE PLOT - $1 \times 1$ meter

DATA COLLECTORS - J.R.R. G.V.D. M.S.

RESULTS-.-AVERAGE COVERAGE - $34.625 \%$

FREQUENCY - $80 \%$

DECIDUOUS FOREST - $R O W$ RESEARCH PROJECT - MICHIGAN - GAS -

RESEARCH INSTITUIE/ARGONNE NATIONAL LABORATORY - Project Manager

STANLEY D. ZELLMER - Plant Ecologists JAMES R. RASTORFER and

GERRIT D. VAN DYKE - Computer Programmer JUDITH B. RASTORFER

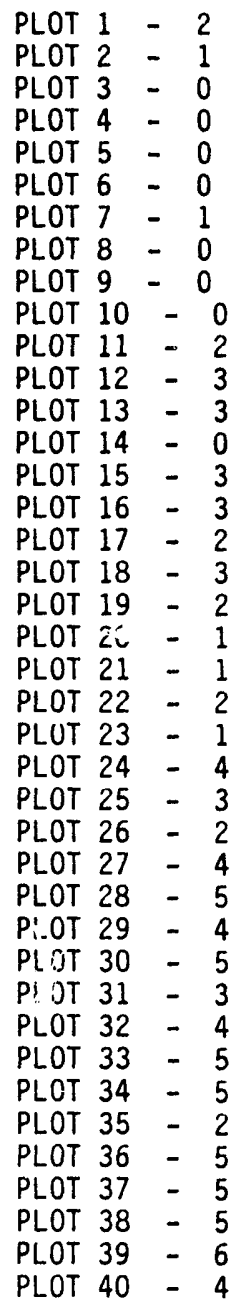




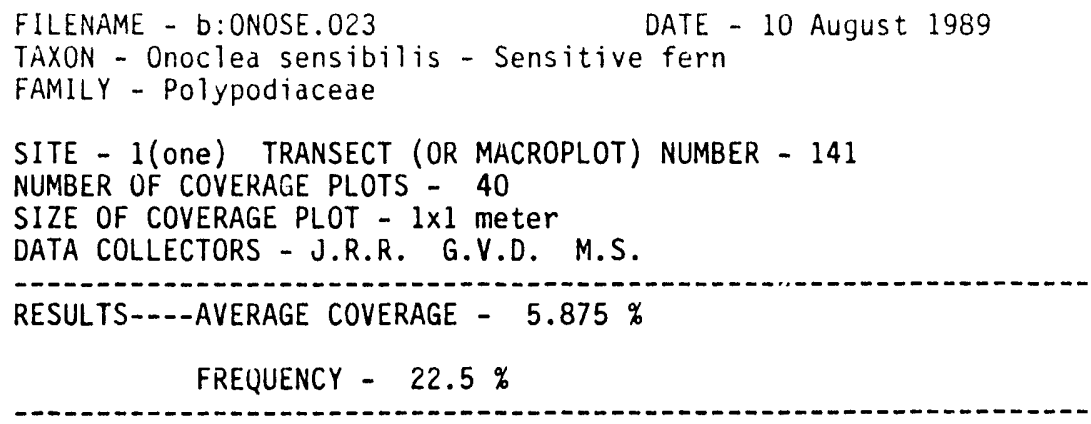

DECIDUOUS FOREST - R 0 W RESEARCH PROJECT - MICHIGAN - GAS RESEARCH INSTITUTE/ARGONNE NATIONAL LABORATORY - Project Manager STANLEY D. ZELLMER - Plant Ecolosists JAMES R. RASTORFER and GFr.RIT D. VAN DYKE - Computer Programmer JUDITH B. RASTORFER

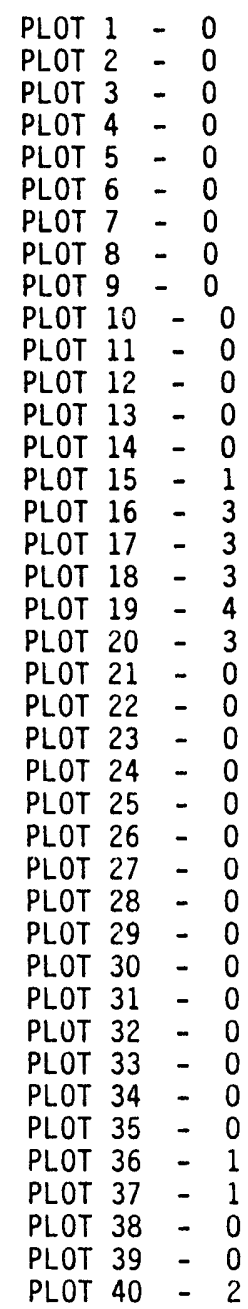



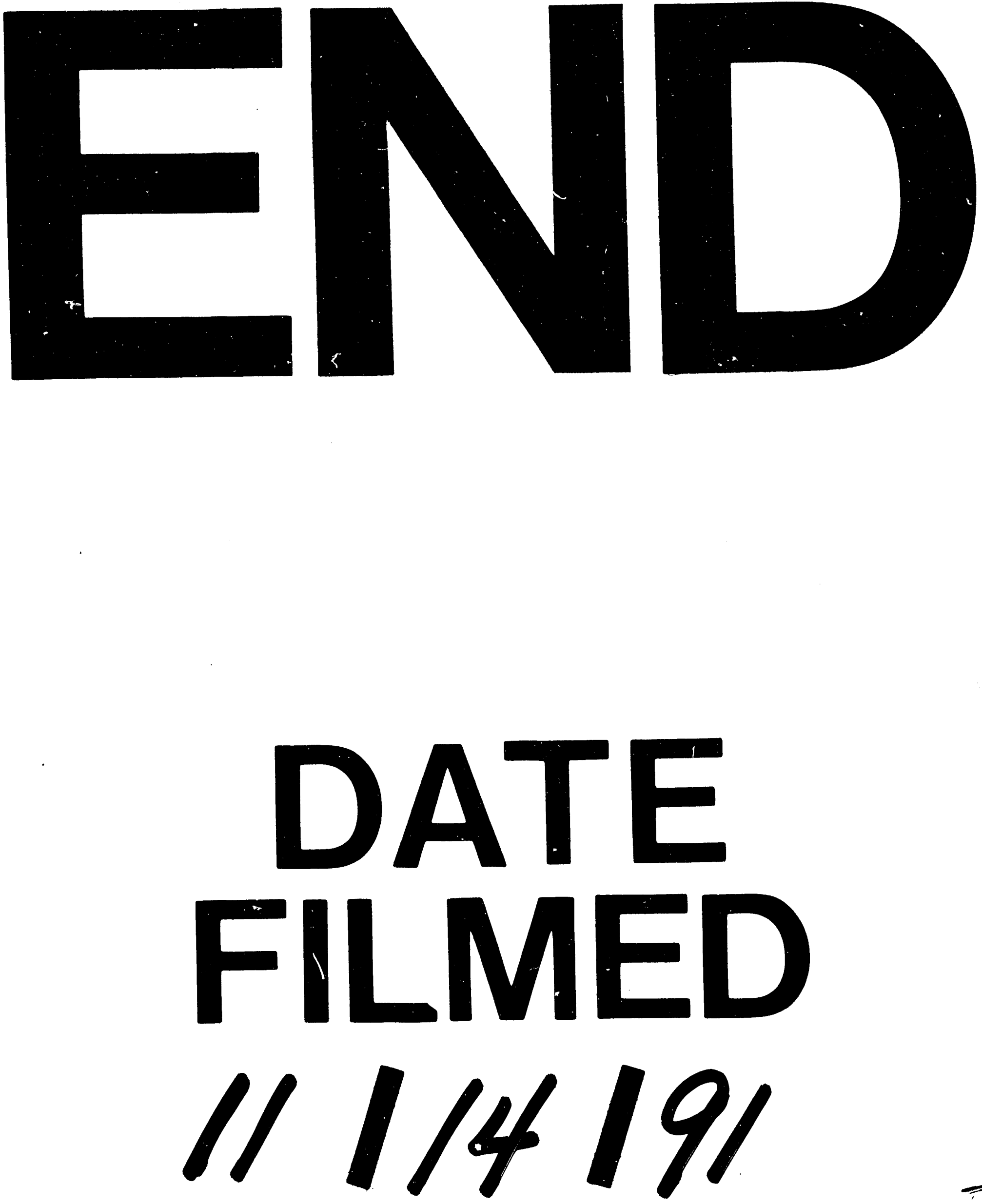

II 
